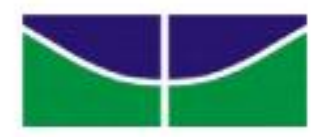

Universidade de Brasília - UnB Instituto de Ciência Política - IPOL

Programa de Mestrado em Ciência Política

\title{
A INFLUÊNCIA DAS POLÍTICAS PÚBLICAS NA CONSTRUÇÃO DAS IDENTIDADES DE POPULAÇÕES TRADICIONAIS E INDÍGENAS
}

VINÍCIUS VIEIRA DE SOUZA

Mestrando em Ciência Política

Universidade de Brasília

Brasília, 2015

UNIVERSIDADE DE BRASÍLIA 
INSTITUTO DE CIÊNCIA POLÍTICA

A INFLUÊNCIA DAS POLÍTICAS PÚBLICAS NA CONSTRUÇÃo DAS IDENTIDADES DE POPULAÇÕES TRADICIONAIS E INDÍGENAS

Autor: Vinícius Vieira de Souza

Brasília, 2015

UNIVERSIDADE DE BRASÍLIA 
INSTITUTO DE CIÊNCIA POLÍTICA

\section{A INFLUÊNCIA DAS POLÍTICAS PÚBLICAS NA CONSTRUÇÃo DAS IDENTIDADES DE POPULAÇÕES TRADICIONAIS E INDÍGENAS}

Vinícius Vieira de Souza

Dissertação apresentada ao Instituto de Ciência Política da Universidade de Brasília - UNB como parte dos requisitos para obtenção do título de Mestre

Brasília, dezembro de 2015

UNIVERSIDADE DE BRASÍLIA 
INSTITUTO DE CIÊNCIA POLÍTICA

PROGRAMA DE PÓS-GRADUAÇÃO EM CIÊNCIA POLÍTICA

DISSERTAÇÃO DE MESTRADO

\section{A INFLUÊNCIA DAS POLÍTICAS PÚBLICAS NA CONSTRUÇÃO DAS IDENTIDADES DE POPULAÇÕES TRADICIONAIS E INDÍGENAS}

Autor: Vinícius Vieira de Souza

Orientador: Prof. Dr. Paulo César Nascimento

Banca:

Prof. Dr. Paulo César Nascimento

Prof $^{\mathrm{a}}$. Dr ${ }^{\mathrm{a}}$. Marilde Loiola de Menezes

Prof. Dr. Martin Adamec 


\section{AGRADECIMENTOS}

Agradeço sobretudo ao meu orientador, Prof. Paulo Nascimento, quem, com sabedoria e serenidade guiou meus passos ao longo deste mestrado e na elaboração do presente trabalho, exercendo orientação fundamental desde a concepção inicial do mesmo, até sua conclusão.

Aos demais professos do IPOL-UNB, que abriram meus caminhos para o mundo da Ciência Política, ampliando sobremaneira minha visão de mundo e meus horizontes, presto também minhas homenagens.

Aos colegas de trabalho, da Advocacia-Geral da União-AGU e do Instituto Chico Mendes de Conservação da Biodiersidade-ICMBio, que, direta ou indiretamente, contribuíram para o resultado final desta dissertação, faço aqui o reconhecimento de sua imprescindibilidade.

Por fim, aos companheiros da vida, que sempre estiveram ao meu lado, minha família (onde incluo Charlie e Nina), Tati, amigos, colegas... muito obrigado! 


\section{RESUMO}

RESUMO: Desde a criação no Brasil das primeiras Unidades de Conservação voltadas para a exploração sustentável dos recursos naturais e desenvolvimento de comunidades tradicionais, tem-se observado com frequência a ressurgência dentre elas de grupos Indígenas que pleiteiam seu reconhecimento pelo Estado e os direitos associados à categoria indígena. $\mathrm{O}$ surgimento de tais casos coincide com a evidência da distinção de tratamento reservado pelo Estado às populações tradicionais e indígenas. Diante deste quadro, a revisão bibliográfica das teorias que tratam das identidades auxiliam na associação entre os dois aspectos, em especial apontando o papel das políticas públicas na construção das identidades étnicas daquelas populações

Palavras-Chave: Unidades de Conservação. Comunidades Tradicionais. Indígenas. Reconhecimento. Políticas Públicas. Identidades Étnicas. 


\begin{abstract}
ABSTRACT: Since the implementation in Brasil of the first Protected Areas with the objetctive of promoting sustainable use of natural resources and development of local peoples it is getting common the emergence among the last of claims toward the State for recognition of their indigenous identity. The appearance of those cases coincide in time with de evidence of the distinctive threatment by the State toward indigenous and non-indigenous people. Taking it in account, the reviewing of the literature on identity provide an explanation of the association between both aspects, specially highlighting the role of public policies in the construction of the ethnic identities of those peoples.
\end{abstract}

Keywords: Protected Areas. Local peoples. Indigenous. Recognition. Public Policies. Ethnic Identities. 


\section{SUMÁRIO}

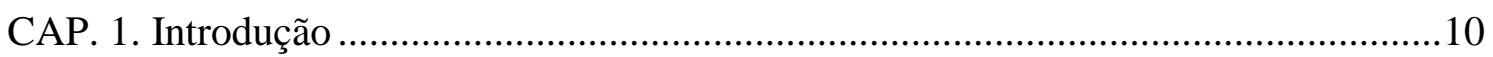

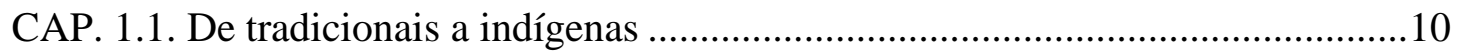

CAP. 1.2. Sobreposições entre Terras Indígenas e Unidades de Conservação..............15

CAP. 1.3. Metodologia e Estrutura........................................................................19

CAP. 2. Quem são eles? .........................................................................................23

CAP. 2.1. O Despertar da Consciência das Populações Tradicionais e a criação das

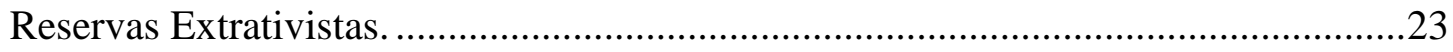

CAP. 2.1.1. O reconhecimento das Populações Tradicionais pelo Ordenamento

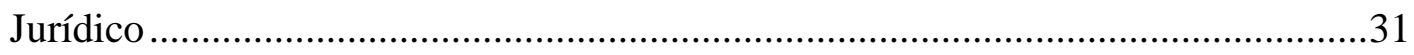

CAP. 2.2. Os Indígenas na Perspectiva do Estado Brasileiro .........................................36

CAP. 2.3. Reservas Extrativistas x Terras Indígenas ……………………………......41

CAP. 3. A Questão da Identidade Étinica ……………………………………….......51

CAP. 3.1. Primordialismo, Instrumentalismo, Construtivismo ...................................58

CAP. 3.2. A evolução do conceito de etnia no Brasil e o tratamento da questão étnica pelo Estado brasileiro............................................................................................72

CAP. 4. Mobilidade Identitária.................................................................................76

CAP. 4.1. A Teoria da Privação Relativa (Relative Deprivation Theory) ....................82

CAP. 4.1. Reconhecimento x Redistribuição e a Territorialização das Identidades ...88

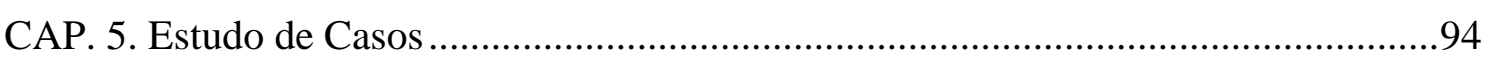

CAP. 5.1. Reserva Extrativista do Alto Juruá e a Terra Indígena Arara do Rio Amônia

CAP. 5.2. Os Kuntanawa no Alto Juruá ……………………………………….......103

CAP. 5.3. Reserva de Desenvolvimento Sustentável Mamirauá e T.I. Porto Praia ..108

CAP. 5.4. Floresta Nacional de Tapajós e os Taquara ………………………..........113

CAP. 5.5. Reserva de Desenvolvimento Sustentável Amanã e Comunidade Ebenézer

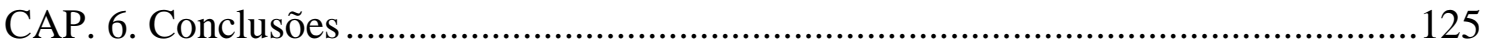

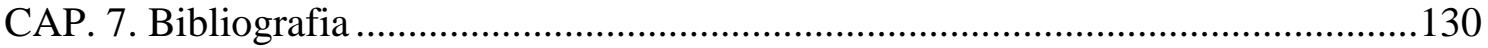




\section{Lista de Siglas}

FUNAI. Fundação Nacional do Índio

IBAMA. Instituto Brasileiro do Meio Ambiente e dos Recursos Naturais Renováveis

ICMBio. Ínstituto Chico Mendes de Conservação da Biodiversidade

OIT. Organização Internacional do Trabalho

PEC. Proposta de Emenda Constitucional

SNUC. Sistema Nacional de Unidades de Conservação

SPI. Serviço de Proteção aos Índios

RCID. Relatório Circunstanciado dos Estudos de Identificação e Delimitação

RDS. Reserva de Desenvolvimento Sustentável

RESEX. Reserva Extrativista

STF. Supremo Tribunal Federal

TI. Terra Indígena 


\section{Cap. 1. Introdução}

\subsection{De tradicionais a indígenas}

"Porque somos plantas e raíz desta terra"1

Aos 04 de junho de 2013 os meios de comunicação de todo o Brasil noticiavam mais um conflito envolvendo demarcação de Terra Indígena ${ }^{2}$, desta vez no Estado do Acre, dando conta da ocupação da escola municipal de Marechal Thaumaturgo pelo grupo Apolima-Arara, reclamante da terra prometida pela "Constituição Cidadã”.

Conforme declaravam, buscavam os Apolima com o ato pressionar a Fundação Nacional do Índio-Funai a, concluindo o processo demarcatório, promover a extrusão dos "não-indígenas" residentes na área, dando cabo à concretização da Terra Indígena Arara do Rio Amônia.

O que chamava a atenção no caso, entretanto, era o fato de que a pleiteada extrusão consistiria na realocação, justamente, de parte da população tradicional seringalista que 25 anos antes reivindicara, sob a liderança de Chico Mendes, a criação da primeira Reserva Extrativista do país, a emblemática Resex do Alto Juruá, à qual a nova Terra Indígena viria a se sobrepor.

A par da linha da descendência direta de grupos nativos que historicamente ocupavam a região, os Apolima-Arara congregavam pelo menos dois outros ramos, bem identificados por estudos antropológicos realizados sobre a região: de um deles traziam a herança de indivíduos que nas décadas anteriores haviam declarado-se "nãoindígenas" por ocasião da demarcação das Terras vizinhas, tendo delas migrado em

\footnotetext{
${ }^{1}$ Trecho da missiva enviada pela ASAREAJ “aos órgãos competentes”, 15/05/2011.

2 Notícia consultada em 12/11/2015, veiculada no link: http://g1.globo.com/ac/acre/noticia/2013/06/indios-invadem-escola-em-marechal-thaumaturgo.html
} 
direção à margem oposta do Rio Juruá, onde se localizava a Resex ${ }^{3}$. De outro, originavam do mesmo grupo extrativista, população tradicional ${ }^{4}$ contra a qual então confrontavam, tendo ora passado a se autoidentificar como indígenas.

O que estaria levando aquela população que poucos anos antes não se reconhecia como silvícola, e havia estado à frente do movimento seringalista que culminara na criação da Reserva a ora buscar "sua ancestralidade indígena para requerer terras próprias" $"$ ?

Divididos pela categorização "indígenas" e "não-indígenas", passariam os moradores da região do Alto Juruá do histórico convívio ao embate ${ }^{6}$, levando a entidade gestora da Reserva Extrativista a proferir a acusação: “o grupo indígena, que pleiteia hoje o território que tradicionalmente é ocupado pelas populações tradicionais é de organização recente e nem sempre esteve presente na área, requerendo o território com objetivo de acesso à política social indigenista"?

Com efeito, o pleito pelo reconhecimento de uma identidade singular somava-se a históricas demandas por melhores condições de vida: o direito a terra, programas

\footnotetext{
${ }^{3}$ A maior parte daqueles individuos recebera, inclusive, a indenização prevista em lei ao final do regular processo de extrusão, quando da demarcação da Terra Indígena Kampa. Outros, também saídos da mesma Terra Indígena, haviam sido identificados pela Funai como "Kampas não-tradicionais", reconhecidos, assim como indígenas, mas não se confundindo com os demais Kampas, tendo sido considerados, para todos os efeitos, beneficiários daquela terra indígena.
}

${ }^{4}$ Embora a expressão população tradicional tenha abrangência suficiente para englobar também as populações indígenas, o uso do termo tem sido usado também, de forma estrita, para se referir às populações culturalmente diferenciadas, que vivem sob modo de produção tradicional, em bases sustentáveis, neste sentido constando em diversas normas no ordenamento jurídico brasileiro.

${ }^{5}$ Nota Técnica n ${ }^{\circ}$ 41/11 - CGCOT/DIUSP/ICMBio, produzida oficialmente pelo Instituto Chico Mendes de Conservação da Biodiversidade.

${ }^{6}$ Desde a notícia citada, datada de 06/2013, inúmeros outros conflitos tiveram lugar na região, conforme se vê da seguinte notícia, datada de maio de 2015, veiculada no seguinte site, conforme consutla realizada em 12/11/2015: http://g1.globo.com/ac/acre/noticia/2014/05/indios-ocupam-predio-da-funai-no-interiordo-acre.html

${ }^{7}$ Extraído do documento intitulado "Plano de Ação para dupla afetação da área sobreposta entre a Terra Indígena Arara do Rio Amônia e a Reserva Extrativista Alto Juruá". No mesmo sentido a Nota Técnica $n^{\circ}$ 41/11 - CGCOT/DIUSP/ICMBio, relatava:

“(...) a região da Unidade que fica sobreposta ao novo território indígena é ocupada há pelo menos cem anos por uma população majoritariamente não indígena. As poucas famílias indígenas que ai residem vieram para a área em função de um conflito com outras populações indígenas quando da delimitação da terra indígena Ashaninka do rio Amônia. Quanto aos processo de construção identitária, exemplifica o caso da família de seu Milton, na bacia do rio Tejo, seringueiros à época da criação da Reserva e assim até poucos anos, que buscou sua ancestralidade indígena para requerer suas próprias terras e inclusão na política social indigenista do governo federal". 
próprios de saúde, acesso a crédito, educação, e, sobretudo, autonomia na gestão de suas áreas, fazendo emergir a denúncia da vantajosidade do regime jurídico das Terras Indígenas, vis-a-vis ao das Reservas Extrativistas, destinado às populações tradicionais, contexto que serviria de palco nos anos seguintes, em diversas outras Resex por todo o país, para a emergência de iguais demandas por reconhecimento de identidade indígena.

O descompasso entre os direitos reservados a uma e a outra categoria de terras, que viria à tona nos anos recentes, encontrava origem, em parte, nos eventos situados na década de 80, especialmente quando, a somar forças ao discurso social, apropriou-se o movimento extrativista de argumentos de ordem ambiental, aliando a sustentabilidade das comunidades tradicionais à conservação da natureza. A associação teria ressonância mais tarde na edição do Decreto 98.897/90, que criou a figura das "Reservas Extrativistas" no ordenamento jurídico pátrio, ali definindo-as como "espaços territoriais destinados à exploração autossustentável e conservação dos recursos naturais renováveis, por população extrativista" ${ }^{8}$. Dez anos mais tarde, com a edição da Lei 9.985/00, que criou o Sistema Nacional de Unidades de Conservação, as Resex restariam, de forma definitiva, inseridas dentre as "unidades de conservação de uso sustentável”, com o objetivo básico de "compatibilizar a conservação da natureza com o uso sustentável de parcela dos seus recursos naturais".

A circunstância foi elucidada por Lobão (2006, p. 37), em monografia que assim contextualizava:

"[Após a ECO92] uma nova direção havia sido indicada: as reservas extrativistas estavam sendo subsumidas no universo semântico do conservacionismo ambiental. A consolidação dessa resultante teve como marco a promulgação do SNUC [Sistema Nacional de Unidades de Conservação]. Nele as reservas extrativistas ficaram submetidas ao conservacionsimo, perdendo grande parte da sua ênfase original na proteção e direitos sociais. Afinal, de Unidades de Conservação de Interesse Ecológico e Social, as Resex passaram a ser Unidades de Conservação do Desenvolvimento Sustentável. O que poderia ser uma diferença sutil transformou-se em determinante para o enredamento da política pública em um universo totalmente distinto ${ }^{10}$.

Tal discrepância levaria autores como REZENDE (2002, p. 47) a afirmar que, "nesta leitura da transformação do projeto das Reservas Extrativistas, não é de se

\footnotetext{
${ }^{8}$ BRASIL, Decreto 98.897/90, de 30 de janeiro de 1990, art. $1^{\circ}$.

${ }^{9}$ Brasil. Lei $9985 / 00$, de 18 de julho de 2000 , art. $7^{\circ}, \S 2^{\circ}$

${ }^{10}$ LOBÃO. Ronaldo Joaquim da Silveira. Cosmologias Políticas do Neocolonialismo: como uma política pública pode se transformar em uma política do Ressentimento. Tese de Doutorado apresentada ao Programa de Pós-Graduação em Antropologia Social da UNB. 2006, p. 372006, p. 37
} 
estranhar que Terras Indígenas sejam uma alternativa a contextos nos quais a falta de autonomia tenha levado os modos de vida dos povos tradicionais a situações de ameaça de transformação forçada ou mesmo de desaparecimento"11.

Mais do que isto, as críticas lançariam luz sobre a vinculação entre o reconhecimento étnico e o acesso a políticas públicas de caráter econômico-social, em um exemplo do que viria a ser denominado "territorialização da identidade"12, em que demandas por reconhecimento e por redistribuição teriam uma matriz comum: a necessidade de auto identificação em uma das categorias propostas pelo Estado.

A replicação de episódios semelhantes por todo o país, bem como as críticas e suspeitas que se ergueriam em face de cada nova terra indígena declarada conduziriam à questão: em que medida os pedidos recentes de reconhecimento miravam preponderantemente em políticas redistributivas, inseparáveis, por força do modelo atual, do autorreconhecimento como indígena? Seriam os mesmos pleitos observáveis caso Terras Indígenas e Reservas Extrativistas oferecessem a seus moradores iguais direitos econômicos e sociais?

A partir das observações formulou-se a hipótese ora posta à prova de que a imposição de categorias identitárias rígidas, associadas a políticas territoriais, sociais e econômicas, constituir-se-ia em incentivo para que grupos se reconhecessem como membros daquelas categorias mais vantajosas, impondo segregações e potencializando os conflitos locais. Ou conforme visão compartilhada por FREEMAN (2005, p. 01), a

\footnotetext{
${ }^{11}$ REZENDE, Roberto Sanches. Gestão de Conflitos Territoriais Relacionados a Sobreposições de Terras Indígenas em Reservas Extrativistas na Amazômia (produto IV) Projeto PNUD BRA/08/002 - Gestão de Reservas Extrativistas federais da Amazônia Brasileira. Pg, 47.

${ }^{12}$ O conceito é assim explicitado por Renato Athias, citando OLIVEIRA (1999):

Neste sentido, tanto para os grupos indígenas quanto para as terras quilombolas, hoje já em processo de identificação e demarcação relacionada à política existente de reconhecimento oficial das "terras de negros", a identidade étnica está associada à noção de territorialização é definida como um "processo de reorganização social que implica: i) a criação de uma nova unidade sociocultural mediante ao estabelecimento de uma identidade étnica diferenciadora; ii) a constituição de mecanismos políticos especializados; iii) a redefinição do controle social sobre os recursos ambientais e iv) a reelaboração da cultura e da relação com o passado". OLIVEIRA, João Pacheco, Uma Etnologia dos Índios "Misturados"? Situação Colonial, Territorialização e Fluxos Culturais. In: OLIVEIRA, João Pacheco A Viagem da Volta. ContraCapa, Rio de Janeiro, 1999 p.18. in ATHIAS, Renato. A noção de identidade étnica na antropologia brasileira. De Roquette Pinto a Roberto Cardoso de Oliveira. Editora Universitária UFPE. Recife, PE. 2007. $\mathrm{Pg}, 20$.
} 
etnicidade proveria os mecanismos para os grupos e líderes políticos se mobilizarem na busca de seus interesses comuns, em uma comoção que teria como pano de fundo a privação de recursos ${ }^{13}$.

A interpretação dos fenômenos ora trazidos a lume perpassa, destarte, pela compreensão dos conceitos de etnicidade e identidade étnica, sobre os quais disputam teóricos primordialistas e circunstancialitas; pelo estudo dos contornos das políticas públicas destinadas a um e outro grupo; pela forma como as identidades são construídas e reconformadas, bem como pela investigação de casos concretos de comunidades indígenas emergidas no seio de populações antes percebidas tão-somente como tradicionais, elementos que compõem abaixo a presente dissertação.

\footnotetext{
${ }^{13}$ FREEMAN, Diane. An Explanation of Conflict: Ethnicity, Deprivation, and Rationalization. Kentucky Political Science Association Conference. 2015. Pág. 01.
} 


\subsection{Sobreposições entre Terras Indígenas e Unidades de Conservação}

Em março de 2009 o Supremo Tribunal Federal concluia o histórico julgamento do mérito da Petição $3388^{14}$, amplamente divulgado pela mídia, que tratava da sobreposição entre a Terra Indígena Raposa Serra do Sol e o Parque Nacional do Monte Roraima, no extremo norte do país. O decisium, que adotando técnica inovadora extrapolaria a discussão do caso concreto, repercutiria na atuação do Estado em outros casos de sobreposição pelo país, tornando-se importante paradigma sobre a matéria.

Em síntese, enfrentava a Corte questão atinente a qual das áreas deveria preponderar no caso de compartilharem o mesmo espaço geográfico, se a Terra Indígena ou a Unidade de Conservação. A coincidência territorial encontrava explicação histórica: mantidas conservadas pelos povos indígenas, avultam suas áreas em relevância para a biodiversidade, chamando a atenção do Estado para a necessidade de criação ali de espaços ambientalmente protegidos, as Unidades de Conservação. Em casos mais raros, a dinâmica se daria em sentido inverso: carentes de terras, os povos indígenas se deslocariam justamente para aqueles remanescentes de áreas protegidas, imprimindo sobre elas um sentido de retomada. O resultado, em ambas as hipóteses, seria idêntico: dois interesses públicos sobrepostos e, ainda que fruto de uma interpretação literal, aparentemente conflitantes.

Igualmente, ambos os valores coincidiriam em possuir matriz constitucional, a proteção aos indígenas por força do mandamento do art. 231, e a da biodiversidade com fulcro no art. 225 da atual Constituição Federal, que assim prescrevem:

Art. 231. São reconhecidos aos índios sua organização social, costumes, línguas, crenças e tradições, e os direitos originários sobre as terras que tradicionalmente ocupam, competindo à União demarcá-las, proteger e fazer respeitar todos os seus bens. (grifos nossos)

$14 \mathrm{O}$ andamento completo do processo judicial pode ser verificado em: http://stf.jusbrasil.com.br/jurisprudencia/3817597/peticao-pet-3388citar os embargos (consulta realizada em 16/11/2012). Cumpre esclarecer que após o julgamento do mérito da ação foi interposto recurso de embargos de declaração, que esclareceu e eliminou contradições e obscuridades em pontos específicos do julgado. 
$\S 1^{\circ}$ São terras tradicionalmente ocupadas pelos índios as por eles habitadas em caráter permanente, as utilizadas para suas atividades produtivas, as imprescindíveis à preservação dos recursos ambientais necessários a seu bem-estar e as necessárias a sua reprodução física e cultural, segundo seus usos, costumes e tradições.

$\S 2^{\circ}$ As terras tradicionalmente ocupadas pelos índios destinam-se a sua posse permanente, cabendo-lhes o usufruto exclusivo das riquezas do solo, dos rios e dos lagos nelas existentes. ${ }^{15}$

Art. 225. Todos têm direito ao meio ambiente ecologicamente equilibrado, bem de uso comum do povo e essencial à sadia qualidade de vida, impondo-se ao Poder Público e à coletividade o dever de defendê-lo e preservá- lo para as presentes e futuras gerações.

$\S 1^{\circ}$ Para assegurar a efetividade desse direito, incumbe ao Poder Público:

(...)

III - definir, em todas as unidades da Federação, espaços territoriais e seus componentes a serem especialmente protegidos, sendo a alteração e a supressão permitidas somente através de lei, vedada qualquer utilização que comprometa a integridade dos atributos que justifiquem sua proteção; (Regulamento) ${ }^{16}$ (grifei)

Se de um lado a própria Constituição destacava o usufruto exclusivo pelos índios de suas Terras Indígenas, de outro também a Lei que veio a regulamentar a Constituição em matéria de Unidades de Conservação previu dois grandes grupos de Unidades, chamados de Proteção Integral e Uso Sustentável, não sendo permitido no interior das primeiras o uso direto de seus recursos e sua consequente ocupação. Assim se dava com os Parques Nacionais, o que acarretara o enfrentamento da questão pela Corte Constitucional no episódio da Raposa.

De forma concilitatória, a contenda foi naquela oportunidade decidida pelo Supremo Tribunal Federal pelo reconhecimento da possibilidade de dupla afetação da área, i.e., a destinação da relevante porção territorial a ambos os objetivos, ainda que a conclusão resultasse na mitigação de ambos dispositivos constitucionais.

As disputas sobre áreas sobrepostas não restariam, entretanto, pacificadas, especialmente por não ter o leading case tratado da peculiar realidade atinente às sobreposições entre Terras Indígenas e Unidades de Conservação do tipo uso sustentável. Se de um lado nas sobreposições com Unidades de proteção integral como os Parques - gerava tensão a impossibilidade legal de ocupação e uso da área protegida pelos indígenas, nas sobreposições com Unidades do tipo uso sustentável, onde tal óbice não existia, problematizava o fato de já serem elas habitadas por outros

\footnotetext{
${ }^{15}$ Brasil. Constituição Federal, de 05 de outubro de 1988, art. $231 \S 1^{\circ}$.

${ }^{16}$ Brasil. Constituição Federal, de 05 de outubro de 1988, art. 225, III, $\S 1^{\text {o }}$.
} 
atores, beneficiários das Unidades de Conservação, o que relativizaria, fatalmente, a exclusividade indígena sobre as terras.

Em muitos dos conflitos notados nos anos que seguiram, a pacifica convivência entre indígenas e demais comunidades tradicionais penderia para o conflito pela simples defesa pelos indígenas do conteúdo da expressão exclusividade, então descoberta no bojo da Constituição Federal, em geral ante a atuação da Fundação Nacional do Índio em seu dever de extrusão dos "não-indígenas" ao final de cada processo demarcatório. ${ }^{17}$

A exclusividade das terras, bem como outros direitos reservados aos indígenas seria também percebida pelas próprias comunidades tradicionais, pulverizando-se dentre elas demandas por reconhecimento como indígenas, colocando a questão étnica no centro dos conflitos por terras nas mais isoladas localidades do Brasil, representando uma evolução do problema das sobreposições em Unidades de Proteção Integral para as do tipo Uso Sustentável:

"Para além dos Parques, boa parte dos conflitos mais recentes de sobreposição decorrem da demarcação de TIs em UCs de Uso Sustentável. Nessas unidades, o lastro de desentendimentos das comunidades residentes (ou usuárias) com representantes locais dos órgãos ambientais, bem como a consolidação dos direitos indígenas, têm estimulado alguns grupos a reivindicarem o reconhecimento oficial de identidade indígena. Os problemas surgem quando a demarcação de TI em área incidente à UC em questão acaba por restringir o acesso de outras comunidades (que não se reconhecem como indígenas) aos recursos naturais da área"18.

Se o atual estágio remete a conflitos e pessimismos no convívio entre populações indígenas e tradicionais no país, o passado recente ecoa origens comuns, além de capítulos de união em prol de objetivos comuns.

\footnotetext{
${ }^{17}$ Neste sentido, afirmava Fany:

"sobreposições envolvendo territórios de povos indígenas e tradicionais não indígenas adentram o "terreno minado" da "medida da tradicionalidade", gerando "boa parte dos conflitos mais recentes de sobreposição". Para elas, a maioria desses conflitos ocorre por "restringir o acesso de outras comunidades (que não se reconhecem como indígenas) aos recursos naturais da área" RICARDO, Fany (org.). Terras Indígenas \& Unidades de Conservação da natureza: o desafio das sobreposições. São Paulo: Instituto Socioambiental. 2004. Pg. 9. Citado por REZENDE, Roberto Sanches \& POSTIGO, Augusto. Reconhecimentos Territoriais e Desconhecimentos Institucionais. Revista do Centro de Estudos Rurais - UNICAMP 2013. São Paulo. V. 7, n2, pg 135).
}

18 RICARDO, Fany (org.). Terras Indígenas \& Unidades de Conservação da natureza: o desafio das sobreposições. São Paulo: Instituto Socioambiental. 2004. Pg. 592. 
É o que se depreende da investigação dos casos trazidos à lume, que revelam além de imbricada proveniência e interação entre populações tradicionais e indígenas, $o$ semelhante anseio por melhores condições de vida.

Na busca, assim, por ampliar a compreensão sobre o fenômeno, adotou-se a metodologia abaixo explicitada, que combina o olhar focado em casos específicos de sobreposição entre Terras Indígenas e Unidades de Conservação de Uso Sustentável, bem como as principais teorias que tentam interpretá-los. 


\subsection{Metodologia e Estrutura}

A tentativa da Suprema Corte de pacificar o emblemático caso da Terra Indígena Raposa Serra do Sol por meio de julgado abrangente e dotado de abstração, que pudesse, destarte, ser aplicado a outras situações análogas, tinha em conta um dado significativo. Segundo levantamento realizado pelo Instituto Sócio Ambiental-ISA em 2004 - anteriormente, assim, à prolação do decisium -, haveria em todo o país 55 casos de sobreposição entre Unidades de Conservação e Terras Indígenas, correspondente a uma área total de 12.941 .061 hectares $^{19}$.

Daquele quantitativo 24 ocorreriam em Unidades de Proteção Integral, enquanto 31 sobreposições teriam lugar entre Unidades de Uso Sustentável ${ }^{20}$.

Interessa para o objeto do presente estudo não toda e qualquer sobreposição, já que aqui se tem foco nos pleitos por reconhecimento de grupos indígenas emergidos dentre comunidades tradicionais já beneficiadas com áreas próprias, i.e., o movimento identitário das populações tradicionais rumo à autoidentificação como indígena. Faz-se, assim referência a apenas 3 tipos específicos de Unidades de Conservação de Uso Sustentável, que, tipicamente, abrigam populações tradicionais: as Reservas Extrativistas, Reservas de Desenvolvimento Sustentável - que muito se assemelham às primeiras - e as Florestas Nacionais, categoria que admite a permanência de populações que ali já residissem no momento de sua criação, hipótese em que também muito se assemelhará, na porção ocupada, à Reserva Extrativista. De acordo com aquela mesma fonte, restariam, assim, 28 casos de sobreposição de Terras Indígenas e Unidades das 3 categorias cima apontadas.

Por outro lado, há de se considerar de interesse casos de potenciais sobreposições, entre Unidades já criadas e Terras não demarcadas, número que variará

${ }^{19}$ RICARDO, Fany (org.). Terras Indígenas \& Unidades de Conservação da natureza: o desafio das sobreposições. São Paulo: Instituto Socioambiental. 2004. Pg. 592.

${ }^{20}$ Ibidem, pg. 592. Embora o texto fale em 23 sobreposiçoes com UCs de Proteçao integral, 31 com Ucs de Uso sustentável e 1 com tripla sobreposição, englobamos esta última dentre aquelas de Proteção Integral para os fins aqui estudados, uma vez que vale para ela o regime da UC de maior proteção. 
com o tempo, tendo em vista a abertura de novos processos no âmbito da Funai, em regra com caráter sigiloso, que podem ou não dar cabo à criação de Terras Indígenas.

Lado outro, há de se excluir daquele universo sobreposições territoriais onde convivam grupos indígenas e populações tradicionais bem definidos, que não digam respeito à hipótese aqui tratada de tradicionais que passaram a se identificar como índios em um momento especifico no tempo.

Em estudo encomendado pelo Instituto Chico Mendes-ICMBio, entidade que se ocupa da gestão das Unidades de Conservação federais, por exemplo, foram identificadas de pronto 21 Unidades com potenciais conflitos sociais na região amazônica, algumas delas envolvendo sobreposições de interesses indígenas e de populações tradicionais.

Diante dos objetivos do presente trabalho, decidiu-se selecionar cinco casos ilustrativos nos quais se evidenciasse a apresentação de pedidos recentes de reconhecimento indígena perante a Funai, envolvendo populações tradicionais já beneficiários de Unidades de Conservação. Com fulcro neles, constitui a proposta demonstrar de que modo a evolução das teorias acerca das identidades étnicas vem apresentar explicação para tal movimento de ressurgência identitária com base em estímulos do meio, sejam econômicos ou sociais, e em especial aqueles decorrentes da ação do Estado.

Não se trata, portanto, de escolha aleatória, que teria o escopo de inferir a relação de causalidade entre o autorreconhecimento indígena e a ampliação de direitos de cunho econômico-social. Ao contrário, consiste o trabalho em esforço de investigação e aprofundamento sobre casos concretos específicos em que o autorreconhecimento se deu de forma inovadora, entre comunidades que até passado recente não se percebiam como indígenas, e em contexto específico em que o reconhecimento pelo Estado acarretaria vantagens objetivas para tais populações, satisfazendo demandas ou pondo fim a conflitos. À descrição somar-se-ão, assim, as contribuição de cunho teórico, que tratam das transformações identitárias tendo em conta o meio circundante, que coincidem com a dinâmica relatada naqueles casos.

Neste sentido, elegeu-se os seguintes casos para descrição: 1) Terra Indígena Apolima-Arara; 2) Terra Indígena Kuntanawa, ambas sobrepostas à Reserva Extrativista 
do Alto Juruá; 3) Terra Indígena Porto-Praia, sobreposta à Reserva de Desenvolvimento Sustentavel Mamirauá; 4) Terra Indígena Takuna, sobreposta à Floresta Nacional de Tapajós; 5) Comunidade Ebenézer, inserida nos limites da Reserva de Desenvolvimento Sustentável de Amanã.

A justificativa para o presente trabalho, encontra-se na baixa compreensão geral do tema, seja pela sociedade, seja pelos agentes estatais encarregados das decisões relacionadas àqueles destinatários, motor de preconceitos e prejuízos, muito embora o trato científico da matéria já se encontre em estágio significativamente esclarecedor, conforme abaixo restará nítido.

Neste sentido estruturar-se-á o trabalho da seguinte maneira:

a) Preliminarmente, imperioso traçar, ante a equivocidade do termo, quem são as chamadas populações tradicionais, enquanto tipo sociológico, a seus olhos, aos olhos do Estado, e para fins deste estudo;

b) da mesma forma, tendo em conta também ser termo objeto de disputas, far-se-á breve análise do conceito de indígena, adotado sobretudo pelo Estado para fins de criação de Terras Indígenas e concessão dos demais benefícios associados.

c) em seguida, na esteira da especificação de quem são aquelas coletividades, voltará a pesquisa para a comparação dos regimes jurídicos de direitos reservados a um e outro, mirando, sobretudo, no destaque da disparidade entre eles.

d) na sequência, avançando-se sobre o marco teórico, faz-se digressão sobre as teorias que, em evolução, buscaram explicar as identidades e seus fenômenos relacionados, como o nacionalismo, identidades étnicas e nacionais;

e) complementarmente, tópico específico abordará de forma sintética o trato da questão étnica no Brasil e as políticas adotadas pelo Estado naquele sentido;

f) os esclarecimentos que a incursão anterior proporcionará sobre o tema permitirá, já neste ponto, tratar de como os grupos externam suas identidades, de maneira a que estas apresentem perfis distintos quando comparadas no tempo;

g) na sequência, apresenta-se a teoria que vem se desenvolvendo acerca dos conflitos interétnicos, denominada relative deprivation theory, que os associa a situações de carência de recursos e políticas discriminatórias pelo Estado, de grande interesse para o presente trabalho; 
h) por fim, de forma complementar, antes de se passar à descrição e análise dos casos concretos, tópico específico tratará da relação entre políticas de reconhecimento e redistribuição do Estado, bem de políticas chamadas assim chamadas de territorialização da identidade;

i) sob as bases fundadas, far-se-á a anunciada incursão sobre os casos concretos;

j) por fim, apresenta-se conclusões.

Inicia-se, assim, conforme esquema acima proposto, apresentando os protagonistas do estudo, populações tradicionais e indígenas. 


\title{
Cap. 2. Quem são eles?
}

\section{Cap. 2.1. O Despertar da Consciência das Populações Tradicionais e a Criação das Reservas Extrativistas}

\begin{abstract}
"No começo pensei que estivesse lutando para salvar seringueiras. Depois pensei que estava lutando para salvar a Floresta Amazônica. Agora percebo que estou lutando pela humanidade",21
\end{abstract}

A história das conscientização das populações tradicionais brasileiras enquanto tipo sociológico próprio, distinto de indígenas e quilombolas, tem início na Amazônia em passado não distante, sendo imperioso, porém, retroceder, brevemente, às origens do povoamento da região Norte, que melhor explicam o caldeirão étnico que a caracteriza, servindo de combustível para os conflitos identitários aqui abordados.

O contato europeu com a região amazônica teve início já nas primeiras navegações à América, quando lendas espanholas e portuguesas em torno do El Dorado - ou El Don del Oro - atrairiam o espanhol Pizón para incursões pelo Rio Amazonas. As entradas portuguesas se dariam tanto pelo rio, quanto por meio de cabotagem pelo litoral dos atuais Estados do Piauí e Maranhão ${ }^{22}$.

Daquele impulso teriam lugar, a partir de 1549, quando da instituição do primeiro Governo-Geral, entradas e bandeiras, bem como missões colonizadoras, aldeamentos e reduções Jesuítas, de forma ainda esporádica ou pontual. É somente a partir do século XVII, entretanto, que portugueses, provenientes de Recife e Salvador, partem em direção à Amazônia com animus de ocupá-la, sobretudo a fim de afastar o interesse de ingleses, holandeses e franceses que faziam incursões pela região em busca das chamadas drogas do sertão, produtos da floresta obtidos através do extrativismo,

\footnotetext{
21 Chico Mendes, em célebre frase. Dentre outras fontes, citada em: http://www.prefeitura.sp.gov.br/cidade/secretarias/meio_ambiente/umapaz/galeria_de_retratos/index.php? $\mathrm{p}=7312$ (consulta realizada em 20/11/2015)

22 GADELHA, Regina Maria A. Fonseca. Conquista e ocupação da Amazônia: a fronteira Norte do Brasil. Estud. av. [online]. 2002, vol.16, n.45, pg 63.
} 
como o guaraná, a baunilha, o cravo, a pimenta, a castanha, o algodão e ervas medicinais $^{23}$, de grande valor na Europa.

Visando a defesa do território, seriam fundadas sob aquele objetivo as cidades de Belém do Pará, Macapá, Manaus e São Luís do Maranhão, que se desenvolveriam a partir da diretriz de Lisboa de se evoluir do simples extrativismo daqueles produtos para o seu cultivo regular ${ }^{24}$.

Atingindo as expectativas portuguesas, alcançaria em especial o Maranhão período de prosperidade entre as décadas de 1790 e 1860, sobretudo pela produção do fumo, arroz e algodão, suprindo de matéria-prima as indústrias inglesas então carentes destes insumos em razão da interrupção do comércio com a colônia americana nos anos que antecederam sua independência e durante a Guerra de Secessão.

O incremento da produção maranhense, por sua vez, demandaria mão-de-obra escrava, a qual seria suprida, em grande parte, por meio da escravização indígena, trazidos de outras partes da Amazônia, em razão do alto preço que os escravos africanos alcançavam no período. As entradas em busca da escravização indígena representariam, igualmente, forte linha de povoamento e miscigenação para a região. Contra elas avançariam também pela Amazônia as missões jesuítas, o que, somado, proporcionaria significativa expansão territorial em favor da metrópole portuguesa.

A partir de 1750 busca Pombal apressar o povoamento da região norte, para isto decretando Leis que isentavam os colonizadores de impostos régios, concediam sesmarias como prêmio, distribuíam gratuitamente instrumentos agrícolas ${ }^{25}$. Em 1755 são instituídas as Companhias-Gerais do Grão-Pará e do Maranhão para coordenar os projetos em marcha, extintas em 1778 pelo fracasso da empreitada. As condições de prosperidade, especialmente no Maranhão, apoiavam-se em anormalidades do mercado mundial, não logrando manterem-se após a regularização do mesmo, o que forçaria a produção a voltar-se para a subsistência no primeiro quartel do século XIX ${ }^{26}$.

\footnotetext{
${ }^{23}$ CARDOSO, Fernando Henrique. Müller, Geraldo. Amazônia: expansão do capitalismo [online]. Rio de Janeiro: Centro Edelstein de Pesquisas Sociais, 2008. Pg. 13. Apanhado histórico do povoamento e seus aspectos econômicos e políticos. ISBç 978-85-99662-73-1

${ }^{24}$ Ibidem, pg. 14.

${ }^{25}$ Ibidem, pg. 14.

${ }^{26}$ FURTADO, Celso. Formação Econômica do Brasil. 24 cd. São Paulo, Editora Nacional. Pg. 93. Edição on-line.
} 
A Grande Seca de $1877^{27}$ na região Nordeste "empurraria" para o interior amazônico milhares de moradores do sertão brasileiro, em uma das maiores correntes migratórias já vivenciadas pelo país até hoje ${ }^{28}$, complexificando o já intrincado mapa etnográfico da região. O fluxo migratório não se dera aleatoriamente, senão em razão da atração exercida pela escalada produtiva do ouro amazônico, como ficou conhecida: a borracha.

O latéx natural começara a ser extraído com fincas à exportação já em 1827, ganhando força a produção a partir de 1840, quando Charles Goodyer criou o processo de vulcanização que permitiu sua utilização como matéria-prima de pneus, para a incipiente indústria automobilística ${ }^{29}$. Como consequência, a exportação do latex saltaria de 156 para 2.673 toneladas entre 1830 e $1860^{30}$. No período compreendido entre 1879 a 1912 o ciclo da borracha viveria seu auge, levando à exportação recorde de 40 mil toneladas do produto em 1910, alçando o Brasil ao posto de líder mundial, aumento da produção que, segundo Celso Furtado, “deveu-se exclusivamente ao influxo de mão-de-obra, pois os métodos de produção em nada se modificaram"31.

O fenômeno acarretaria intensa urbanização de pólos como Manaus, Porto Velho e Rio Branco, em época áurea marcada pelas obras arquitetônicas como o Teatro Amazonas, em Manaus, o Teatro da Paz, o Cinema Olympia, o Palácio do Governo e o Mercado Municipal na capital Paraense ${ }^{32}$. Apesar da ostentação e aparente prosperidade, o modo de obtenção do látex, forçosamente baseado na coleta, deu causa a que, ao contrário do que ocorrera na região centro-sul com a economia cafeeira, não

\footnotetext{
27 “A emigração em larga escala se inicia com a grande seca, de 1877 a 1879, a qual deixou memória em toda a região até os dias de hoje. Três anos seguidos sem chuvas, sem semeaduras, sem colheitas, os rebanhos morrendo, os homens fugindo para não morrer". (in FACÓ, Rui. Cangaceiros e Fanáticos, Gênese e Lutas. Rio de Janeiro-RJ. Editora UFRJ, 2009)

${ }^{28}$ Segundo Ana Miranda, hoje se calcula que morreram cerca de quinhentas mil pessoas em consequência da seca de 1877. "O engenheiro André Rebouças, abolicionista, negro, respeitado por suas ideias progressistas, calculava em mais de dois milhões as pessoas atingidas pela seca, ainda em novembro de 1877". (http://www.opovo.com.br/app/colunas/anamiranda/2013/03/09/noticiasanamiranda,3018832/agrande-seca-de-1877.shtml. Consulta realizada em 17/11/2015)

${ }^{29}$ D'AGOSTINI, S. et alii. Ciclo Econômico da Borracha - Seringueira Hevea Brasiliensis. Arg. (http://www.biologico.sp.gov.br/docs/pag/v9_1/dagostini3.pdf. Consulta realizada em 07/07/2015)

${ }^{30}$ Ibidem.

${ }^{31}$ FURTADO, Celso. Formação Econômica do Brasil. 24 cd. São Paulo, Editora Nacional. Pg. 133. Edição on-line.

${ }^{32}$ D'Agostini, S. et alii. Ciclo Econômico da Borracha - Seringueira Hevea Brasiliensis. Arg. (http://www.biologico.sp.gov.br/docs/pag/v9_1/dagostini3.pdf. Consulta realizada em 07/07/2015)
} 
ocorressem no Norte grandes mudanças sociais, ficando restrito o desenvolvimento aos centros urbanos, onde vivia a camada social ocupada da intermediação do produto. Se de um lado, porém, o modo de produção e de vida da sociedade da borracha mantinhase intacto, a demografia amazônica experimentaria extraordinário aumento ${ }^{33}$.

O incremento populacional, especialmente ocasionado pela migração abrupta, constituiria a raiz do estabelecimento de relações de trabalho compulsório que ainda hoje assolam a região, e que seriam o estopim de toda a mobilização das populações seringalistas nas décadas de 70 e 80 . Se de um lado o fim da escravidão implicara em relativas mudanças nas relações sociais na economia do café, especialmente atraindo a chegada de imigrantes europeus, a Lei Áurea não fora sentida na cultura da borracha, onde a atividade supunha baixa concentração de seringalistas, levando ao isolamento, em que o único contato se dava com os olhos vigilantes de capangas.

Em 1912 é inaugurada a ferrovia Madeira-Mamoré, para o escoamento da produção da borracha, ao custo de 30 milhões de dólares e a vida de seis mil trabalhadores, atribuindo-se-lhe a alcunha de "Ferrovia do Diabo"34. Apesar dos esforços e sacrifícios humanos, seu funcionamento iniciar-se-ia já durante o declínio da produção, impondo sua desativação parcial em 1930, e integral em $1972^{35}$.

A região do Acre somente seria incorporada ao território brasileiro em 1903, durante o governo do presidente Rodrigues Alves, mediante a assinatura do Tratado de Petrópolis, de 17 de novembro daquele ano, por intervenção do Barão do Rio Branco. Na ocasião, a localidade já era ocupada e explorada por seringalistas brasileiros.

No mesmo ano em que a seca se alastrava pelo nordeste, em 1877, tinha lugar o que se considera ainda hoje o maior episódio de biopirataria da história brasileira, quando o botânico inglês Henry Alexander Wickham deixaria o país com 70 mil sementes de seringueiras paraenses, levando-as para a Inglaterra. Dali, mudas seriam transportadas para plantações no Ceilão e Malásia, ocasionando o declínio da produção

\footnotetext{
${ }^{33}$ Segundo dados de CARDOSO et alii, "em 1823, a atual Região norte contava com uma população em torno de 127 mil que, em 1872, passa a ser de quase 340 mil; em 1900, soma quase 700 mil e, 20 anos mais tarde, algo mais de 1.400.000". in: CARDOSO, Fernando Henrique. Müller, Geraldo. Amazônia: expansão do capitalismo [online]. Rio de Janeiro: Centro Edelstein de Pesquisas Sociais, 2008. Pg. 16. Apanhado histórico do povoamento e seus aspectos econômicos e políticos.

${ }^{34}$ D'AGOSTINI, S. et alii. Ciclo Econômico da Borracha - Seringueira Hevea Brasiliensis. Arg. (http://www.biologico.sp.gov.br/docs/pag/v9_1/dagostini3.pdf. Consulta realizada em 07/07/2015)

${ }^{35}$ Ibidem.
} 
brasileira pela queda brusca nos preços no mercado externo, pondo fim ao primeiro ciclo da borracha nacional. Se em 1878 100\% da produção mundial era brasileira, decairia ela progressivamente até $12 \%$ em $1929^{36}$, atingindo em 1932 tão-somente 6 mil toneladas do produto $^{37}$.

A produção brasileira ainda teria um sopro de renovação em direção ao mercado externo, porém já com custos de produção pouco compensatórios, especialmente nos anos que seguiram 1927, quando a busca pelo controle de toda a cadeia de produção dos automóveis pela indústria norte-americana - tornando-se, assim, autônoma em relação à produção britânica na Malásia - impulsionaria a criação no país do chamado "Projeto Ford", conhecido hoje pelos resquícios da "Fordlândia", levantada sobre as margens do Rio Tapajós, que teria declínio completo até o ano de 1945.

O início da segunda guerra mundial representaria uma tentativa de sobrevida para a borracha brasileira, em especial devido ao fechamento dos mercados asiáticos e a demanda do produto para materiais bélicos. Na esteira destes acontecimentos, em 1942 são assinados pelos presidentes Getúlio Vargas e Franklin Delano Roosevelt os Acordos de Washington, levando a verdadeira operação de extração do látex da Amazônia em larga escala, episódio alcunhado Batalha da Borracha, em alusão a que a participação brasileira na guerra ocorreria por meio do esforço conjunto na floresta para o fornecimento da desejada matéria-prima. A operação conduziria 100 mil homens à Amazônia, em grande parte vindos, novamente, do Nordeste ${ }^{38}$. O segundo ciclo duraria até 1960, decaindo a produção aos poucos, dentre outros fatores, pelo desenvolvimento do látex sintético. Com o desaquecimento, outros produtos voltariam a ganhar importância na economia local, destacando-se o extrativismo da castanha, a garimpagem e a pecuária.

\footnotetext{
${ }^{36}$ CARDOSO, Fernando Henrique. Müller, Geraldo. Amazônia: expansão do capitalismo [online]. Rio de Janeiro: Centro Edelstein de Pesquisas Sociais. Apanhado histórico do povoamento e seus aspectos econômicos e políticos. 2008. Pg. 19.

${ }^{37}$ D'AGOSTINI, S. et alii. Ciclo Econômico da Borracha - Seringueira Hevea Brasiliensis. Arg. (http://www.biologico.sp.gov.br/docs/pag/v9_1/dagostini3.pdf. Consulta realizada em 07/07/2015)

${ }^{38}$ Ibidem.
} 
Nesta segunda corrente migratória chegaria a Xapuri, no coração do Acre, Estado que mais recebeu migrantes para a economia gomífera ${ }^{39}$, dentre outros, Francisco Alves Mendes, pai do futuramente mundialmente conhecido Chico Mendes, o qual seguiria, desde tenra idade, o ofício de seringalista.

Chico Mendes aprenderia a ler aos 19 anos através do recém chegado a Xapuri Euclides Távora, participante do levante comunista de 1935 e posteriormente da Revolução de 1985 na Bolívia, que surgiria na Floresta perseguido pelo Estado, ali buscando refugiar-se. De seu alfabetizador aprenderia também os ideais sociais e trabalhistas que levariam sua trajetória rumo ao sindicalismo. ${ }^{40}$

PIMENTA (2007, pg. 65) recorda que "com a falência da economia gomífera, a Amazônia mergulhou numa profunda crise econômica. A partir do golpe militar de 1964, ela se tornou novamente palco de todas as atenções vindo novamente a ser considerada um espaço primordial, cuja valorização econômica e integração política assegurariam um futuro próspero ao país". ${ }^{41}$

Quando sob a alcunha de milagre brasileiro infindáveis rodovias começaram a destoar na imensidão do verde amazônico, represas a cobrir e garimpos a descobrir seu solo, ainda se pensava que o norte do país era um vazio despovoado, que seus habitantes não passariam de mitos e lendas. $\mathrm{O}$ avanço do sistema capitalista, homogeneizador de modos de produção e culturas chegara à Amazônia a largos passos, como estratégia dos governos setentistas de integração do norte do Brasil ao eixo sul-sudeste.

Em meio àquele cenário Chico Mendes contestaria as condições espúrias a que eram submetidos os seringalistas da região ${ }^{42}$, em movimentos que mesclariam

\footnotetext{
${ }^{39}$ CARDOSO, Fernando Henrique. Müller, Geraldo. Amazônia: expansão do capitalismo [online]. Rio de Janeiro: Centro Edelstein de Pesquisas Sociais. Apanhado histórico do povoamento e seus aspectos econômicos e políticos. 2008. Pg. 22.

${ }^{40}$ MORO, Javier. Caminhos de Liberdade: A luta pela defesa da Selva. Ed. Planeta. Sao Paulo, SP. 2011.

${ }^{41}$ PIMENTA. José. Indigenismo e Ambientalismo na Amazônia occidental: a propósito dos Ashaninka do rio Amônia. Revista de Antropologia, São Paulo, USP, 2007, v. 50 n. 2. Disponível on-line em: http://www.revistas.usp.br/ra/article/viewFile/27274/29046. Consulta realizada em 17/11/2015.

42 CARDOSO et alii, assim descreveram o chamado "sistema de aviamento", que caracterizava a economia da borracha: " A atividade econômica extrativo-predatória no interior das matas; a distância entre as seringueiras, o que exigia longas caminhadas; as condições impostas pelo proprietário, não permitindo roçado (geralmente, mandioca); a necessidade de mão de obra para aumentar a produção; o pagamento obrigatório dos trabalhadores aos patrões do custo da viagem do nordeste à Amazônia, dos instrumentos de trabalho, das provisões, enfim, o regime de trabalho e o padrão de vida dos seringueiros baseavam-se no endividamento prévio e posterior, isto é, no endividamento reiterado, o que colocou o
} 
demandas de cunho puramente trabalhista, com pleitos relacionados ao meio ambiente e aspectos culturais das populações. A partir de 1976 seria o líder, juntamente com Wilson de Sousa Pinheiro - posteriormente assassinado -, de movimentos conhecidos como "empates", em que os serigalistas impediriam o avanço do desmatamento opondo-se ao maquinário com o próprio corpo. No ano seguinte, fundaria o Sindicato dos Trabalhadores Rurais de Xapuri, sendo eleito vereador no mesmo ano. Em 1981 assume a direção do Sindicato, até o ano de sua morte.

Em 1985 encabeçaria o $1^{\circ}$ Encontro Nacional dos Seringueiros, ampliando a visibilidade do movimento não só internamente, como também internacionalmente. A partir daí já se tinha a consciência de que não mais se tratava de um movimento de classe, senão em prol do reconhecimento das populações tradicionais enquanto tipo sociológico, à semelhança, porém distinto, das categorias de indígenas e quilombolas, carentes de proteção contra o avanço do sistema-mundo ${ }^{43}$.

Em 1987 idealizaria a histórica Aliança entre os povos da floresta que teria lugar em 1989 em Rio Branco, quatro meses após o assassinato de seu grande articulador, unido populações marcadas pela heterogeneidade, mas que tinham em comum conflitos com grileiros e madeireiros, além da ambição pela criação de Terras próprias e a definição de novos direitos.

Naquele evento, unir-se-iam 187 delegações, dentre extrativistas e indígenas dos Estados do Norte, com diferentes origens, etnias, culturas, em prol de causa que se avultava mais importante, tendo como pontos comuns: a resistência às mudanças iminentes, a proteção de suas terras, o apego à tradicionalidade de modos de produção e de vida.

Dentre os pleitos concretos dos extrativistas, estariam, assim, a introdução no ordenamento brasileiro das chamadas Reservas Extrativistas, espelhadas no modelo das Terras Indígenas.

trabalhador nas mãos do proprietário comerciante.”. CARDOSO, Fernando Henrique. Müller, Geraldo. Amazônia: expansão do capitalismo [online]. Rio de Janeiro: Centro Edelstein de Pesquisas Sociais, 2008. Pg. 22. Apanhado histórico do povoamento e seus aspectos econômicos e políticos. ISBç 978-8599662-73-1

${ }^{43}$ Para usar a expressão de Immanuel Wallerstein. WALLERSTEIN, Immanuel. The modern worldsystem. Capitalist agriculture and the origins of the Europena world-economy in the 16th. Century. New York, Academic Press, 1974. 
O episódio significaria o ápice da aproximação de populações tradicionais e povos indígenas do Brasil, a crista de uma curva que começaria a pender para baixo nos anos seguintes, dando lugar a embates e tensões, especialmente ante a sobreposição de direitos. Apesar disso, o evento seria fundamental para a congregação de populações tradicionais de todo o país e de grupos indígenas, evidenciando, por meio do contraste, que aqueles grupos também se inseriam em tipologias próprias, diferenciados do resto da sociedade brasileira. 


\section{Cap. 2.1.1. O Reconhecimento das Populações Tradicionais pelo Ordenamento Jurídico}

Se de um lado a mobilização que perpassou pelas décadas de 1970 e 1980 abrira os olhos das populações tradicionais para suas características próprias, que lhes conferiam posição especial de vulnerabilidade na sociedade, ainda lhes faltava seu reconhecimento pelo Estado brasileiro.

O encontro promovido pela Aliança dos Povos da Floresta atingiria rápido resultado prático com a edição, já em janeiro de 1990, do Decreto 98.897/90, que, atendendo às reivindicações, trouxe ao ordenamento pátrio a figura das Reservas Extrativistas como "espaços territoriais destinados à exploração autossustentável e conservação dos recursos naturais renováveis, por população extrativista" ${ }^{\text {, }}$, impondo ao Poder Executivo criar "reservas extrativistas em espaços considerados de interesse ecológico e social"45.

$\mathrm{Na}$ esteira daquele Decreto, outros tantos viriam nos anos seguintes a dar concretude ao mandamento, criando na prática reservas extrativistas em todo o território nacional $^{46}$, somando hoje $90^{47}$, entre Unidades federais, estaduais e municipais, relegando à gestão pelas populações tradicionais porção territorial superior a $511.725^{2}$ $\mathrm{km}^{2}$, aproximadamente a extensão territorial da França ${ }^{48}$.

Inobstante a ampliação de direitos próprios à populações tradicionais, carecia ainda a legislação de definição acerca de quem seriam estas, vindo nos anos seguintes o tormentoso desafio de conceituá-las a situar-se no epicentro dos debates sobre o tema.

\footnotetext{
${ }^{44}$ Brasil. Decreto 98.897/1990 de 30 de janeiro de 1990.

${ }^{45}$ Brasil. Decreto 98.897/1990 de 30 de janeiro de 1990.

46 A primeira delas, em realidade, fora criada uma semana antes do Decreto geral, em 23 de Janeiro de 1990, por meio do Decreto 98.863/90.

${ }^{47}$ Segundo dados do observatório de unidades de conservação mantido pela IUCN, consulta realizada em $10 / 09 / 2015$.

${ }^{48}$ A França possui a extensão total de $543.965^{2} \mathrm{Km}^{2}$.
} 
O primeiro esforço veio com a propositura da lei 9.985/00, que, ao incluir as Reservas Extrativistas no rol de Unidades de Conservação trazia em seu texto original definição de população tradicional que ao final restou vetada pela Presidência da República. O conceito e a mensagem de veto presidencial assim diziam:

\begin{abstract}
"XV - população tradicional: grupos humanos culturalmente diferenciados, vivendo há, no mínimo, três gerações em um determinado ecossistema, historicamente reproduzindo seu modo de vida, em estreita dependência do meio natural para sua subsistência e utilizando os recursos naturais de forma sustentável;
\end{abstract}

\title{
Razões do veto
}

"O conteúdo da disposição é tão abrangente que nela, com pouco esforço de imaginação, caberia toda a população do Brasil.

De fato, determinados grupos humanos, apenas por habitarem continuadamente em um mesmo ecossistema, não podem ser definidos como população tradicional, para os fins do Sistema Nacional de Unidades de Conservação da Natureza. O conceito de ecossistema não se presta para delimitar espaços para a concessão de benefícios, assim como o número de gerações não deve ser considerado para definir se a população é tradicional ou não, haja vista não trazer consigo, necessariamente, a noção de tempo de permanência em determinado local, caso contrário, o conceito de populações tradicionais se ampliaria de tal forma que alcançaria, praticamente, toda a população rural de baixa renda, impossibilitando a proteção especial que se pretende dar às populações verdadeiramente tradicionais.

Sugerimos, por essa razão, o veto ao art. 2o, inciso $\mathrm{XV}$, por contrariar o interesse público." ${ }^{49}$

Sobre o veto, assim se pronunciou SANTILLI (2005, pg. 127):

$\mathrm{O}$ veto ao conceito de população tradicional foi defendido não apenas por preservacionistas, que consideravam a definição excessivamente ampla, e, portanto, suscetível de utilização indevida, como também pelo próprio movimento dos seringueiros da Amazônia, que considerava a definição excessivamente restritiva, pela exigência da permanência na área "há três gerações", pois quando se cria uma Reserva Extrativista ou uma Reserva de Desenvolvimento Sustentável, o que se pretende é assegurar os meios de vida e a cultura das populações extrativistas, independentemente do tempo de permanência na área.

Ao criar o Centro Nacional do Desenvolvimento Sustentado das Populações Tradicionais, a Portaria $n^{\circ}$ 22/92, do Ibama, havia estabelecido a seguinte definição: "comunidades que tradicional e culturalmente têm sua subsistência baseada no extrativismo de bens naturais renováveis".

Estabelecida por um instrumento administrativo, não se pode dizer que esta seja propriamente uma "definição legal" de população tradicional, embora delimite o campo de atuação do órgão.

Ao definir as Reservas Extrativistas e de Desenvolvimento Sustentável, a Lei do SNUC indiretamente estabelece a definição de populações tradicionais, "cuja subsistência

\footnotetext{
${ }^{49}$ Brasil. Lei $9985 / 00$ de 18 de julho de 2000.
} 
baseia-se no extrativismo e, complementarmente, na agricultura de subsistência e na criação de animais de pequeno porte" (no caso das Reservas Extrativistas), ou "cuja existência baseia-se em sistemas sustentáveis de exploração dos recursos naturais, desenvolvidos ao longo de gerações e adaptados às condições ecológicas locais e que desempenham um papel fundamental na proteção da natureza e na manutenção da diversidade biológica" (no caso das Reservas de Desenvolvimento Sustentável). ${ }^{50}$

No ano de 2006 a Lei da Mata Atlântica, lei $n^{0} 11.428 / 06$, veio suprir a lacuna legislativa, considerando, ainda que apenas para efeitos daquela norma:

II - população tradicional: população vivendo em estreita relação com o ambiente natural, dependendo de seus recursos naturais para a sua reprodução sociocultural, por meio de atividades de baixo impacto ambiental; $\left(\operatorname{art} .3^{\circ}, \text { II }\right)^{51}$

E finalmente, um ano mais tarde, o Decreto $n^{\circ}$ 6.040/07, que instituiu a Política de Nacional de Desenvolvimento Sustentável dos Povos e Comunidades Tradicionais, assim definiu, de forma geral:

I - Povos e Comunidades Tradicionais: grupos culturalmente diferenciados e que se reconhecem como tais, que possuem formas próprias de organização social, que ocupam e usam territórios e recursos naturais como condição para sua reprodução cultural, social, religiosa, ancestral e econômica, utilizando conhecimentos, inovações e práticas gerados e transmitidos pela tradição; ${ }^{52}$

Além de inúmeras normas de cunho programático, o Decreto preveria o estabelecimento de um "Plano Nacional de Desenvolvimento Sustentável para os Povos e Comunidades Tradicionais" (art. 6 $6^{\circ}$, II), fazendo referência à Comissão Nacional de Desenvolvimento Sustentável das Comunidades Tradicionais", criada em 2004, como órgão competente para coordenar a implantação da Política.

A despeito da definição então assentada, e da expectativa de maior segurança jurídica em torno do conceito, o que se seguiu na prática foi o massivo ataque à legitimidade do autorreconhecimento daquelas comunidades enquanto tradicionais. Dos canastreiros no sul de Minas Gerais, às comunidades ribeirinhas da Terra do Meio, no Estado do Pará, comunidades tradicionais de todo o país experimentariam nos anos vindouros verdadeira via crucis para provar sua condição peculiar, ou, a "medida de sua tradicionalidade", a fim de fazer jus ao tratamento diferenciado prometido pelo Estado para tais populações.

\footnotetext{
${ }^{50}$ SANTILLI, Juliana. Socioambientalismo e Novos Direitos. Proteção juridical à diversidade biológica e cultural. IEB. São Paulo: 2005, pg. 127.

${ }^{51}$ Brasil. Lei 11.428/06, de 22 de dezembro de 2006.

${ }^{52}$ Brasil. Decreto n ${ }^{\circ}$ 6.040/07 de 07 de fevereiro de 2007.
} 
Com a promulgação no país da Convenção n ${ }^{\circ} 169$ da Organização Internacional do Trabalho ${ }^{53}$, trazendo normas protetivas a Povos Indígenas e Tribais em Países Independente, sobreveio forte pressão de estudiosos que defendiam sua aplicação também às populações tradicionais.

O entendimento, embora controverso, obteve, inclusive, o precioso apoio do Ministério Público Federal, assim consignado em seu "Manual de Atuação: Comunidades Tradicionais e as Unidades de Conservação de Proteção Integral. Alternativas para o Asseguramento de Direitos Socioambientais " ${ }^{2}$. A tentativa de ampliação do alcance da norma partiria da definição contida na própria Convenção, segundo a qual era destinada:

a) aos povos tribais em países independentes, cujas condições sociais, culturais e econômicas os distingam de outros setores da coletividade nacional, e que estejam regidos, total ou parcialmente, por seus próprios costumes ou tradições ou por legislação especial;

b) aos povos em países independentes, considerados indígenas pelo fato de descenderem de populações que habitavam o país ou uma região geográfica pertencente ao país na época da conquista ou da colonização ou do estabelecimento das atuais fronteiras estatais e que, seja qual for sua situação jurídica, conservam todas as suas próprias instituições sociais, econômicas, culturais e políticas, ou parte delas. (Art. $1^{\circ}$ da Convenção, conforme redação do Decreto 5051/04) .

Extrai-se da definição critérios objetivos e subjetivos para o enquadramento como indígenas e tradicionais. A própria Organização Internacional do Trabalho, reconhecendo a dificuldade da subsunção, expediu uma série de documentos esclarecedores. O denominado Direitos de Povos Indígenas e Tribais na Prática estruturou capítulo próprio chamado I. Identificação de Povos Indígenas e Tribais, onde assim informou:

Os elementos traçados no Artigo 1 constituem os critérios objetivos de abrangência da Convenção $\mathrm{n}^{\circ} 169$. Pode-se objetivamente aferir se um específico povo indígena ou tribal preenche os requisitos do Artigo 1 e se um dado indivíduo é reconhecido e aceito como pertencente àquele grupo. $\mathrm{O}$ dispositivo reconhece a autoidentificação de povos indígenas e tribais como um critério. Este é o critério subjetivo da Convenção, a qual agrega fundamental importância à autopercepção do indivíduo como tal. A Convenção foi o primeiro instrumento internacional a reconhecer a importância da autoidentificação.

\footnotetext{
${ }^{53}$ A Convenção foi promulgada no Brasil pelo Decreto no 5051/04 de 19 de abril de 2004.

54 Disponível em: http://6ccr.pgr.mpf.mp.br/documentos-e-publicacoes/manual-de-atuacao/manual-deatuacao-territorios-de-povos-e-comunidades-tradicionais-e-as-unidades-de-conservacao-de-protecaointegral (Consulta realizada em 17/11/2015)
} 
A cobertura da Convenção é baseada na combinação do critério objetivo com o subjetivo. Assim, a autoidentificação complementa o critério objetivo, e vice-versa. A convenção possui uma abordagem inclusiva e é igualmente aplicável tanto a povos indígenas como tribais. A Convenção foca, assim, na situação presente de povos indígenas e tribais, embora o histórico de continuidade e conexão territorial sejam importantes elementos na identificação dos povos indígenas. $\mathrm{O}$ critério elaborado no Aritgo 1, b, da Convenção 169 tem sido aplicado amplamente para o propósito de identificação de povos indígenas em políticas nacionais e internacionais, bem como em processos legais, para além do grupo de Estados que ratificarão a convenção. Ela é utilizada como uma definição de trabalho internacional para o propósito de identificar povos indígenas, inclusive no âmbito da Declaração de Direitos Indígenas das Nações Unidas, sendo, também base para que várias de suas agências especializadas estabelecessem definições operacionais, dentre elas o Banco Mundial e o Programa de Desenvolvimento das Nações Unidas. ${ }^{55}$

A despeito dos esforços, não houve até o momento reconhecimento formal pelo Poder Executivo federal da aplicação daquela norma às populações tradicionais, restando, sem embargo do amplo conjunto normativo já sedimentado, a polêmica em se delimitar as fronteiras da expressão "população tradicional", permanecendo a dificuldade ínsita em identificá-las na prática.

\footnotetext{
${ }^{55}$ Disponível 


\section{Cap. 2.2. Os Indígenas na Perspectiva do Estado Brasileiro}

Se de um lado a definição das populações tradicionais é ainda objeto de acirradas disputas, de outra parte também a definição do indígena não fica alheia a controvérsias, o que vem desaguando na dificuldade experimentada por estes povos na consecução da demarcação de suas terras.

Segundo MARETTI (2004, pg. 85),

Como é sabido, em inglês, o termo indigenous tem significado de local, original, proveniente do lugar ou nativo. Portanto, não é equivalente ao termo indígena. Outros preferem considerar indígenas como grupos sociais culturalmente diferentes. Há também quem considere que as considerações não se aplicam somente aos indígenas, mas a outros grupos sociais que chamam 'tradicionais'. Ou, ainda, inclui-los dentre as comunidades locais.

Em português, o termo 'indígena' normalmente é usado mais no sentido de povos, grupos sociais ou étnicos (ou características a eles relacionadas) que se encontravam na América antes da chegada dos europeus - e é aproximadamente essa a forma como o termo é aqui utilizado. Isso aplicado ao resto do mundo refere-se àqueles grupos sociais que são anteriores a novos grupos sociais que tenham colonizado o mesmo lugar, área, região, país ou continente - ainda que não necessariamente originais stricto sensu à área considerada. Ou para marcar a diferença quando tais povos foram estudados por europeus ou seus descendentes. Em função dessa relação, 'indígena' tem sido, mesmo que nem sempre, também entendido como cultural ou etnicamente diferente ou diferenciado, pré-capitalista, não-desenvolvido, minoritário, pseudo-minoritário, social ou economicamente marginal, entre outros conceitos - ainda que não necessariamente se defendam todas essas compreensões.

\section{(..)}

Para o Grupo Internacional de Trabalho sobre Assuntos Indígenas ("International Work Group on Indigenous Affairs - IWGIA") os povos indígenas são os descendentes dos povos que habitavam um território antes da colonização ou formação do estado atual, que estejam socialmente em desvantagem. O termo indígena é definido por características que se relacionam com a identidade de um povo específico numa área específica e que os distingue culturalmente de outro povo ou povos. De acordo com o Banco Mundial, os termos 'povos indígenas', 'minorias étnicas', 'grupos tribais' ou 'tribos de castas ou classes mais baixas' descrevem grupos sociais com identidades sociais e culturais distintas da sociedade dominante, o que lhes faz vulneráveis a prejuízos no processo de desenvolvimento. Normalmente estão entre os segmentos mais pobres de uma população e desenvolvem atividades que vão desde agricultura itinerante em florestas ou em suas bordas até empregos ou atividades de mercado de pequena escala. Por causa dos variados e mutáveis contextos nos quais os povos indígenas são encontrados, nenhuma definição simples pode englobar sua diversidade. No entanto, segundo essa instituição, o termo 'povos indígenas' pode ser aplicado àqueles povos que, em áreas específicas, mostram, em vários graus, as características seguintes: ligação intensa com os territórios ancestrais e com os recursos naturais dessas áreas; autoidentificação e identificação pelos outros como grupos culturalmente distintos; 
linguagem própria, a qual não raro não é a língua nacional; suas próprias e tradicionais instituições sociais e políticas; sistemas de produção predominantemente voltados à subsistência. ${ }^{56}$

No ordenamento legal brasileiro, dispõe o Estatuto do Índio:

Art. $3^{\circ}$ Para os efeitos de lei, ficam estabelecidas as definições a seguir discriminadas:

I - Índio ou Silvícola - É todo indivíduo de origem e ascendência pré-colombiana que se identifica e é identificado como pertencente a um grupo étnico cujas características culturais o distinguem da sociedade nacional; ${ }^{57}$

A equivocidade do termo coincide com a multiplicidade de tratamento dado a tais populações nos diversos países. Por exemplo, estabeleceram os Estados Unidos o critério que passou a ser conhecido como "cota de sague", em que os indivídios necessitam comprovar a presença de pelo menos 1/16 de sangue indígena (ao menos um bisavô na linha ancestral) para assim serem reconhecidos pelo Estado; enquanto países como o Brasil mantiveram o foco na organização social e na autoidentificação pelo grupo, desvinculando-se, assim, do aspecto biológico, em direção ao sociológico.

Sedimentando esta diretriz, ao firmar o Brasil a já citada Convenção no 169 da Organização Internacional do Trabalho, promulgada pelo Decreto 5.051, de 19 de Abril de 2004, assim assentou, tornando-se o principal instrumento legal sobre o tema:

1. A presente convenção aplica-se:

a) aos povos tribais em países independentes, cujas condições sociais, culturais e econômicas os distingam de outros setores da coletividade nacional, e que estejam regidos, total ou parcialmente, por seus próprios costumes ou tradições ou por legislação especial;

b) aos povos em países independentes, considerados indígenas pelo fato de descenderem de populações que habitavam o país ou uma região geográfica pertencente ao país na época da conquista ou da colonização ou do estabelecimento das atuais fronteiras estatais e que, seja qual for sua situação jurídica, conservam todas as suas próprias instituições sociais, econômicas, culturais e políticas ou parte delas.

2. A consciência de sua identidade indígena ou tribal deverá ser considerada como critério fundamental para determinar os grupos aos quais se aplicam as disposições da presente Convenção ${ }^{58}$.

Paralelamente à definição, expressaria a Convenção, no mesmo artigo, item 2, que "a consciência de sua identidade indígena ou tribal deverá ser considerada como

\footnotetext{
${ }^{56}$ MARETTI, Cláudio. Conservação e valores. Relações entre áreas protegidas e indígenas: possíveis conflitos e soluções. In: In: RICARDO, Fany (org.). Terras Indígenas \& Unidades de Conservação da natureza: o desafio das sobreposições. São Paulo: Instituto Socioambiental-ISA. 2004.

${ }^{57}$ Brasil. Lei 6001/73, de 19 de dezembro de 1973.

${ }^{58}$ Brasil. Decreto no 5051/04 de 19 de abril de 2004.
} 
critério fundamental para determinar os grupos aos que se aplicam as disposições da presente Convenção ",59.

Denotam-se, assim, três eixos fundamentais para a delimitação dos grupos destinatários da norma: condições sociais, culturais e econômicas diferenciados do restante da sociedade; organização social com base em modos tradicionais; a autoidentificação, a partir da consciência de sua identidade própria. Conjugando-os, tem-se que o autorreconhecimento legitima-se na presença de típica organização e adscrição, noções assim construídas pela antropologia:

"Ele [o grupo] existe como grupo enquanto preserva a sua própria organização em meio a outras organizações sociais entre outros grupos organizacionais, frente a outros tipos de sociedade: equivalentes, diferentes ou desiguais. Ele existe como étnico enquanto preserva a sua própria identidade. Enquanto é capaz de atribuir a si próprio e fazer serem atribuídas pelos outros adscrições enunciadoras de diferenças étnicas: valores de uma identidade étnica" ${ }^{\circ 0}$

Nesta esteira é que,

De acordo com o Banco Mundial, os termos 'povos indígenas', 'minorias étnicas', 'grupos tribais' ou 'tribos de castas ou classes mais baixas' descrevem grupos sociais com identidades sociais e culturais distintas da sociedade dominante, o que lhes faz vulneráveis a prejuízos no processo de desenvolvimento. Normalmente estão entre os segmentos mais pobres de uma população e desenvolvem atividades que vão desde agricultura itinerante em florestas ou em suas bordas até empregos ou atividades de mercado de pequena escala. Por causa dos variados e mutáveis contextos nos quais os povos indígenas são encontrados, nenhuma definição simples pode englobar sua diversidade. No entanto, segundo essa instituição, o termo 'povos indígenas' pode ser aplicado àqueles povos que, em áreas específicas, mostram, em vários graus, as características seguintes: ligação intensa com os territórios ancestrais e com os recursos naturais dessas áreas; autoidentificação e identificação pelos outros como grupos culturalmente distintos; linguagem própria, a qual não raro não é a língua nacional; suas próprias e tradicionais instituições sociais e políticas; sistemas de produção predominantemente voltados à subsistência ${ }^{61}$.

Não obstante, até que se atingisse a relativa clareza legislativa atual, os limites das fronteiras entre índios e não-índios, e o tratamento que se lhes foi despendido sofreu evolução no âmbito da antropologia brasileira e do ordenamento jurídico.

A regulamentação dos direitos indígenas tem como marco inicial o Alvará Régio, de $1^{\circ}$ de abril de 1680 , por meio do qual a coroa portuguesa reconhecia a "posse

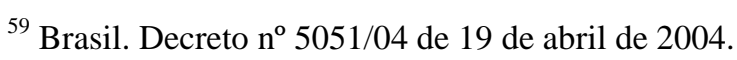

${ }^{60}$ BRANDÃO, CR. Identidade e Etnia. S. Paulo, Ed. Brasiliense, 1986.

${ }^{61}$ MARETTI, Cláudio C. Conservação e valores - Relações entre áreas protegidas e indígenas: possíveis conflitos e soluções. In: RICARDO, Fany (org.). Terras Indígenas \& Unidades de Conservação da natureza: o desafio das sobreposições. São Paulo: Instituto Socioambiental. 2004.
} 
dos índios sobre suas terra, por serem eles os seus primeiros ocupantes"62. O texto, contudo, teve pouca observância, inclusive pelo Império, como se vê da Carta Régia de $02 / 12 / 1808$, que declarava como devolutas as terras conquistadas dos índios. ${ }^{63}$

Com o início da República, inicia-se também o processo de desvinculação da propriedade das terras do poder central para os Estados, vindo estes a arrecadar as terras consideradas devolutas, o que avançava sobre as terras de indígenas.

A primeira Constituição republicana, de 1891, não fazia menção aos índios, já as Constituições de 1934 em diante passam a fazer referência à sua posse sobre as áreas ocupadas, embora as terras indígenas fossem demarcadas neste período em pequenas extensões, muito mais no intuito de passar segurança para as terras ao redor, excluídas da demarcação.

Em 1961 é criado o Parque Nacional do Xingu - posteriormente renomeado Parque Indígena do Xingu -, consistindo em uma guinada na atuação do Estado até aquele momento, que sempre vira os índios como objeto de futura integração ao restante da sociedade. A criação do Parque, ao contrário, permitiria a manutenção de seus modos de vida, embora toda a legislação ainda estivesse atada ao antigo modelo.

Com o governo militar institui-se na emenda constitucional de 1969 o patrimônio da União sobre as terras indígenas, o que evitaria a titulação das mesmas a particulares, conforme acima narrado. Complementarmente, instituía a emenda instituto que se manteria até os dias de hoje, conhecido como o "direito originário" dos índios sobre suas terras, impondo que todos os atos constituídos sobre elas fossem nulos na origem, sem o pagamento de qualquer indenização aos pretendentes. Isto impediria, inclusive, que as terras tituladas indevidamente aos particulares fossem objeto de indenização no momento da incorporação ao patrimônio da União.

Em 1967, em meio a diversas denúncias de irregularidades no então órgão indigenista, o SPI - Serviço de Proteção aos Índios, cria-se a Fundação Nacional do Índio-Funai, com competência para exercer os "poderes de representação ou assistência

\footnotetext{
62 ARAÚJO, Ana Valéria. Terras Indígenas no Brasil: retrospectiva, avanços e desafios do processo de reconhecimento. In RICARDO, Fany (org.). Terras Indígenas \& Unidades de Conservação da natureza: o desafio das sobreposições. São Paulo: Instituto Socioambiental. 2004. pg. 26

${ }^{63}$ Ibidem, pg. 26.
} 
jurídica inerentes ao regime tutelar do índios"64 e garantir a posse dos mesmos sobre suas terras, entre outras atribuições ${ }^{65}$.

Com críticas à sucessão institucional, avaliava ARAÚJO (2004,pg. 29) que,

"Na prática, a Funai se ergueu sobre os escombros do SPI, aproveitando a sua estrutura de pessoal, recursos, etc., E o novo, quando aparecia vinha na forma de funcionários sem nenhuma experiência de trabalho com os índios, provenientes de outros órgãos que, funcionando em Brasília, estavam sendo transferidos para outras partes do país”. ${ }^{66}$

Em 1973 é editada, na sequência das mudanças implementadas pelo governo militar, o Estatuto do Índio, Lei 6.001/73, ainda em vigor, embora grande parte de seus dispositivos já se encontrem anacrônicos em relação à atual Constituição.

Apesar do esforço de inovação legislativa, o novel Estatuto ainda estaria preso a antigos paradigmas, afirmando, por exemplo, já em seu primeiro artigo: "Esta Lei regula a situação jurídica dos índios ou silvícolas e das comunidades indígenas, com o propósito de preservar a sua cultura e integrá-los, progressiva e harmoniosamente, à comunhão nacional "67. A menção expressa à integração levaria críticos a chamar os destinatários da lei de "sujeitos em trânsito".

Seguindo este histórico, e com alicerce nas fronteiras conceituais firmadas é que Terras Indígenas vêm sendo demarcadas em todo o país, já somando hoje 545 - dentre delimitadas, declaradas, homologadas e regularizadas ${ }^{68}$-, além de 125 outras em estudo $^{69}$.

\footnotetext{
${ }^{64}$ Brasil. Lei 5371, de 5 de dezembro de 1967. Art. $1^{\text {o }}$, parágrafo único.

${ }^{65}$ Brasil. Lei 5371, de 5 de dezembro de 1967. Art. $1^{\circ}$, b.

${ }^{66}$ ARAÚJO, Ana Valéria. Terras Indígenas no Brasil: retrospectiva, avanços e desafios do processo de reconhecimento. In RICARDO, Fany (org.). Terras Indígenas \& Unidades de Conservação da natureza: o desafio das sobreposições. São Paulo: Instituto Socioambiental. 2004. pg. 29

${ }^{67}$ Brasil. Lei 6001/73, de 19 de dezembro de 1973.

${ }^{68}$ Cada uma das expressões significa fase distinta no longo processo de criação de Terras Indígenas.

${ }^{69}$ Consulta realizada em 20/09/2015, no sítio da Funai: http://www.funai.gov.br/index.php/indios-nobrasil/terras-indigenas
} 


\section{Cap. 2.3. Reservas Extrativistas $\mathrm{x}$ Terras Indígenas}

"Ele considerou a gente como extrativista e não tinha o direito nem de falar, porque a Lei deles era maior do que a nossa, a Funai tinha mais poder do que a gente",70.

Conforme acima se problematizou, do histórico do surgimento de Terras Indígenas e Reservas Extrativistas decorre um conjunto significativo de diferenças entre seus atuais regimes jurídicos. Neste capítulo busca-se objetivamente elencar suas características e, sobretudo, diferenças, acentuando-se as diferenças experimentadas por cada um dos grupos em face da mera categorização.

Segundo aludido, atendendo as reivindicações de populações tradicionais foilhes destinada no ano de 1990 modalidade de terra que prestigiaria não só o aspecto social, como também o ambiental, então definidas pelo Decreto $\mathrm{n}^{\circ}$ 98.897/90 como “espaços territoriais destinados à exploração autossustentável e conservação dos recursos naturais renováveis, por população extrativista". ${ }^{71}$

ARRUTI (2013, pg. 1), de forma crítica, assim fornecia sua interpretação sobre o fato:

Foi na esteira do multiculturalismo em ascensão no último quarto de século passado, assim como sob o entusiasmo com o processo de redemocratização, que o Estado Brasileiro se abriu ao reconhecimento da pluralidade de sua formação social e cultural para além da triste fábula das três raças tristes. Esse contexto foi sobreposto por outro, moldado pela emergência de uma forte preocupação global com o meio ambiente, que teria no ano de 1992 seu marco fundamental. A sobreposição desses dois contextos criou o ambiente propício para que movimentos e demandas sociais até então invisibilizados, quase sempre marcados por uma territorialidade particular, por conhecimentos e formas de manejo ambiental tradicionais, viessem à luz e pudessem se fortalecer politicamente ${ }^{72} .73$

\footnotetext{
70 Trecho de missiva do Presidente da Associação representativa da população tradicional da comunidade Itaboca. SILVA, Katiane. Conscientização, tradição e desenvolvimento. Intratextos, Rio de Janeiro, 6(1): 2014, pg. 14.

${ }^{71}$ Brasil. Decreto n 98.897 de 30 de janeiro de 1990.

72 ARRUTI, José Maurício. Sobre Políticas de Reconhecimento e Sobreposições Territoriais. Revista do Centro de Estudos Rurais - UNICAMP 2013. São Paulo. V. 7, n2, pg 1.

${ }^{73}$ Cumpre registrar que a ideia de uma categoria de Unidade de Conservação voltada para o uso sustentável dos recursos naturais não é nova, tendo constado, inclusive, da tipologia sugerida pela UICN
} 
Uma década mais tarde, com a edição da Lei 9.985/00 que sistematizou o conjunto de Unidades de Conservação, as Resex seriam definitivamente elencadas dentre as chamadas Unidades de Conservação, então definidas como o "espaço territorial e seus recursos ambientais, incluindo as águas jurisdicionais, com características naturais relevantes, legalmente instituído pelo Poder Público, com objetivos de conservação e limites definidos, sob regime especial de administração, ao qual se aplicam garantias adequadas de proteção". ${ }^{74}$

Da circunstância de terem sido vontadas à proteção ambiental, algumas limitações restariam nítidas às populações tradicionais, quando comparado o modelo com o das Terras Indígenas. Por exemplo, o art. $2^{\circ}$ do Decreto 98.897/90 disporia que as reservas seriam criadas em espaços de interesse ecológico e social, assim consideradas suas "características naturais ou exemplares da biota que possibilitem a sua exploração autossustentável, sem prejuízo da conservação ambiental"75.

Resgata-se que a esta época a Constituição Federal de 1988 já sacramentara os direitos originários dos índios "sobre as terras que tradicionalmente ocupam, competindo à União demarcá-las, proteger e fazer respeitar todos os seus bens" ${ }^{\text {,76 }}$. As terras tradicionalmente ocupadas seriam definidas pelo próprio constituinte como aquelas "por eles habitadas em caráter permanente, as utilizadas para suas atividades produtivas, as imprescindíveis à preservação dos recursos ambientais necessários a seu bem-estar e as necessárias a sua reprodução física e cultural, segundo seus usos, costumes e tradições". ${ }^{77}$

Desta forma, se de um lado o Poder Público tão-somente "reconheceria" as terras indígenas, tendo estes o direito originário sobre as mesmas, o que afastaria a

\footnotetext{
- International Union of Conservation of Nature, com as seguintes características: "Categoria VI. Áreas protegidas que conservam ecossistemas e habitats em associação com valores culturais e tradicionais voltados para o manejo dos sistemas. Geralmente amplas, com a maior parte de suas áreas em condições naturais, onde uma porção é reservada para o manejo sustentável dos recursos, com níveis baixos de industrialização ou sem industrilização, de modo compativel com a Natureza. In UICN. "Guidelines for applyin protected area manangement categories". (disponível em: cmsdata.iucn.org/downloads/guidelines_for_applying_protected_area_management_categories.pdf. Consulta realizada em 19/11/2015)

${ }^{74}$ Brasil. Lei 9985 , de 18 de julho de 2000 , art. $1^{\circ}$, I.

${ }^{75}$ Brasil. Decreto $n^{\circ} 98.897$ de 30 de janeiro de 1990, art. $2^{\circ}$.

${ }^{76}$ Brasil. Constituição Federal de 05 de outubro de 1988, art. 231.

${ }^{77}$ Brasil. Constituição Federal de 05 de outubro de 1988, art. 231, $§ 1^{\circ}$.
} 
discricionariedade do Estado em conceder-lhe ou não a terra, apenas devendo perpassar pelo procedimento formal que levaria à demarcação, por outro lado as Reservas Extrativistas dependeriam do interesse político em reservar a área demandada para a conservação ambiental por meio do uso sustentável pelas populações, não havendo obrigatoriedade de sua criação. É o que esclarecia CHACPE (2014 pg. 65):

Os territórios indígenas (e os territórios de quilombolas) distinguem-se, portanto, das Unidades de Conservação ambiental, criadas por atos do Poder Público de natureza constitutiva. A terra é indígena (ou quilombola) desde sempre, e não em função do ato oficial de demarcação: já o Parque, a Reserva Biológica etc. só passam a existir juridicamente enquanto tal após a edição do ato oficial de criação. É o Poder Público que vai definir a categoria, os limites e os locais onde serão criadas as UCs, a fim de cumprir a sua obrigação constitucional de criar espaços territoriais especialmente protegidos, um dos instrumentos da Política Nacional de Meio Ambiente. Trata-se, portanto, do exercício de um poder administrativo com grande margem de discricionariedade, o que não ocorre com os atos de reconhecimento de Terras Indígenas e de quilombolas, claramente vinculados ${ }^{78}$.

Em síntese, decorre que se as terras indígenas uma vez demarcadas não estão sujeitas a desconstituição; são compostas por imóveis de domínio público; podem se sobrepor a outras Unidades de Conservação da Natureza sem que isto implique na saída daquela população ${ }^{79}$; estão sob gestão dos próprios indígenas; de sua parte as Resex nasceriam sem constituir direito inexorável da população tradicionalmente, sendo, senão, fruto da discricionariedade política para sua criação; estariam, de maneira oposta às primeiras sujeitas à gestão e manejo por órgão público - antes o IBAMA, e desde 2007 o Instituto Chico Mendes de Conservação da Biodiversidade-ICMBio -; no confronto decorrente da sobreposição de suas terras com outra Unidade de Conservação onde a ocupação seja vedada, far-se-ia necessário o reassentamento da população tradicional; entre outras distinções.

Mais incisivas, entretanto, seriam as restrições de cunho ambiental que incidiriam sobre as Reservas Extrativistas, ante o fato de se enquadrarem como Unidades de Conservação, sendo-lhes vedado, por exemplo, mesmo a criação de animais de médio e grande porte. Estudando os índios Munduruku, no Pará, obteve

\footnotetext{
78 CHACPE, Juliana Fernandes. Territórios Quilombolas e Unidades de Conservação de Proteção Integral: desafios da conciliação na Administração Federal. Dissertação de Mestrado. UNB 2014. Pg. 65

79 Conforme decidido pelo Supremo Tribunal Federal no paradigmático julgamento do caso "Raposa Serra do Sol". (http://stf.jusbrasil.com.br/jurisprudencia/3817597/peticao-pet-3388citar os embargos (consulta realizada em 16/11/2012). Esclarece-se que após o julgamento do mérito da ação foi interposto recurso de embargos de declaração, que esclareceu e eliminou contradições e obscuridades em pontos específicos do julgado.
} 
certa feita VAZ FILHO (2004, pg. 572) a seguinte declaração, que aponta para tal diferença no regime das terras:

Ao ser indagado sobre o que mudou na vida da comunidade depois que se assumiram como indígenas, o líder de Takuara respondeu que agora podia caçar queixada que estragava sua roça sem medo da repressão do Ibama. Tal afirmação ilustra como o 'libertar-se' do controle do Ibama e o "assumir-se" como indígena estão muito intimamente ligados, ainda que aquele não seja a única motivação deste ${ }^{80}$.

Prosseguindo, afigura-se pelo teor do Decreto 98.897/90 que, visando proteger as populações das pressões do capital, determinou-se que as áreas permaneceriam sob domínio público, com “direito real de uso concedido a título gratuito" às mesmas ${ }^{81}$. Desta forma, a exploração autossustentável e a conservação dos recursos naturais restou "regulamentada por contrato de concessão real de uso" que incluiria um plano de utilização aprovado pelo ICMBio com cláusula de rescisão nas hipóteses de danos ao meio ambiente ou a transferência da concessão. Tais dispositivos representariam, de forma cabal, a ingerência do Poder Público sobre as atividades dos tradicionais, o que não ocorreria em mesma dimensão nas análogas Terras Indígenas. ${ }^{82}$

No mesmo sentido, dispõe o art. $5^{\circ}$ da norma que "Caberá ao Ibama supervisionar as áreas extrativistas e acompanhar o cumprimento das condições estipuladas no contrato de que trata o artigo anterior" ${ }^{\text {" } 83} 84$.

O resultado contrariaria a opinião de especialistas, para quem falar em etnodesenvolvimento seria falar em autonomia política das comunidades étnicas ${ }^{85}$. É a opinião que compartilham ALMEIDA \& REZENDE (2013, pg 192) assim destacando a diferença:

E, com efeito: nas Terras Indígenas, além de políticas de qualidade de vida que respeitam suas peculiaridades, há um grau mínimo de autonomia e de reconhecimento do poder local, ao passo que nas Resex amiúde quem manda são políticos locais e

\footnotetext{
${ }^{80}$ VAZ FILHO. As Comunidades Munduruku na Flona do Tapajós. RICARDO, Fany (org.). Terras Indígenas \& Unidades de Conservação da natureza: o desafio das sobreposições. São Paulo: Instituto Socioambiental. 2004. Pg. 572.

${ }^{81}$ Brasil. Decreto $n^{\circ} 98.897$ de 30 de janeiro de 1990, art. $4^{\circ} . \S^{\circ}$.

${ }^{82}$ Brasil. Decreto ${ }^{\circ} 98.897$ de 30 de janeiro de 1990, art. $4^{\circ}$.

${ }^{83}$ Brasil. Decreto no 98.897 de 30 de janeiro de 1990, art. $5^{\circ}$.

${ }^{84}$ Neste munus foi o IBAMA suscedido pelo ICMBio em 2007, nos termos da Lei 11.516/07

85 ATHIAS, Renato. A noção de identidade étnica na antropologia brasileira. De Roquette Pinto a Roberto Cardoso de Oliveira. Editora Universitária UFPE. Recife, PE. 2007. Pg,20.
} 
prefeitos, e chefes nomeados pelo ICMBio desrespeitam modos de vida tradicionais tratando os moradores como intrusos em seus territórios tradicionais ${ }^{86}$.

Os autores seriam igualmente contundentes ao apontar as falhas no modelo relacional entre Estado e populações tradicionais:

Nossa tese é simples: a razão principal para isso é a inoperância do ICMBio como agência administradora de territórios de uso tradicionais. De fato, o ICMBio, apesar do seu nome que evoca a figura de Chico Mendes, o defensor histórico de territórios tradicionais geridos por seringueiros e outras comunidades tradicionais, tornou-se um órgão de administração de unidades de conservação ambiental distanciado de povos e comunidades tradicionais.

Cumpre notar, com apoio em ATHIAS (2007, pg 25), que organizações internacionais temáticas vêm sustentando um rol de direitos mínimos a serem garantidos a populações indígenas. Atentando-nos para a lista, afigura-se que grande parte daqueles direitos encontram-se hoje, em maior ou menor medida, reservados aos indígenas pela legislação pátria - ainda que sua aplicação reste, muitas vezes, obstada na prática por diversos fatores -, o que não se tem garantido às populações tradicionais, denotando a diferença de estágio no tratamento entre os grupos. Seriam eles:

1. A clareza nos direitos de propriedade da terra. Aqui se verifica tudo que diz respeito aos territórios indígenas: as questões sobre a utilização do solo e do subsolo e a plena utilização das terras, tendo a Constituição de 1988 já avançado nessas questões, porém sem uma legislação complementar;

2. O reconhecimento e a garantia da voz política dos povos indígenas, não só como cidadãos individuais, mas sobretudo como povo, como grupo, como culturas distintas. Isso significa aceitar as relações interculturais. Esse reconhecimento proporciona aos grupos étnicos agentes ativos de seu próprio desenvolvimento;

3. $\mathrm{O}$ respeito à identidade cultural indígena, tendo em conta que qualquer modelo de desenvolvimento econômico deveria fortalecer as diversas identidades;

4. O reconhecimento formal das organizações existentes entre os povos indígenas, assegurando as suas formas próprias de gestão e representação política em projetos apoiados pelos governos;

5. Apoios a iniciativas indígenas que visem à ampliação dos recursos naturais existentes nas áreas indígenas, buscando fortalecer seus modelos de gestão dos recursos naturais em suas terras;

6. Apoios concretos à manutenção da segurança alimentar nos territórios indígenas, respeitando as práticas tradicionais de exploração dos recursos naturais;

7. A responsabilidade social do Estado em apoiar serviços de saúde dignos e de qualidade nas áreas indígenas; uma educação intercultural bilíngüe e atividades que possam promover a geração de renda respeitando as tradições culturais dos povos indígenas. Esses pontos acima mencionados não estão isolados.

${ }^{86}$ ALMEIDA, Mauro W. Barbosa e REZENDE, Roberto Sanches. Uma Nota sobre Comunidades Tradicionais e Unidades de Conservação. Revista do Centro de Estudos Rurais - UNICAMP 2013. São Paulo. V. 7, n2. Pg. 192. 
Para colocar em andamento uma política de etnodesenvolvimento clara, com respeito às identidades étnicas, deveriam ser interconectados e deverão ser visto como formas internas de discussão sobre questões de desenvolvimento entre os povos indígenas". ${ }^{87}$

Também os Conselhos Deliberativos, colegiados responsáveis pela administração das áreas seriam alvo de críticas contundentes nos anos seguintes à sua implementação. Os Conselhos haviam sido inseridos na proposta das Reservas em resposta aos pleitos das populações tradicionais de autonomia sobre suas terras, mas, sobretudo, como consequência da "onda participacionista" que se erguera nos anos 1980 em todo o mundo. Naquele contexto, Bancos e entidades de fomento internacionais, financiadores de projetos estruturais no Brasil, passaram a demandar a ampliação da participação como requisito para a concessão de empréstimos, fazendo, ao final, prosperar a proposta da gestão participativa nos Conselhos das Reservas ${ }^{88}$.

$\mathrm{Na}$ prática, entretanto, reconhece-se que a gestão das áreas pelas populações habitantes restou minimizada pela amplitude da pluralidade da composição dos Conselhos, além de problemas em sua estruturação. O fato é apontado por ALMEIDA \& REZENDE (2013 pg. 190), que assim descrevem:

"O Conselho é dividido entre representantes locais e representantes externos, e pode incluir prefeitos, delegados de polícia, fazendeiros, comerciantes e representantes de ONGs. Além do mais, o Conselho é presidido pelo próprio chefe de Unidade, a quem cabe o voto de desempate sobre questões polêmicas. Tais Conselhos não conseguem se reunir regularmente e são inteiramente inócuos para gerir de fato uma Reserva Extrativista ou uma Reserva de Desenvolvimento Sustentável. Além do mais, eliminam qualquer autoridade de Associações ou outros coletivos locais. Dessa maneira, os

87 ATHIAS, Renato. A noção de identidade étnica na antropologia brasileira. De Roquette Pinto a Roberto Cardoso de Oliveira. Editora Universitária UFPE. Recife, PE. 2007. Pg,27.

${ }^{88}$ Segundo SANTOS (2007), "na década de 80, a visão sobre participação teve sensível mudança passando a ganhar relevância na estratégia para a proteção. Acreditam, no entanto que foi na década de 90 que a participação passou a ser vista com mais profundidade como meio de envolver a população no manejo de áreas protegidas". Neste contexto, aponta o papel do Banco Mundial e do BID na exigência de ampliação da participação como requisito para financiamento dos empreendimentos de infraestrutura brasileiros daquele período. Em documento formal divulgado pelo primeiro, assim se fez constar:

"É de interesse do Banco possibilitar e encorajar os tomadores de empréstimo a buscar enfoques mais participativos de forma a facilitar a obtenção de melhores resultados nas políticas implementadas. O banco não pode se colocar como governo. Nós não governamos os países. Os projetos não são o Banco Mundial e nem a sociedade civil (...). O que nós podemos fazer é ajudar a liderar uma mudança no ambiente. Nós não podemos comandar a mudança. Más nós podemos ajudar a liderá-la. Nós podemos definir a estrutura para atraí-los. (The World Bank Participation Sourcebook. 1996. Disponível em http://documents.worldbank.org/curated/en/1996/02/696745/worldbank-participation-sourcebook) SANTOS, Edson Vanda Pereira dos Santos. "Diálogos, Práticas e Espaços Participativos: A Participação da Comunidade da Reserva Extrativista Cazumbá-Iracema/Acre no Programa Biodiversidade Brasil-Itália. Dissertação de Mestrado . UFRRJ. 2007 
moradores se veem de fato à mercê do poder de "chefes" nomeados pelo ICMBio que são via de regra biólogos inexperientes, aprovados em concursos públicos que não exigem conhecimentos ou formação especial nas dimensões sociais, culturais e institucionais de Unidades de Conservação habitadas por povos e comunidades tradicionais. À luz dessa situação devem ser lidos os relatos de protestos de comunidades locais contra o arbítrio de gestores de Unidades de Conservação.

\section{$(\ldots)$}

Com esse infeliz dispositivo, as Reservas Extrativistas passam na prática a ser regidas pelo chefe de Unidade, que é escolhido pelo ICMBio sem consulta aos residentes. O "chefe" preside o Conselho Deliberativo, que convoca quando entende. Já o Conselho Deliberativo reúne "representantes de órgãos públicos, de organizações da sociedade civil e das populações tradicionais residentes na área”. Na prática, isso significa um conjunto heteróclito de conselheiros formado por pessoas sem representatividade entre as comunidades e escolhidos por intermédio do ICMBio $^{89}$.

Conforme acima indicado, intenta-se hoje, a fim de minimizar tais diferenças, estender a aplicação da Convenção 169 da OIT também às populações tradicionais. Com isto, restaria atraído também para estas todo o conjunto de direitos ali consagrados, entre eles, o direito de "gozar plenamente dos direitos humanos e liberdades fundamentais, sem obstáculos nem discriminação" (art. 30, 1); o direito de consulta "mediante procedimentos apropriados e, particularmente, através de suas instituições representativas, cada vez que sejam previstas medidas legislativas ou administrativas suscetíveis de afetá-los diretamente" (art. 60, 1, a); o "direito de escolher suas próprias prioridades no que diz respeito ao processo de desenvolvimento, na medida em que ele afete as suas vida, crenças instituições e bem-estar espiritual, bem como as terras que ocupam ou utilizam de alguma forma, e de controlar, na medida do possível, o seu próprio desenvolvimento econômico, social e cultural (art. 7, 1); a diretriz de "melhoria das condições de vida e do trabalho e do nível de saúde e educação dos povos interessados, com a sua participação e cooperação" como prioridade (art. $7^{\circ}, 2$ ); a determinação de que "os governos deverão zelar para que, sempre que for possível, sejam efetuados estudos junto aos povos interessados com o objetivo de se avaliar a incidência social, espiritual e cultural e sobre o meio ambiente que as atividades de desenvolvimento previstas, possam ter sobre esses povos" (art. $7^{\circ}, 3^{\circ}$ ); ainda, prega a Convenção o direito das comunidades de "conservar seus costumes e instituições próprias, desde que eles não sejam incompatíveis com os direitos fundamentais

\footnotetext{
89 ALMEIDA, Mauro W. Barbosa e REZENDE, Roberto Sanches. Uma Nota sobre Comunidades Tradicionais e Unidades de Conservação. Revista do Centro de Estudos Rurais - UNICAMP 2013. São Paulo. V. 7, n2. Pg. 190.
} 
definidos pelo sistema jurídico nacional nem com os direito humanos internacionalmente reconhecidos" $\left(\operatorname{art.} 8^{\circ}\right)^{90}$.

No que tange especificamente à terra, determinaria a Convenção que "os governos deverão respeitar a importância especial que para as culturas e valores espirituais dos povos interessados possui a sua relação com as terras ou territórios, ou com ambos, segundo os casos, que eles ocupam ou utilizam de alguma maneira e particularmente, os aspectos coletivos dessa relação" (art. 13). À semelhança do que prevê o texto da Constituição Federal de 1988 para os povos indígenas, reconheceria a Convenção "os direitos de propriedade e de posse sobre as terras que tradicionalmente ocupam. Além disso, nos casos apropriados, deverão ser adotadas medidas para salvaguardar o direito dos povos interessados de utilizar terras que não estejam exclusivamente ocupadas por eles, mas às quais tradicionalmente tenham tido acesso para suas atividades tradicionais e de subsistência" (art. 14); a proteção "aos direitos dos povos interessados aos recursos naturais existentes nas suas terras"; o direito a em regra "não serem trasladados das terras que ocupam" (art. 16); e que quando o sejam, excepcionalmente, haja consentimento dos mesmos, ou minimamente representação no procedimento que imponha seu traslado (art. 16, parágrafo $2^{\circ}$ ) bem como o direito de voltar a suas terras assim que as causas que motivaram o traslado deixem de existir (art. 16 , parágrafo $\left.3^{\circ}\right)^{91}$.

A mesma norma asseguraria, também, direitos ligados a Contratação e Condições de Emprego (Parte III); à Seguridade Social e Saúde (Parte V); Educação e Meios de Comunicação (Parte VI); Contatos e Cooperação Através das Fronteiras (Parte VII), entre outros ${ }^{92}$.

Percebe-se da extensa lista o impacto de uma interpretação abrangente da Convenção, sendo ALMEIDA \& REZENDE (2013, pg. 187) eloquentes em apontar sua não efetivação como um dos fatores que explicariam a busca pela via do reconhecimento indígena como forma de ampliação de direitos das populações tradicionais, assim expressando:

\footnotetext{
${ }^{90}$ Brasil. Decreto n ${ }^{\circ}$ 5051/04 de 19 de abril de 2004.

${ }^{91}$ Ibidem.

${ }^{92}$ Ibidem.
} 
Enquanto a contradição flagrante entre as regras do SNUC e o compromisso do Estado Brasileiro para com povos e comunidades tradicionais assumido em tratados e em programas federais não for resolvido, quilombolas e, sobretudo seringueiros, pescadores, caiçaras e outras "comunidades tradicionais" permanecerão privadas de direitos, à mercê de decisões $a d$ hoc tomadas por órgãos públicos separados e baseados em dispositivos legais incompatíveis entre si. Não admira, portanto que muitas dessas comunidades busquem a Fundação Nacional do Índio (FUNAI) como agência pública com mais poderes para assegurar seus direitos ${ }^{93}$.

Ademais das distinções legislativas no tratamento entre as categorias ora contrastadas, também a atuação administrativa do Estado em face destes seria marcada por notável discriminação.

Aos indígenas seriam reservados programas exclusivos de saúde, crédito e moradia, não disponíveis aos tradicionais.

A satisfação de interesses e necessidades pelo Estado é tema que há séculos engendra debates, sobretudo em torno de como se formam as preferências e identidades dos indivíduos na sociedade e como estas se reconformam a partir da atuação daquele. Ao longo da história a evolução do Estado clássico para o moderno teve como um de seus eixos de clivagem a natureza dos interesses e preferências dos cidadãos: se exógenos ao processo público, quando dados, de forma "pré-política"; ou endógenos, isto é, internos à esfera de deliberação e decisão, e, por esta razão, dependente do contexto e das instituições democráticas.

O debate, que em seu cerne não interessa ao objeto do presente trabalho, tendo conduzido à edificação da democracia deliberativa, tem importância aqui, entretanto, na medida em que, conformo afirma BIROLI (2013, pg. 102), “a compreensão de como se definem as identidades e as preferências é um problema central para a crítica da convivência entre democracia e opressão, entre liberdades iguais e formas sistemáticas e violentas de restrição às experiências de parte dos indivíduos nas sociedades organizadas com base em valores e instituições liberais" $"$.

A ideia adotada pelo deliberacionsimo de que as preferencias seriam formadas ao longo do processo de tomadas de decisões, isto é, sendo, portanto, endógenas a ele, faz presumir que as identidades seriam também moldadas, absorvendo as distorções do

\footnotetext{
93 ALMEIDA, Mauro W. Barbosa e REZENDE, Roberto Sanches. Uma Nota sobre Comunidades Tradicionais e Unidades de Conservação. Revista do Centro de Estudos Rurais - UNICAMP 2013. São Paulo. V. 7, n2 pg, 187.

94 BIROLI, Flávia. Autonomia, opressão e identidades: a ressignificação da experiência na teoria política feminista. Revista Estudos Feministas, vol. 21, numero 1, 2013. UFSC
} 
meio, o que revela-se crucial para o presente trabalho, sobrelevando o papel do Estado na formação das identidades, este sim, aspecto que se abordará com maior profundeza nos capítulos abaixo. 


\title{
Cap. 3. A Questão da Identidade Étnica
}

A tentativa de se compreender a origem dos agrupamentos humanos, explicar seus padrões de associação, comportamentos, motiva, desde tempos remotos, a formulação de conceitos que representem uma unidade para tais coletividades. Conforme leciona ATHIAS (2007, pg. 27),

\begin{abstract}
“(...) etnia e étnica têm uma utilização recente nas Ciências Sociais. Em geral, o termo étnico sempre foi utilizado como adjetivo qualificativo de outros termos como: grupo, relações etc. O termo etnia inseriu-se no glossário técnico das Ciências Sociais em oposição ao termo "raça" no intuito de limpá-lo de tudo o que pudesse ser identificado como fruto das teorias racistas ${ }^{95}$.
\end{abstract}

Sua origem remonta ao grego ethnikos, que fazia referência aos povos bárbaros ou aos povos gregos não organizados segundo o modelo da polis. Já no latim, seu correspondente seria o verbete ethnicus, referido aos pagãos, em contraste com os cristãos. Em ambos os casos, significava, assim, o outro, o diferente. Há, porém, nas duas acepções, uma diferença significativa. Enquanto o ethnos fazia referencia à distinção em razão da origem, o ethnicus assentava-se sobre a diferença religiosa ${ }^{96}$.

A utilização da etnia como elemento caracterizador do grupo, representativa de atributos destacados por seus integrantes como relevantes para a comunhão, e diferenciadores do outro, em geral funda-se em um conjunto heterogêneo composto por traços biológicos, origem, história, memórias, costumes, pertencimento a um território, dentre outros.

Se de um lado a noção de raça calcava-se em aspectos biofísicos, a etnicidade se converteria na conjugação tanto daqueles fatores somáticos como, outrossim, de aspectos culturais, simbólicos, sociais, expressando, ao final, "o sentimento coletivo de

\footnotetext{
95 ATHIAS, Renato. A noção de identidade étnica na antropologia brasileira. De Roquette Pinto a Roberto Cardoso de Oliveira. Editora Universitária UFPE. Recife, PE. 2007. Pg,27.

${ }^{96}$ SOUSA, Carlos Jorge dos Santos. Relações Interétnicas, Dinâmicas Sociais e Estrat[egias Identitárias de uma Família Cigana Portuguesa - 1827-1957. Universidade Aberta. Tese de Doutoramento. Março de 2010.pg. 60.
} 
pertencer a um grupo cultural próprio" ${ }^{, 97}$. Em face, destarte, do amplo leque de características é que a etnia passa a substituir, com maior utilidade, a raça como elemento atômico na explicação dos fenômenos sociais. É o que aponta HERRARTE (2006, pg. 111):

\begin{abstract}
"Desde su inicio, las ciências sociales han construído su corpus conceptual y metodológico asumiendo la existência de grupos humanos. Muchos escritos clássicos presentan a dichos grupos como piezas fundamentales de su abstraccion teórica. El entendimento de la conformacion de grupos se propuso como la meta principal del ejercicio acadêmico. Dentro de la teorizacion sobre la etnicidad, el grupo étnico ha sido propuesto como la unidad básica de analisis por muchos de los acadêmicos interessados en el tema." ${ }^{98}$
\end{abstract}

A partir daquela base conceitual, que associava o étnico ao outro, do que distava do conjunto entendido como representativo da sociedade, o termo passou modernamente a associar-se a grupos minoritários, embora originalmente tais conceitos não fossem equivalentes. Neste sentido, assim avalia SOUSA (pg. 61)

\begin{abstract}
A noção de minoria (cf. Streiff-Fenart; Tajfel, 1982; Fernandes, 1998; Rocha-Trindade, 1995) aplica-se, como vimos, numa primeira aproximação, a uma comunidade de indivíduos que compõem um agregado diferenciado menor em oposição a outro, numericamente superior, denominado maioria. Nesta primeira aproximação à problemática, apercebemo-nos de que a mesma é ambígua e redutora e de que contém um elemento-chave que interessa aqui discutir. Trata-se, pois, do conceito de minoria que é relacional: contextualiza-se, compreende-se e explica-se na comparação com os outros grupos; consequentemente, a sua dinâmica, processos, situações e significações só podem ser compreendidos, adequadamente, em referência e contraste com outros agrupamentos, principalmente a maioria ou a denominada sociedade dominante.
\end{abstract}

$\mathrm{O}$ termo minoria refere-se, pois, às especificidades culturais e estilos de vida de certos grupos corporizados em determinados traços culturais, que se diferenciam de outros existentes na sociedade global. $\mathrm{O}$ que significativamente aqui se enfatiza é a diversidade cultural desses grupos em contraste com a cultura dominante, podendo esta diversidade basear-se em distintas singularidades, como é o caso da raça, da religião, da língua, do território, das opções sexuais, dos estilos de vida, entre outras. Neste sentido, fala-se de grupos étnicos (do grego ethos, povo) como um agrupamento de indivíduos com laços culturais, raça ou tradição histórica comuns ${ }^{99}$.

Mais do que o aspecto numérico ou demográfico, a alusão à minoria conotaria, desde a origem, a assimetria de poder dos grupos, enfatizando o aspecto relacional e as estruturas de dominação e de discriminação da sociedade. Esta seria a base para a

\footnotetext{
${ }^{97}$ SOUSA, Ivo Carneiro de. Etnicidade e Nacionalismo: Uma proposta de quadro teórico. Africana Studia. N. 1, 1999. Portugal. Pg. 02.

${ }^{98}$ HERRARTE, Gustavo. Identidade Étnica. Grupos étnicos y otros mitos sobre la etnicidade: interaccióon, cognición y una visión de etnicidad sin grupos étnicos. Revista de la Universidad del Valle de Guatemala. N. 16. 2006. Pg. 111.

${ }^{99}$ SOUSA, Carlos Jorge dos Santos. Relações Interétnicas, Dinâmicas Sociais e Estrat[egias Identit[arias de uma Família Cigana Portuguesa - 1827-1957. Universidade Aberta. Tese de Doutoramento. Março de 2010. pg. 61.
} 
compreensão do conceito moderno: a dialética entre o "nós" e o "outro" em um contexto de assimetrias resultante da construção social, simbólica e histórica, e por esta razão sujeitos a mudanças.

Neste sentido é que novos desafios viriam à tona para a compreensão dos fenômenos étnicos e dos aspectos conformadores dos limites da etnicidade. Os processos históricos que se desenrolariam, dando corpo a uma pluralidade de grupos étnicos, demonstrariam a maior diferenciação das coletividades com fundamento em aspectos culturais e sociais, complexificando o rol de conflitos étnicos e, igualmente, de explicações para tais fenômenos.

Causavam estranheza, por exemplo, as experiências conflituosas de países da África Central e Leste Europeu, onde se veio a notar a afirmação identitária por meio do conflito, ainda que os grupos em confronto possuíssem matrizes étnicas bastante semelhantes ${ }^{100}$. De outra parte, mitos como o de que o isolamento produzia grupos étnicos acabariam por não conferir explicação única, na medida em que se observava que em regiões de contraste, como em fronteiras, os grupos étnicos melhor se definiam ${ }^{101}$. Nestes casos notava-se que “a formulação categórica das identidades étnicas e a mobilização étnica surgiam em situações em que os grupos entravam em contato uns com os outros, muitas vezes especializando ou usando a etnicidade enquanto a ideologia em que tomam forma as diferenças sociais" ${ }^{102}$, levando, SOUSA (2010, pg. 61) a alertar:

"Convoca-se frequentemente o termo 'etnicidade' sugerindo tratar-se de uma categoria
evidente - como ocorria, no passado, com a noção de 'raça' - praticamente natural,
normal e coextensiva com a conflitualidade emergente nos grupos sociais 'etnicamente'
minoritários' ou subalternos. Um exame mais detalhado mostra rapidamente o oposto,
contrariando qualquer evidência, naturalidade ou normalidade no funcionamento da
etnicidade, dissolvendo qualquer explicação em que se procure reconduzir a noção para
o campo das categorias essencialistas vinculadas à natureza humana sub specie
aeternam..."103

${ }^{100}$ SOUSA, Ivo Carneiro de. Etnicidade e Nacionalismo: Uma proposta de quadro teórico. Africana Studia. N. 1, 1999. Portugal. Pg. 110.

${ }^{101}$ BARTH, Frederik. Ethnic Groups and Boundaries. The Social Organization of Culture Difference. Waveland Press. 1969. Pg. 22.

102 SOUSA, Ivo Carneiro de. Etnicidade e Nacionalismo: Uma proposta de quadro teórico. Africana Studia. N. 1, 1999. Portugal. Pg. 110.

${ }^{103}$ Ibidem 
No campo das ciências sociais, debruçar-se-ia WEBER com maior afinco sobre as problemáticas relacionadas à etnicidade, aportando importantes contribuições. Seu pensamento mostra-se ainda hoje complexo, constituindo insumo para maiores reflexões. Em WEBER (1983) enfatizar-se-ia o aspecto subjetivo das relações comunitárias, conferindo importância ao sentimento de pertencimento ao grupo. Não seria, a seu ver, por exemplo, a origem comum, mas a crença nela, o elemento integrador dos membros de um grupo étnico, sendo importantes, por outro lado, hábitos, costumes, memórias, histórias comuns, na medida em que reforçariam a ideia de proveniência única ${ }^{104}$.

Atribui-se a ele a categorização de "comunidade de clã", "comunidade étnica" e "comunidade política", interessando aqui, particularmente, as duas últimas. Contrastando com o conceito de Clãs, entendia o pensador que estes possuíam "agência e multiplicidade de motivos para a ação, enquanto que os grupos étnicos por serem de natureza 'sentimental' não poderiam ser caracterizados como 'coletividades efetivas' ${ }^{105}$. Conforme distinguia,

\begin{abstract}
“como não se trata de clãs, chamaremos grupos 'étnicos' aqueles grupos humanos que, em virtude de semelhanças no habitus externo ou nos costumes, ou em ambos, ou em virtude de lembranças de colonização e migração, nutrem uma crença subjetiva na procedência comum, de tal modo que esta se torna importante para a propagação de relações comunitárias, sendo indiferente se existe ou não uma comunidade de sangue efetiva. A 'comunidade étnica' distingue-se da 'comunidade de clã' pelo fato de aquela ser apenas produto de um 'sentimento de comunidade' e não uma 'comunidade' verdadeira, como um clã, a cuja essência pertence uma efetiva ação comunitária" ${ }^{106}$.
\end{abstract}

Já a comunidade política, que contemporaneamente corresponderia aos EstadosNações, seria "uma comunidade cuja ação social é dirigida para a subordinação de um território e da conduta das pessoas dentro dele à dominação ordeira por parte dos participantes, através da disposição de recorrer à força física, incluindo eventualmente a força das armas" ${ }^{\prime 107}$.

Conforme leciona NASCIMENTO (2003, pg. 39):

\footnotetext{
${ }^{104}$ WEBER, Max. Economia e Sociedade, 1983,

105 HERRARTE, Gustavo. Identidade Étnica. Grupos étnicos y otros mitos sobre la etnicidade: interaccióon, cognición y una visión de etnicidad sin grupos étnicos. Revista de la Universidad del Valle de Guatemala. N. 16. 2006. Pg. 112.

${ }^{106}$ WEBER, Max. Economia e Sociedade. V.I. Brasília: Editora Universidade de Brasília, 1991. Pg. 270.

${ }^{107}$ Ibidem.
} 
Max Weber (1968) percebeu muito bem essa diferença entre comunidade étnica e nação quando se referiu aos russos brancos da Bielorússia. Segundo ele, apesar de a idéia de nação incluir noções de descendência comum como ocorre nas comunidades étnicas, o sentimento de solidariedade étnica por si mesmo não forma uma nação. Os russos brancos, notou Weber (1968), sempre manifestaram um sentimento de solidariedade étnica vis-a-vis seus vizinhos da Rússia, mas não poderiam qualificar-se como uma nação separada. As observações de Weber revelaram-se proféticas, pois até hoje os russos brancos ainda não se constituíram em nação. O colpso da União Soviética obrigou as elites da Bielorrúsia a declararem sua independência e formarem um Estado próprio, mas pesquisas têm indicado que a maioria da população do país não se percebe como essencialmente diferente dos russos e há forte respaldo popular para uma reunificação com a Rússia (Urban e Zaprudnk, 1993). Nesse sentido, a Bielorússia, já um Estado, é uma nação ainda em potencial. ${ }^{108}$

$\mathrm{O}$ autor distinguia o elemento étnico do racial, não sendo suficiente a especialização biológica em si para a formação do grupo étnico. Mais do que as características físicas ou mesmo culturais, seria necessário que estes invocassem o entendimento subjetivo destes caracteres, pelo que os partilhavam.

A existência de uma "comunhão étnica", como denominado por WEBER (1983), não acarretaria, necessariamente, o surgimento de uma "comunidade étnica", constituindo apenas um de seus elementos, facilitador, por certo, das relações entre os membros. Por sua vez, a existência de uma comunidade de cunho político estimularia a crença em uma comunhão étnica, ainda que fundada em uma estrutura artificial. Neste movimento, esclarece, poderiam as comunidades provocar sentimentos de comunhão que subsistiriam mesmo após o desaparecimento daquelas, sendo percebidos os laços daquela agremiação como "étnicos".

A par da eventual língua comum ou religiosidade, ou mesmo de uma memória histórica, o traço étnico de uma comunidade seria, marcado, outrossim, pela noção intrudizida pelo autor de habitus exteriormente manifestados. Naturalmente, língua e religião, assim como fatores econômicos desempenhariam não só um papel importante na crença de afinidade étnica, como ocasionariam e sustentariam as diferenças de costumes. Sem embargo, com certo tom de ceticismo, afirmava o autor a dificuldade em encontrar sociedades com habitus sobremaneira distintos daquelas adjacentes, sem uma transição gradual entre elas, a menos que se falesse em migrações ou expansões, ou mesmo se estivesse diante barreiras geográficas. ${ }^{109}$

108 NASCIMENTO, Paulo César "Dilemas do nacionalismo" Revista Brasileira de Informação Bibliográfica em Ciências Sociais (BIB) 56. São Paulo: ANPOCS, 2003. Pg. 39.

${ }^{109}$ WEBER, Max (2000) [1915-1921]. “Relações Comunitárias Étnicas”. In: Economia e Sociedade. Vol. 1. Brasília: Editora da UNB, p. 274. 
Outra importante circunstância seria a ação comunitária em busca de "destinos políticos comuns", vis-à-vis à "procedência comum". Ou seja, a ação comunitária política geraria a "comunidade de sangue" sob a "crença na pertinência a um mesmo grupo étnico" $" 110$.

No entender do autor, elementos que constituiriam o patrimônio hereditário e o patrimônio tradicional teriam, ambos, condições de persistência e reprodução nas comunidades, sustentando iguais "efeitos comunizantes". A diferença entre eles residiria, entretanto, no fato de que o patrimônio hereditário teria maior estabilidade e rigidez, enquanto os elementos da tradicionalidade transmitir-se-iam, e modificar-seiam com maior facilidade. É o que se vê do trecho:

“... la creencia en el parentesco de origen - siendo indiferente que sea o no fundada puede tener consecuencias importantes, especialmente para la formación de la comunidade politica. Llamaremos "grupos étnicos" a aquellos grupos humanos que, fundándose en la semejanza del hábito exterior y de las costrumbres, o de ambos a la vez, o en recuerdos de colonización y migración, abrigan una creencia subjetiva en una precedência común, de tal suerte que la creencia es importante para la ampliación de las comunidades; per la designaremos así simpre que no representen "clanes", aunque sin tener encuenta si existe o no una verdade comunidade de sangre. La colectividad "étnica"se distingue del "clan" en que, en si misma, no es más que una "colectividad"o grupo (creído) y no "comunidade"efectiva como el clan, a cuya esencia pertenece una acción comunitária efectiva. El grupo étnico (en el sentido en que aqui se toma) no es en sí mismo una comunidade si no tan sólo un momento que facilita el processo de comunicación. ${ }^{111}$

Já no século XX, BOURDIEU (1994, pg. 108) mostrar-se-ia igualmente atento ao tema, chamando a atenção para as "propriedades subjetivas" da etnicidade, como o sentimento de pertencimento ao grupo, a elas somando aquelas de caráter objetivo, como o território, ascendência, língua, religião, entre outras. A estas duas dimensões, entretanto, agregava o autor uma terceira, atinente às representações que os indivíduos têm das clivagens sociais. ${ }^{112}$

Modernamente, a etnicidade tem sido compreendida não mais como uma característica do grupo, senão como um tipo relacional, isto é uma interação entre agentes étnicos. É o que afirma GÓIS ao apontar que,

\footnotetext{
${ }^{110}$ Ibidem.

${ }^{111}$ WEBER, Max. Metodologia das Ciências Sociais, Parte 2. Tradução Augustin Wernet; Introdução à edição brasileira Maurício Tragtenberg. São Paulo: Cortez; Campinas, SP: Editora da Universidade Estadual de Campinas, 1992. Pg. 318.

112 Bourdieu, P. ([1994] 1997). Razones prácticas - Sobre la teoría de la acción. Barcelona: Editorial Anagrama. Pg. 108.
} 
"etnicidade" per si e isolada não existe mas, aparentemente, existem "etnicidades contextuais". Dito de outro modo, a "etnicidade" de cada um apenas se torna manifesta quando ocorre um contacto com outros "grupos étnicos" pelo que não é uma característica importante numa sociedade mono-étnica. Onde há uma minoria haverá uma maioria e na ausência de uma definição desta última, a primeira também tende a desvanecer-se ${ }^{113}$

Mas se de um lado indaga-se - especialmente no capítulo abaixo -, como os indíviduos se comunitarizam, formando grupos e nações, de outra parte despertaria interesse a relação do grupo enquanto criador de estruturas socializadoras, que condicionam as identidades individuais. Em outras palavras, como a sociedade edifica as pessoas?

Abaixo aprofundar-se-á a evolução teórica acerca do tema, a qual vem direcionando-se, em seu curso, para a compreensão da etinicidade como fluida, admitindo-se a autenticidade de reconformações identitárias.

113 GÓIS, Pedro Manuel Rodrigues da Silva Madeira e. A construção secular de uma identidade étnica transnacional: a cabo-verdianidade. Tese de doutoramento. Universidade de Coimbra. Portugal. 2011. Disponível em https://estudogeral.sib.uc.pt/bitstream/10316/17848/1/tese\%20versão\%20final.pdf. (Consulta realizada em 19/11/2015.) 


\section{Cap. 3.1. Primordialismo, Instrumentalismo, Construtivismo}

Ao longo da história a interpretação dos fenômenos identitários deu origem a duas grandes correntes de pensamento, o primordialismo e o circunstancialismo, esta última subdividida em pelo menos duas vertentes principais, em razão de particularidades que as distanciavam, o instrumentalismo e o construtivismo, cada uma delas com diversas outras variantes. Se bem que estas teorias tiveram como impulso a compreensão do nacionalismo ${ }^{114}$, seu foco se dava nos aspectos identitários em torno das nações, prestando, assim, grande contribuição aos debates aqui enfrentados.

A par das características da etnicidade, expressas pelas teorias supracitadas, seus partidários evidariam esforços, complementarmente, no sentido de explicar o momento de surgimento do nacionalismo, daí surgindo a dicotomia entre modernistas e aqueles que o viam como um fenômeno imemorial, chamados perenialistas, debates que em parte se confundem, porém que se ocupam de aspectos distintos. Para o presente trabalho mantém-se o foco naquela primeira questão, ainda que entre elas haja interseções.

Segundo o postulado primordialista, os indivíduos teriam com a coletividade um vínculo primordial, o que seria determinante para a identidade coletiva. A etnicidade seria atributo da essência humana, herança de elementos de natureza somática e assomática. Embora a defesa da primordialismo varie segundo o peso conferido aos elementos biológicos e aos contextuais, coincidem seus partidários quanto à base

\footnotetext{
${ }^{114}$ Neste sentido, afirma SOUSA: Um aspecto importante da discussão em torno das identidades estabelece-se no contexto da construção dos Estados nacionais. Uma das características mais relevantes desse tipo de identidade é o facto de ele se construir a partir de elementos culturais facilmente universalizáveis, fazendo coincidir simbolicamente uma cultura, um território e uma forma de organização política (Gellner, 1983; Hobbsbawm, 1998). As identidades nacionais são fruto de uma construção que se desenvolve no sentido da formatação das diferenças e das singularidades. Hall questiona o carácter fixo e unitário. SOUSA, Carlos Jorge dos Santos. Relações Interétnicas, Dinâmicas Sociais e Estratégias Identitárias de uma Família Cigana Portuguesa - 1827-1957. Universidade Aberta. Tese de Doutoramento. Março de 2010. pg. 55.
} 
essencial irrenunciável das identidades, que independeria, assim, da interação com outros grupos. Dentre seus expoentes, SMITH (2000, pg. 5) assim definiu:

\begin{abstract}
"O termo primordialismo é relativamente recente, e usado de várias formas. Muito comumente é utilizado de forma pejorativa. Em termos gerais, a expressão se refere à ideia de que certos atributos e formas culturais possuem influência a pirori, obrigatória, e determinante sobre as vidas das pessoas; [esta influencia] tem imunidade frente aos interesses 'racionais' e cálculos políticos. Em certo sentido, nós estamos afetados por vínculos que emanam destes atributos e formações [culturais]. Estes [vínculos] existem fora e sobre as opções racionais e à obtenção de interesses materiais que caracterizam muito de nossa vida. Entre estes vínculos, aqueles que se derivam de atributos culturais como parentesco, linguagem, religião e costumes, assim como também territórios históricos, assumem um lugar importante, tendem a viabilizar um sentimento de pertencimento comunal que nós chamamos etnicidade e comunidade étnica. Também permitem o desenvolvimento subsequente de nações e nacionalismos. Por estas razões, nações e nacionalismos possuem uma característica especial e ocupam lugares privilegiados em nossa história; neste sentido posem ser chamados primordiais, já que existem antes da história ${ }^{115}$
\end{abstract}

Em "The Antiquity of Nations", interessado nas condições que propriciariam o surgimento do nacionalismo, disserta Smith acerca do mito da Nação Moderna, também associado ao primordialismo, segundo o qual a humanidade seria naturalmente dividida em nações, cada uma com características particulares, devendo os indivíduos pertencer necessariamente a uma delas. As nações existiriam desde tempos remotos, ainda que em muitos casos os membros da maioria delas tenham esquecido suas identidades e falhado em reconhecer as ligações que os uniriam ${ }^{116}$.

O autor faz a ressalva ao dizer que as nações modernas são construídas sobre fundações étnicas, no sentido de que tal não significaria que toda nação emerge sobre uma etnia primordial, mas sim que as primeiras nações, que serviram de modelo para as seguintes, possuíam tal base. Estes modelos se tornaram populares. Há, assim, uma crença profunda na vitalidade e importância do passado. Ao final o mito da origem é que ligaria a nação moderna à etnia.

A importância conferida às características ancestrais levaria, na visão da corrente primordialista, a uma relativa estabilidade da etnicidade, que se modificaria apenas lentamente, podendo passar por períodos de dormência e retornar à tona segundo estímulos do meio.

\footnotetext{
115 SMITH, Anthony. "O Nacionalismo e os Historiadores". In. Gopal Balakrishnan (org.) Um Mapa da Questão Nacional. Contraponto: Rio de Janeiro. 2000. Pg. 2005

${ }^{116}$ SMITH, Anthony. The Antiquity of Nations. Wiley, 2004. Pg. 7.
} 
Da mesma forma como a etnicidade seria um elemento natural, os conflitos étnicos também o seriam na visão de primordialistas, dada a origem imutável do sentimento étnico.

Ao longo dos anos o primordialismo tornar-se-ia - e manter-se-ia - útil em reconhecer a heterogeneidade da humanidade, o que atribuía à rigidez daquelas fronteiras étnicas ${ }^{117}$. Conforme bem resumia o Exemplar da Economist de maio de 2015, "If you are born poor, you may die rich. But you ethnic group is fixed"118

Da relativa dificuldade, entretanto, de explicação de alguns fenômenos étnicos através da concepção primordialista, levantaram-se de outra parte correntes que viriam a ser englobadas sob o rótulo de circunstancialistas: construtivistas, instrumentalistas, transacionistas, dentre outras vertentes, para as quais a etnicidade não seria um dado, senão o resultado de arranjos sociais, "uma transação simbólica entre agentes interativos. Etinicidade não é a soma de diferenças em diacrítica objetiva (leia-se cultura), senão uma relação onde se sublinha distinta diacrítica para indicar diferença". 119

Com efeito, não oferecia o primordialismo uma explicação satisfatória sobre a fluidez das fronteiras étnicas, a forma como novas identidades eram construídas no novo mundo, entre outras questões que vinha à tona. Casos concretos como o massacre em Ruanda, por exemplo, colocaria em cheque pressupostos primordialistas. No nefasto episódio, as categorias Hutu e Tutsi não se edificavam historicamente sobre aspectos exclusivamente biológicos. A noção que gerou o conflito posteriormente entre as duas etnias africanas fora posteriormente introduzida pelos colonizadores europeus, invalidando as interpretações lastreadas no essencialismo étnico.

Apesar disto, alguns postulados primordialistas seguiriam atrativos, especialmente ao senso comum, lastreando ainda hoje a compreensão da diversidade

\footnotetext{
${ }^{117}$ FREEMAN, Diane. An Explanation of Conflict: Ethnicity, Deprivation, and Rationalization. Kentucky Political Science Association Conference. 2015. Pág. 01.

118 Traduzindo: Se você nascer pobre, poderá morrer rico. Mas o seu grupo étnico permanecerá fixo". The Economist, Maio, 2005, pg. 80.

119 HERRARTE, Gustavo. Identidade Étnica. Grupos étnicos y otros mitos sobre la etnicidade: interaccióon, cognición y una visión de etnicidad sin grupos étnicos. Revista de la Universidad del Valle de Guatemala. N. 16. 2006. Pg. 17.
} 
étnica como um "problema", muitas vezes insuperável em face da rigidez dos grupos e de sua propensão ao conflito.

Tem-se considerado como marco para a guinada circunstancialista o ensaio de BARTH (1969), por meio do qual se acrescentou a ideia de fronteiras étnicas - que poderiam ser territoriais ou não - dentro das quais os grupos teriam autoconsciência de suas identidades, reforçando-as ${ }^{120}$.

O autor em sua obra chamaria a atenção para dois aspectos condicionais da materialidade da etnicidade, fatores ecológicos e demográficos. Os primeiros seriam aqueles que organizam, decidem ou influenciam as opções étnicas dos indivíduos, enquanto os fatores demográficos diriam respeito à possibilidade de trânsito entre os grupos.

Mais significativa, entretanto, seria a contribuição do autor em afirmar que os grupos étnicos não se estruturariam sobre elementos culturais comuns, ou em razão de sua especificidade. Ao contrário, organizar-se-iam com fundamento na interação social, quando ativariam as características do grupo segundo um contexto específico. Isto é, os agentes adotariam uma identidade em razão das oportunidades dipostas, do ambiente e dos grupos em contato, assim definindo o que chamava de padrões de existência e formas de conduta. ${ }^{121}$

Desta abordagem surgiria uma nova clivagem no seio dos estudos sobre etnicidade, entre essencialistas e anti-essencialistas. No cerne deste debate estaria a existência ou não de um conteúdo essencial, autêntico, original, intrínseco à etnicidade, o que negavam os anti-essencialistas, dentre eles o próprio precursor, enxergando as identidades sempre como relacionais e incompletas. ${ }^{122}$

Assentada sobre tais premissas seria edificada corrente então intitulada instrumentalista, segundo a qual as identidades seriam fluidas, maleáveis, mutáveis, e, sobretudo, manipuláveis pelas elites. Não seriam, destarte, conflituosas por natureza,

\footnotetext{
${ }^{120}$ BARTH, Frederik. Ethnic Groups and Boundaries. The Social Organization of Culture Difference. Waveland Press. 1969.

${ }^{121}$ Carlos Jorge dos Santos. Relações Interétnicas, Dinâmicas Sociais e Estratégias Identitárias de uma Família Cigana Portuguesa - 1827-1957. Universidade Aberta. Tese de Doutoramento. Março de 2010. pg. 74.

${ }^{122}$ Ibidem, pg. 59.
} 
mas por ação de agentes interessados em obter proveito da ação política dos grupos étnicos. Sua defesa mais enfática seria aquela capitaneada por WEBER $(1991)^{123}$ acima já citado -, para quem a etnicidade seria um fenômeno social, e não natural, resultado de um processo de socialização sob pressão das elites. BRANCO (2006, pg. 2) sintetiza tal ponto de vista da seguinte forma,

\begin{abstract}
"Segundo Weber, são grupos étnicos aqueles grupos humanos que partilham uma crença subjetiva na sua descendência comum devido a semelhanças de natureza física ou de costumes, ou de ambos, ou ainda devido a memórias de colonização e migração. Esta crença pode ser importante para a formação do grupo, não interessando se existe ou não uma relação sanguínea objetiva entre os seus membros. A ênfase colocada por Weber numa identidade presumida como o principio estruturante da unidade étnica não implica, contudo, qualquer consequência particular no domínio da ação social e política.

$\mathrm{O}$ facto de se pertencer a uma etnia não significa automaticamente a existência de um grupo étnico apenas facilita a sua formação qualquer que seja a sua natureza, particularmente na esfera politica. A noção de ação social etnicamente motivada faz parte de um fenômeno, que uma análise sociológica rigorosa tem de saber distinguir cuidadosamente.
\end{abstract}

A consciência étnica forma-se primariamente através de experiências políticas comuns, não importando o quão artificial seja a organização politica da comunidade. Weber abre a porta para a possibilidade da etnicidade ser criada, mesmo apenas através da imaginação coletiva de indivíduos aparentemente semelhantes. O papel fundamental da política implica que a etnicidade como um fenômeno se torne real apenas devido às circunstâncias, e não porque exista a priori como qualquer solidariedade instrinsecamente permanente, ligando um conjunto de indivíduos através do tempo e do espaço" ${ }^{124}$.

Importante segundo os instrumentalistas seria, destarte, a ideia de que a etnicidade seria uma escolha individual, e não atribuída, como crê o primordialismo. $\mathrm{O}$ conflito, por sua vez, seria o produto da "politização" do grupo étnico, o resultado de uma competição social, e não uma tendência ou propensão inata.

Nesta esteira, resumiu BRANCO (2006, pg. 03),

“A etnicidade é primeiro e acima de tudo um rótulo ou um conjunto de laços simbólicos que são usados para se obterem vantagens politicas, exatamente como acontece com as filiações em grupos de interesses ou em partidos políticos ${ }^{125}$ ", embora sua utilização pelas elites fique limitada pelas crenças e valores que conseguem utilizar na mobilização. Autores citam, a sustentar esta tese, o insucesso de mobilizações sob a tentativa de promoção de identidades, como ocorrido no sul da França nos anos 60, em que se invocava a identidade "Ocitânica", ou no norte da Italia, com a identidade "Padânica".

\footnotetext{
${ }^{123}$ WEBER, Max. Economia e Sociedade. V.I. Brasília: Editora Universidade de Brasília, 1991.

${ }^{124}$ BRANCO, Carlos Manuel Martins. Etnicidade e Violencia Etnica. Revista Militar, novembro de 2006, pg. 2.

${ }^{125}$ Ibidem, pg. 3.
} 
Em face do instrumentalismo, três críticas principais ganharam destaque, o que fomentaria o surgimento de subdivisões a contorná-las. A primeira dizia respeito a um suposto subdimensionamento do aspecto afetivo da etnicidade, desaguando na dificuldade da corrente de explicar a grande carga emocional que paira sobre os conflitos interétnicos. Segunda crítica afirmaria que os instrumentalistas, de sua parte, tendem a superestimar a racionalidade das preferências, em prejuízo do papel do ambiente onde ocorrem as competições. Por fim, uma terceira crítica principal, sintetizando as duas primeiras, afirmaria que tal corrente supervalorizaria a competição por recursos materiais, negligenciando o papel dos sentimentos étnicos.

A partir delas, pelo menos três vertentes de pensamento distintas ganhariam destaque. Dentre elas, o estruturalismo, cujos defensores, nas palavras de BRANCO (2006, pg. 06),

\begin{abstract}
"tendem a ignorar completamente a variável cultura na equação étnica, argumentando que a etnicidade não é politicamente relevante nem serve para explicar a conflitualidade social. A organização social é definida pela posição dos grupos sociais no modo de produção capitalista e o conflito social é explicado pelo antagonismo de classe, e não por diferenças com base na religião, raça ou cultura. A raça e os grupos étnicos funcionam apenas como meras "mascaras" que são utilizadas para obscurecer a identidade de classe, na luta pelo poder político ou econômico. Os estruturalistas consideram os grupos de base comunitária apenas como mais uma entrada na lista de grupos orgânicos das suas tabelas de "sistemas políticos"
\end{abstract}

Assim é que para os estruturalistas o conflito preponderante seria o de classe, sendo a etnicidade um fator subsidiário. Sua inserção no âmbito do instrumentalismo se daria em razão da instrumentalização da etnicidade como recurso à luta de classes. As classes desempenhariam o papel das elites dos instrumentalistas. As criticas ao estruturalismo vão na direção de que a corrente somente poderia ecoar em sociedades onde classes e etnias coincidissem suas fronteiras. A contribuição do estruturalismo estaria, de toda forma, em reforçar a busca dos grupos por recursos, enfatizando o conflito político que caracteriza o conflito étnico.

Também, ganhou corpo como variante instrumentalista vertente denominada racionalista, considerando os comportamentos individuais o resultado da interação de constrangimentos estruturais com as preferencias soberanas dos indivíduos. A estrutura determinaria em um primeiro momento as regras comportamentais dos indivíduos, cujas

\footnotetext{
${ }^{126}$ BRANCO, Carlos Manuel Martins. Etnicidade e Violencia Etnica. Revista Militar, novembro de 2006, pg. 6.
} 
escolhas seriam adotadas de forma racional. Os indivíduos adaptariam assim os meios aos fins. Em outras palavras, a escola racionalista sustenta que os indivíduos se agrupam para atuar coletivamenteb com fincas na maximização dos resultados de suas ações, fazendo uso das ações étnicas conforme seus interesses individuais. Trata-se, em última instância, da aplicação da teoria da escolha racional às relações raciais e étnicas.

Ainda no âmbito do Instrumentalismo, surgiria variante denominada Institucionalista, para a qual os conflitos teriam gênese no enfraquecimento do contrato social e das instituições de Estado.

Mais recente entre as linhas de pensamento, emergiu, atraindo com entusiasmo grande número de adeptos, o construtivismo, a partir, sobretudo, de trabalhos de ANDERSON - especialmente Comunidades Imaginadas (2008) ${ }^{127}$-; e de HOBSBAWN e RANGER (1997) ${ }^{128}$ - Invenção da Tradição -, pregando que um grupo étnico seria, sobretudo, uma comunidade imaginada. Tais obras representariam importante contribuição contra o essencialismo que historicamente dominava as ciências sociais.

Tendo foco nos fenômenos nacionais, e interessados em precisar o momento de surgimento do nacionalismo, defenderiam estes autores que o nacionalismo estaria ligado à passagem da sociedade agrária para a industrial. A industrialização e a urbanização, a formação de uma burocracia nacional e a consolidação do poder de novas elites politicas sobre territórios definidos exigiam uma ideologia, uma cultura comum e uma língua única, que somente o nacionalismo poderia proporcionar. $\mathrm{O}$ processo de formação nacional é acelerado pela introdução de um sistema educacional de massas e um código cultural popular disseminado pelos meio de comunicação.

Em Comunidades Imaginadas investigava ANDERSON (2008) o surgimento do sentimento nacional que confluía para a formação dos Estados nacionais, a partir de inquietações, como a explosão de guerras de eminente caráter nacionalista entre países socialistas. Ainda, intrigava o autor o surgimento de sub-nacionalismos em um mesmo território, o reconhecimento de novas nações, dentre outras questões ${ }^{129}$.

\footnotetext{
${ }^{127}$ ANDERSON, Benedict: Comunidades Imaginadas. São Paulo. Cia das Letras, 2008.

${ }^{128}$ HOBSBAWM, E.; RANGER, T. (Org.). A invenção das tradições. Rio de Janeiro: Paz e Terra, 1997.

${ }^{129}$ ANDERSON, Benedict: Comunidades Imaginadas. São Paulo. Cia das Letras, 2008.
} 
Suas investigações apontavam, ao final, para o nacionalismo como um produto circunstancial - rechaçando, assim, a ideia central dos primordialistas de uma nacionalidade natural - sem embargo de perceber certas características do nacionalismo como primordiais, como a língua, pelo fato de não se poder precisar quando surgiu, criando uma ligação continua com o passado. Por esta razão a língua seria o mais enraizado dos elementos étnicos. Desta forma é que seria a nação uma comunidade imaginada e limitada. $\mathrm{O}$ uso da expressão imaginada faria alusão a que seus membros percebem um vínculo entre eles ainda que não se conheçam ou venham a se conhecer. Limitada, a seu turno, significaria que os membros embora não se conheçam, bem compreendem suas fronteiras, isto é, identificam os membros dessa comunidade e os que a ela não pertencem.

O autor alertava quanto ao conteúdo da expressão invenção, tecendo críticas à sua equiparação com fabricação, bem como à aproximação de "imaginação" com “criação". Afinal, como afirma o próprio estudioso, "as comunidades não devem se distinguir por sua falsidade ou legitimidade, senão pelo estilo como são imaginadas"130.

Também PANTOJA (2011, pg. 126) assim afirmava sobre a acusação de falsidade de grupos étnicos:

Talvez parte da dificuldade de escapar às antinomias entre "autenticidade étnica" e "invenção de tradições" venha da conceitualização que define "grupos étnicos" como "forma de organização social", mas sem recurso à complexidade das diferentes formas de "comunitarização".

Essa conceitualização restritiva talvez tenha origem em uma leitura excessivamente funcionalista de Weber, por parte de Fredrik Barth (2000), ou de seus repetidores. Nessa leitura, põe-se em segundo plano as "crenças em algo comum" como fundamento da ação comunitária (tradicional ou afetiva), sejam elas referentes a uma "ancestralidade comum", sejam referentes a "destino comum", sejam referidas a um habitus percebido como igualmente comum, retendo-se as "regras que governam os encontros sociais interétnicos" Nisso, no limite, os "traços diacríticos" passam a ser vistos como manobras de um jogo de estratégia ${ }^{131}$.

E, ainda, segundo a autora:

Os traços diacríticos, eleitos num contexto político, precisam ser capazes de operar contrastes, e, nesse sentido, a etnicidade opera como uma linguagem ( CUNHA, 1987, p. 97-108). Contudo, dito isso, as diferenças “culturais" que serão invocadas num contexto de demarcação de diferenças e busca por direitos, são imprevisíveis: elas serão

\footnotetext{
${ }^{130}$ ANDERSON, Benedict: Comunidades Imaginadas. São Paulo. Cia das Letras, 2008, pg. 24.

${ }^{131}$ PANTOJA, Mariana C., COSTA, E. M. L \& ALMEIDA, M. W. B. de 'Teoria e prática da etnicidade no Alto Juruá Acreano. Revista Raízes, v.31, 2011. Pg. 126
} 
convocadas a partir de um repertório que depende da tradição local, da vizinhança, e da capacidade de invenção.

Carneiro da Cunha chama atenção, assim, para o fato de que, embora grupos étnicos não sejam explicáveis pela cultura, "a cultura entra de modo essencial na etnicidade" (Idem p. 101). Mais recentemente, ainda lidando com o caráter irredutível da cultura, Cunha (2009, p. 311-373) chamou a atenção para a coexistência da cultura e da "cultura", distinção que pode ser interpretada como a que existe entre o domínio do que temos chamado, seguindo Weber, de habitus e "disposições", e o das marcas externas usadas em contextos interétnicos para expressar reivindicações políticas e econômicas. ${ }^{132}$

Para ANDERSON (2008, pg. 61), somente a reunião no tempo de um conjunto de características específicas teria permitido aos indivíduos imaginar as nações: um língua escrita, a crença em uma sociedade organizada em torno de centros de poder; a necessidade de uma fraternidade que substituísse a antiga comunhão pela submissão aos antigos soberanos, tendo o capitalismo cumprido tal papel unificador. A possibilidade de se imaginar as nações somente teria tornado possível, assim,

"quando três concepções culturais fundamentais, todas elas muito antigas, perderam seu controle axiomático sobre as mentes dos homens. A primeira era a ideia de que uma língua escrita particular oferecia um acesso privilegiado à verdade ontológica, precisamente porque era uma parte inseparável dessa verdade. Foi esta ideia que criou as grandes irmandades transcontinentais do cristianismo, do islam e todas as demais. A segunda era a crença de que a sociedade estava naturalmente organizada ao redor e sob centros elevados: monarcas que eram pessoas diferentes dos demais seres humanos e governavam mediante alguma forma de dispensa cosmológica (divina). As lealdades humanas eram necessariamente hierárquicas e centrípetas porque o governante, como a escritura sagrada, era um nó de acesso ao ser e algo inerente a ele. A terceira era uma concepção da temporalidade onde a cosmologia e a história eram indistinguíveis, enquanto que a origem do mundo e do homem eram idênticas na essência. Combinadas, estas ideias arraigavam firmemente as vidas humanas à natureza mesma das coisas, dando certo sentido às fatalidades da existência de todos os dias (sobretudo a morte, a perda e a servidão), e oferecendo, em diversas formas, a redenção de tais fatalidades ${ }^{133}$.

E ainda, para o teórico,

"O declínio lento e irregular dessas convicções mutuamente entrelaçadas, primeiro na Europa Ocidental e depois em outros lugares, sob o impacto da transformação econômica, das descobertas (sociais e cientificas) e do desenvolvimento de meios de comunicação cada vez mais velozes, levou a uma brusca clivagem entre cosmologia e historia. Desse modo, não admira que se iniciasse a busca, por assim dizer, de uma nova maneira de unir significativamente a fraternidade, o poder e o tempo. O elemento que talvez mais catalisou e fez frutificar essa busca foi o capitalismo editorial, que permitiu que as pessoas, em números sempre maiores, viessem a pensar sobre si mesmas e a se relacionar com as demais de maneiras radicalmente novas ${ }^{134}$.

\footnotetext{
${ }^{132}$ Ibidem, pg. 127.

${ }^{133}$ ANDERSON, Benedict: Comunidades Imaginadas. São Paulo. Cia das Letras, 2008, pg. 61

${ }^{134}$ Ibidem, pg. 62
} 
Todo esse trabalho de engenharia social seria necessário, na visão de GELLNER (1964, p. 169), porque 'o nacionalismo não é o despertar das nações à autoconsciência; ele inventa nações onde elas não existem ${ }^{135}$.

HOBSBAWN (2000, pg. 272), de sua parte, enfatizaria justamente este ponto crucial da tese modernista: nações são construções, invenções humanas, que não existiram desde tempos imemoriais, como reivindicam alguns ideólogos do nacionalismo, mas que surgiram em um determinado contexto geográfico, socioeconômico e politico, que ele identifica como sendo a revolução francesa, a ascensão da burguesia e das classes medias, e o surgimento de mercados nacionais na Europa. ${ }^{136}$

Segundo o mesmo autor,

"O nacionalismo é um projeto político e, em termos históricos, bastante recente. Ele afirma que os grupos definidos como 'nações' têm o direito de formar e devem formar Estados territoriais do tipo que se tornou padrão desde a Revolução Francesa. Sem esse projeto, realizado ou não, 'nacionalismo' é uma palavra vazia. Na prática, o projeto geralmente significa exercer o controle soberano sobre uma faixa territorial tão contínua quanto possível com fronteiras claramente definidas e habitadas por uma população homogênea, que compõe seu corpo essencial de cidadãos. Ou, antes, de acordo com Mazzini, ele inclui a totalidade dessa população: 'A cada nação um Estado, e apenas um Estado para a nação inteira'. Dentro desses Estados, uma única língua, a da 'nação' de que se trata, é dominante, ou melhor, goza da condição ou monopólio oficial privilegiado. Observo de passagem que, provavelmente, das cento e setenta e poucas entidades políticas do mundo, apenas cerca de uma dúzia se conforma à primeira metade do projeto mazziniano, se definirmos as nações em termos etnolinguísticos." ${ }^{137}$

A circunstância seria também descrita com clareza para autores como FREEMAN (2015, pg. 24), para quem a etnicidade seria real, but constructed ${ }^{138}$, ou um state of mind $^{139}$.

Com a evolução dos estados-nações acreditava-se, entretanto, que estes substituiriam formas mais restritas de agrupamento, conforme afirmou SOUSA, "fazendo-se, assim, com que, ao longo deste processo, diminuísse também a

${ }^{135}$ GELLNER, Ernest (1964) Thought and Change, Londres, Weidenfeldand Nicolson, p. 168 citado em HUTCHINSON, 1994. Pg. 169.

${ }^{136}$ HOBSBAWN, Eric. Nations and Nationalism. Cambridge University Press. Cambridge, 1990.

${ }^{137}$ HOBSBAWM. Eric J. "Etnia e Nacionalismo na Europa de Hoje", In "Um Mapa da Questão Nacional”, organização Gopal Balakrishnan. Ed. Contraponto. 2000. Rio de Janeiro, RJ. pg 272.

${ }^{138}$ Traduzindo: Real, porém construída”. FREEMAN, Diane. An Explanation of Conflict: Ethnicity, Deprivation, and Rationalization. Kentucky Political Science Association Conference. 2015. Pág. 24.

139 Traduzindo: Um estado da mente. SALEH, Alam. Relative Deprivation Theory, Nationalism, Ethnicity and Identity Conflicts. Geopolitics Quarterly, Vol. 8. Pg. 158 
importância da etnicidade em benefício da identificação com o Estado-nação, forjando o que se passou a agitar como a identidade nacional". ${ }^{140}$

$\mathrm{O}$ que se viu, entretanto, no decorrer do século $\mathrm{XX}$, foi o levante de regionalismos, movimentos separatistas, guerras e genocídios, frequentemente fundados em diferenças étnicas.

A tentativa de explicar tais acontecimentos levaria à classificação dos nacionalismos em três distintas formas: etnonacionalismo, nacionalismo cívico e nacionalismo sincrético, segundo a relação com o aspecto étnico. Na explicação de SOUSA (1999, pg. 117),

"O primeiro assentado e exagerando a cidadania enquanto fator primordial de identidade social nacional, enquanto o nacionalismo étnico seria quase herdado, uma espécie de característica genética que se foi colando com algum sucesso político aos processos actuais de 'limpeza', territorialização ou divisão de poderes que se pretendem baseados na etnicidade. Por isso, o apelo para uma etnicidade comum, praticamente genética e natural, logo inevitável em termos de identidade cultural também comum, é geralmente utilizado pelos líderes e movimentos políticos como fator de coesão e mobilização sociais. Deste modo, as relações entre etnicidade e nacionalismo podem permanecer apenas latentes durante anos e subitamente reemergir com inesperado vigor, como se assiste hoje dramaticamente do Ruanda à antiga Jugoslávia. ${ }^{141}$

Assim como o instrumentalismo, o construtivismo também se subdividiria, a partir de sua gênese, em uma miríade de outras correntes com particularidades sobre sua base ideológica única. Também à semelhança do instrumentalismo, o construtivismo consideraria as identidades étnicas como construções, fruto de fenômenos sociais, sendo, por isto, mutáveis, fluidas, e não um dado natural, da mesma forma, não constituindo uma fonte natural de conflitos, como pregam primordialistas. A explicação pra o fenômeno é que variaria entre uma e outra corrente de pensamento. Se de um lado os instrumentalistas entendem que a etnicidade seria resultado da manipulação das elites, os construtivistas alegam que o processo de construção das identidades seria uma equação muito mais complexa. Na explicação de BRANCO (2006, pg. 13),

\footnotetext{
"Para os construtivistas, a etnicidade é o produto de uma densa rede de interações sociais. Do modo como se desenvolvem estas interações sociais, assim se desenvolve o processo de identidade grupal. A etnicidade e as suas manifestações politicas não podem ser analisadas no vácuo histórico. Pelo contrário devem ser estudadas num contexto mais alargado de prolongadas relações históricas, culturais e ambientais.
}

${ }^{140}$ SOUSA, Ivo Carneiro de. Etnicidade e Nacionalismo: Uma proposta de quadro teórico. Africana Studia. N. 1, 1999. Portugal. Pg. 117.

${ }^{141}$ Ibidem, pg. 120. 
Para os construtivistas, a etnicidade deve ser entendida como uma comunidade imaginada que se distingue não pelas suas falsidades/autenticidades, mas pelo estilo em como são imaginadas. A etnicidade é uma construção social de expedientes complexos, que através de múltiplos mecanismos, uma vez germinada a consciência, se desenvolve através de progressivas redefinições que ocorrem a todos os níveis do Estado e da sociedade". ${ }^{142}$

$\mathrm{Na}$ leitura realizada pelo construtivismo, a etnicidade seria, portanto, um atributo social (e não individual), que erigiria estruturas de cognição e valores, influenciando o comportamento dos indivíduos na sociedade ${ }^{143}$. Embora não sejam, assim, essencialmente conflituosas, tais concepções valorativas poderiam levar ao conflito.

BRANCO (2006, pg. 13) ressalta, sem embargo, que em alguns pontos os construtivistas se colocariam em uma posição intermediária entre instrumentalistas e primordialistas $^{144}$. Por mais que sejam os indivíduos maximizadores, encontrariam limitações em aspectos fixos da etnicidade.

Se de um lado o primordialismo não conseguiria, por exemplo, na visão de seus sucessores, distinguir identidade cultural e identidade cultural politicamente relevante, de outro, indagavam seus defensores, "Qué les pasaría a nuestros modelos sobre etnicidade si la misma gente que estudiamos se describen a ellos mismos en términos primordialistas? Estamos obviando algo dentro de nuestros modelos? ${ }^{145 "}$, Ou como indagava o próprio ANDERSON (2008, pg. 200)²14, "por qué lós indivíduos están dispuestos a morir por estas invenciones?”. NASCIMENTO (2001, pg. 39) também assim refletia acerca do problema:

“Apesar da hegemonia na comunidade intelectual, a escola moderna/construtivista permanece fustigada pelo espectro do primordialismo. Se as nações são uma invenção moderna, por que são percebidas popularmente como eternas e primordiais? Como

\footnotetext{
${ }^{142}$ BRANCO, Carlos Manuel Martins. Etnicidade e Violencia Etnica. Revista Militar, novembro de 2006, pg. 13.

${ }^{143}$ Nas palavras de HERRARTE, "dentro del constructivismo, el grupo étnico es cambiable, sujeto a negociación para llegar a su final definición, y, fundamentalmente, el grupo étnico es definido según el contexto". HERRARTE, Gustavo. Identidade Étnica. Grupos étnicos y otros mitos sobre la etnicidade: interaccióon, cognición y una visión de etnicidad sin grupos étnicos. Revista de la Universidad del Valle de Guatemala. N. 16. 2006. Pg. 119.

${ }^{144}$ Conforme opina, “a verdade é que as abordagens estudadas nao só se complementam, como nalguns aspectos se reforçam mutuamente, nao detendo nenhuma delas o monopólio explicativo. Em última análise nenhuma é suficientemente abrangente para explicar todos os fenômenos. O que explicam umas teorias nao explicam as outras; umas explicam melhor certas situações do que outras". BRANCO, Carlos Manuel Martins. Etnicidade e Violencia Etnica. Revista Militar, novembro de 2006, pg. 13.

145 Geertz, Clifford. Primordial Loyalties and Standing Entities: Anthropological Reflections on the Politics of Identity. Public Lectures, No. 17.
}

146 ANDERSON, Benedict: Comunidades Imaginadas. São Paulo. Cia das Letras, 2008, pg. 200. 
explicar o ressurgimento de movimentos políticos e culturais de cunho étnico e nacional, aparentemente há muito esmagados pelo rolo compressor das políticas nacionais homogeneizantes? Por que a cultura e a psicologia coletiva das comunidades nacionais são invariavelmente compostas de elementos pré-modernos? Essas questões remetem à tradição primordialista, que, apesar de muito desdenhada como irracional ou 'falsa consciência', tem mantido certo fôlego graças ao trabalho de resgate efetuado por alguns autores". 147

Em uma leitura conciliatória, notava CHANDRA (2012, pg. 09) que a crença nas características da etnicidade como primordiais por si só geravam efeitos sobre as mesmas, assim descrevendo tal processo:

Quando indivíduos se comportam como se suas identidades étnicas fossem primordiais, isto produz padrões diferentes de comportamento daqueles quando creem que estas categorias são construídas? Paradoxalmente, então, se adotarmos as premissas construtivistas, devemos levar a sério, pela primeira vez, as raízes primordiais. ${ }^{148}$

Em razão das pontuais aproximações entre primordialistas e construtivistas, autores outros proporiam perspectivas sincréticas dos fenômenos étnicos.

Apesar dos questionamentos, as conclusões dos circuncialista seriam demonstradas pelo crescimento de populações autóctones americanas, muçulmanas na Bósnia, por exemplo, em percentuais muito acima do restante da população. Ou, em outro exemplo, da mudança na autorrepresentação de grupos, como em Porto Rico, onde nos últimos cinquenta anos a maioria da população deixaria de se classificar como "negra", para "mulata", e em seguida "branca"; ou no Brasil, onde a maior parte da população deixou nos últimos anos de se reconhecer como "branca" ou "negra" para entender-se "parda", casos estes que não se explicavam pelo aumento na taxa de natalidade ou migrações, senão pela adaptação na autoidentificação de indivíduos em outros grupos. $^{149}$

Em outros casos, grupos inteiros viriam a desaparecer pela mera modificação da autopercepção, no que viria a chamar de "genocídio por redefinição"; enquanto novas categorias surgiriam, em fenômeno conhecido como "etnogênese".

147 NASCIMENTO, Paulo César "Dilemas do nacionalismo" Revista Brasileira de Informação Bibliográfica em Ciências Sociais (BIB) 56. São Paulo: ANPOCS, 2003. Pg. 38.

${ }^{148}$ CHANDRA, Kanchan. Constructivist Theories of Ethnic Politics. 2012. Pg. 09. Disponível em: http://politics.as.nyu.edu/docs/IO/2587/Chapter1-Introduction-09-28-10.pdf. (Consulta realizada em 20/11/2015)

${ }^{149}$ Ibidem, pg. 4. 
O construtivismo explicaria tais episódios a partir de fatos políticos e econômicos, como eleições, partidos, ciclos de competição política, industrialização, urbanização, entre outros, repercutindo nas divisões étnicas. Modificavam-se, desta forma, as bases conhecidas das relações entre etnicidade, política e economia, gerando uma gama de novas explicações para estes componentes.

No atual estágio, CHANDRA (2012, pg. 2) teceu a seguinte síntese, acerca do panorama geral das vertentes acima apresentadas:

Embora as teorias sobre a formação de grupos étnicos tenham sido conduzidas pelos pressupostos construtivistas de que as identidades étnicas podem mudar ao longo do tempo, as teorias dos efeitos da etnicidade sobre os resultados econômicos e políticos são conduzidas, principalmente, pelos pressupostos primordialistas de que estas identidades são fixas. ${ }^{150}$

As teorias abordadas repercutiriam na forma como as questões étnicas seriam explicadas, seus agrupamentos, reivindicações e sobretudo conflitos. No Brasil tais correntes vêm sendo utilizadas não só como tentativa de compreender suas questões étnicas, como também como insumo para a atuação do Estado na adoção de suas políticas, conforme dedicado no capítulo seguinte.

${ }^{150}$ Ibidem, pg. 2. 


\title{
Cap. 3.2. A evolução do conceito de etnia no Brasil e o tratamento da questão étnica pelo Estado Brasileiro
}

Nas palavras de RIBEIRO (1972, pg. 3),

\begin{abstract}
"O Brasil não nasceu como etnia e se estruturou como nação em consequência de um desígno de seus criadores. Surgiu, ao contrário, como uma espécie de subproduto indesejado de um empreendimento colonial, resultante da Revolução mercantil, cujo propósito era produzir açúcar, ouro ou café e, sobretudo, gerar lucros exportáveis. Desse empreendimento resultou ocasionalmente um povo e mais tarde, uma nação."
\end{abstract}

Até recentes anos, as temáticas ligadas à etnicidade no país mantinham foco, exclusivamente, nas questões indígenas.

O pensamento brasileiro acerca dos grupos éticos pode ser classificado, em sua evolução constante, em pelo menos três fases suficientemente distintas. Na primeira, rotulada "racismo brasileiro", sobressaiu a chamada teoria da fusão das raças, encontrando Gilberto Freyre e Arthur Ramos como mais célebres representantes. Em seguida, ganharia corpo a teoria da aculturação, de Eduardo Galvão, dando lugar, na sequência à noção de transfiguração étnica de Darcy Ribeiro. Em um terceiro momento, sobrelevou-se a teoria da fricção interétnica, de Roberto Cardoso de Oliveira. Cada uma delas corresponde, respectivamente, às ideias de 1) mestiçagem 2) aculturação; 3) integração $^{152}$.

No campo propriamente da Antropologia, pode a evolução metodológica da etnografia, até 1955, ser classificada da seguinte forma: a) Sec. XVI-XVIII, fase précientífica, com contribuição de cronistas; b) Sec. XIX, até 1910, pesquisas científicas e expedições; c) estudos sobre as culturas indígenas e afro-brasileira ${ }^{153}$.

A busca por uma identidade nacional, que inicia-se com o grito de independência em 1822, ganha espaço nas artes, em especial na literatura, invocando-se a imagem do índio como parte do povo brasileiro. Durante o romantismo o índio era visto sob o ideal do bom selvagem, como figura ingênua, forte, valorosa. No mesmo

\footnotetext{
${ }^{151}$ RIBEIRO, Darcy. Teoria do Brasil. Rio de Janeiro: Paz e Terra, 1972, pg. 3.

152 ATHIAS, Renato. A noção de identidade étnica na antropologia brasileira. De Roquette Pinto a Roberto Cardoso de Oliveira. Editora Universitária UFPE. Recife, PE. 2007. Pg,51,

${ }^{153}$ Ibidem, pg, 50,
} 
período, correntes deterministas vão enfatizar o papel do clima, da raça e da pureza como justificadores da superioridade branca-europeia. A ideia é disseminada no Brasil por meio das teses do "branqueamento" 154 , que se desenvolveram no período.

Outras teorias reagiriam contra aquela tendência de pensamento, tendo-se como ponto culminante desta reação o advento da Semana de Arte Moderna, de 1922, que marcaria o início do modernismo brasileiro, representando uma ruptura com tradições intelectuais, propondo-se "novas concepções orientadas para tudo o que pudesse ser identificado como puramente nacional" $" 155$. No centro desta busca encontrava-se o índio, como figura genuinamente brasileira. Apesar dos esforços e da postura crítica, contudo, muitos dos antigos clichês sobreviveriam à onda inovadora.

O chamado "racismo à brasileira" surgiria como fruto da ainda incipiente noção dos agrupamentos humanos como subespécies, limitada, sobretudo, ao aspecto racial, aí confluindo teorias salvacionistas, racistas, que viam o índio como improdutivo, atrasado.

O racismo brasileiro proclama de maneira paradoxal — como o mostra Freyre - uma unificação harmoniosa em termos biológicos das três matrizes étnicas que constituem a sociedade (ela própria fortemente hierárquica), unificação que se exprimiria na "cordialidade" brasileira ou nos costumes tais quais os ritos afro-brasileiros expressos no carnaval ${ }^{156}$.

Já na segunda etapa, surge a ideia de aculturação, e, a partir de críticas a ela, a teoria da Transfiguração Étinica, de Darcy Ribeiro.

Segundo GALVÃO (1979, pg. 129), a aculturação seria um fenômeno que,

aparece quando grupos de indivíduos de culturas diferentes entram em contato direto e permanente, com suas conseqüências sobre as normas culturais destes grupos. Distingue aculturação e mudança cultural que é um aspecto do mesmo processo, e assimilação que é uma fase do processo de aculturação ${ }^{157}$.

Sob influência de tal concepção, têm-se no retrospecto institucional no país a criação, em 1910, do Serviço de Proteção aos Índios-SPI, sucedido em 1967 pela

\footnotetext{
154 ATHIAS, Renato. A noção de identidade étnica na antropologia brasileira. De Roquette Pinto a Roberto Cardoso de Oliveira. Editora Universitária UFPE. Recife, PE. 2007. Pg,44

${ }^{155}$ Ibidem, pg. 45.

${ }^{156}$ Ibidem, pg. 68.

${ }^{157}$ GALVÃO, E. Índios e Brancos no Brasil, encontro de sociedades. Rio de Janeiro: Paz e Terra, 1979. Pg. 129, apud ATHIAS, Renato. A noção de identidade étnica na antropologia brasileira. De Roquette Pinto a Roberto Cardoso de Oliveira. Editora Universitária UFPE. Recife, PE. 2007. Pg. 90.
} 
Fundação Nacional do Índio-Funai. ATHIAS (2007, pg. 15) recorda que sob a égide da primeira entidade, "o índio sempre foi considerado uma categoria genérica devendo ser integrado à sociedade nacional. (...). Esta política indigenista na sua prática confirma a "redução" das etnias indígenas a uma só categoria abstrata chamada: índio, inventada pelo 'civilizado' outra categoria abstrata". ${ }^{158}$

Já a terceira corrente faz crítica ao conceito de aculturação e à transfiguração étnica, pela baixa operacionalidade destas, substituindo-as pela ideia de fricção étnica, com ênfase na identidade contrastiva, desenvolvida por OLIVEIRA, (1976 pg. 36) pressupondo que a identidade social estaria baseada em relações sociais, sob códigos que as orientam:

"Um indivíduo ou grupo indígena afirma a sua etnia contrastando-se com uma etnia de referência, tenha ela um caráter tribal (por exemplo, Terêna, Tikúna, et.) ou nacional (por exemplo, brasileiro, paraguaio, etc.). O certo é que um membro de um grupo indígena não tem sua pertinência tribal a não ser quando posto em confronto com membros de outra etnia. Em isolamento, o grupo tribal não tem necessidade de qualquer designação específica ${ }^{159}$

É o sentido que afirmava também BOURDIEU (1984, pg. 479), para quem, “a identidade social reside na diferença, e a diferença é afirmada por oposição aquilo que está mais próximo, que representa a maior ameaça". ${ }^{160}$

A noção de fricção interétnica, que reconhece a dimensão do conflito e da interação continuada na dinâmica identitária, sustentaria a admissão pela Funai de processos de reconformação e reemergência de identidades nos anos recentes, orientando a atuação da Funai na delimitação de novas Terras Indígenas com aquelas características. A concepção adotada era a assim descrita por VERAS \& DE BRITO (2012, pg. 115):

"Tomando conhecimento de direitos garantidos pelo Estado, grupos são levados a
situacionalmente reorganizar seus símbolos culturais, lançando mão de sua identidade
étnica e reivindicar seus direitos. Sem contar com evidências empíricas da natureza de
sua distintividade, Oliveira (1999) afirma que 'a única continuidade que talvez seja
possível sustentar é aquela de, recuperando o processo histórico vivido por este grupo,

158 ATHIAS, Renato. A noção de identidade étnica na antropologia brasileira. De Roquette Pinto a Roberto Cardoso de Oliveira. Editora Universitária UFPE. Recife, PE. 2007. Pg 15.

${ }^{159}$ CARDOSO DE OLIVEIRA, Roberto. Identidade, Etnia e Estrutura Social. São Pualo: Pioneira, 1976.

160 
mostrar como ele refabricou constantemente sua unidade e diferença frente a outros com os quais esteve em interação",161.

Segundo os autores desta fase, "a emergência étnica tem uma relação direta com a política estatal, pois as políticas públicas são fomentadas por necessidades. Os grupos não surgem necessariamente com as políticas, mas são restituídos em seus territórios tradicionais, onde podem reorganizar suas coletividades com a ajuda do Estado." 162

Os pensadores desta terceira fase, conforme explica ATHIAS (2007),

partem da proposição inovativa de Fredrik Barth (1969) de considerar a noção de grupo étnico como um "tipo organizacional". Para estes antropólogos, a identidade étnica é o que vai ser determinante para o desenvolvimento do grupo, do ponto de vista organizacional e ideológico, identificando-se com uma identidade, e que se preserva enquanto grupo étnico desde que sejam visíveis as condições organizacionais coletivas. $^{163}$

A partir daí, importantes contribuições seriam dadas no âmbito da antropologia brasileira, como aquelas repersentadas pelos trabalhos de João Pacheco de Oliveira Filho, em especial tratando das "relações intersocietárias".

A noção de integração, ao contrário do que preconizava a de aculturação, proporia que os povos indígenas se integrassem à sociedade sem perder seus traços culturais, decidindo, assim, os rumos de seu desenvolvimento.

O pluralismo foi finalmente absorvido pelo Constituinte de 1988, consagrando no texto da Carta Magna regras e princípios no sentido preconizado por estas últimas correntes. Cita-se, por exemplo, na Seção que trata Da Cultura, a determinação de que “O Estado protegerá as manifestações das culturas populares, indígenas e afrobrasileiras, e das de outros grupos participantes do processo civilizatório nacional". A atual Constituição seria responsável, ainda, pelo fim do "poder tutelar" do Estado sobre os índios, avanços estes que devem sua implementação à evolução teórica acima apontada.

\footnotetext{
${ }^{161}$ VERAS, Marcos Flávio Portela \& DE BRITO, Vanderli Guimarães. "Identidade Étnica: A dimensão política de um processo de reconhecimento. ANTROPOS Revista de Antropologia, Ano 4, Volume 5, maio de 2012. Pg. 115.

${ }^{162}$ VERAS, Marcos Flávio Portela \& DE BRITO, Vanderli Guimarães. "Identidade Étnica: A dimensão política de um processo de reconhecimento. ANTROPOS Revista de Antropologia, Ano 4, Volume 5, maio de 2012. Pg. 121.

163 ATHIAS, Renato. A noção de identidade étnica na antropologia brasileira. De Roquette Pinto a Roberto Cardoso de Oliveira. Editora Universitária UFPE. Recife, PE. 2007. Pg 53.
} 


\section{Cap. 4. Mobilidade Identitária}

"a gente não virou índio, porque a gente já era índio, só
tiramos da gaveta isso que a gente escondia”.

Apresentadas acima as teorias que no decorrer da evolução dos estudos sobre identidades buscaram explicar os contornos da etnicidade, e admitindo-se, conforme defendem as correntes circunstancialistas, a fluidez das fronteiras étnicas, importa investigar como se dá tal processo de mudanças na autopercepção coletiva, debatendose, ainda, sobre quais condições as propiciariam, sobretudo indagando-se qual o papel do Estado - e das políticas públicas - em tais movimentos.

Nas palavras de MONTES (1996, pg. 1):

“é impossível pensar a identidade como coisa, como permanência estática de algo que é sempre igual a si mesmo, seja nos indivíduos, seja nas sociedades e nas culturas. Ao contrário, é preciso pensar que, uma vez que as sociedades são dinâmicas e a vida social não está parada, também a identidade não é uma coisa fixa, mas algo que resulta de um processo e de uma construção. E não podemos entender essa construção sem o contexto onde ela se dá"165.

$\mathrm{Na}$ esteira das bases fundadas especialmente pelo construtivismo, a ideia de "mudança" ou "transformação" de identidades passou a ser melhor compreendida, para tanto auxiliando as recentes teorias que aportaram as noções de identidade étnica nominal e identidade étnica ativada, que aqui apresentamos.

De acordo com esta categorização, identidade étnica nominal seria aquela em que características individuais tornariam o sujeito apto a ser membro de um grupo. Já as identidades étnicas ativadas seriam aquelas identificadas por terceiros para atribuir um sujeito como membro da coletividade, a partir das características que externa. Segundo

${ }^{164}$ Frase de Moradores da Comunidade Takuara, no interior da Floresta Nacional do Tapajós. In VAZ FILHO. As Comunidades Munduruku na Flona do Tapajós. in RICARDO, Fany (org.). Terras Indígenas \& Unidades de Conservação da natureza: o desafio das sobreposições. São Paulo: Instituto Socioambiental. 2004. Pg. 572.

165 MONTES, Maria Lúcia. Raça e Identidade: entre o espelho, a invenção e a ideologia. In: SCHWARCZ, L. M. \& QUEIROZ, Renato Silva (orgs.) Raça e Diversidade. São Puao: EDUSP, 1996, pg. 1. 
este esquema, todo e qualquer indivíduo possuiria um repertório de características que poderiam ser "ativadas" para então serem considerados membros de um grupo em específico. $^{166}$

A identidade prática seria, destarte, conformada de acordo com a situação vivida pelo grupo, moldável segundo a circunstância experimentada em um dado momento e limitada pelas fronteiras representadas pela identidade étnica nominal. Desta forma é que indígenas negariam sua condição de silvícola em ambientes urbanos, extrativistas comportar-se-iam como populações tradicionais diante da possibilidade de serem beneficiados com a criação de uma reserva, entre outros exemplos, assim explicados por BRANDÃO (pg. 66.):

"na maioria das situações resulta vantajoso para atores (sociais, étnicos) mudarem a sua etiqueta étnica com o objetivo de evitarem o ônus do fracasso; assim, pois, onde existe uma identidade alternativa ao alcance, o resultado consistirá em um trânsito pessoal de uma identidade para a outra, ainda que não se efetue nenhuma alteração nas características tradicionais do status $^{167}$.

Coerentemente com esta linha de raciocício, assim formulava o autor ao tratar da conflituosidade entre dois grupos indígenas, os Xerentes e Khrahôs, referindo-se à substância da etnicidade:

Qual é o momento em que um xerente se reconhece xerente por oposição ao krahô com que se encontra? Quando emerge para krahôs e xerentes a necessidade de se reconhecerem índios, diante do branco que lhes cerca o território e a vida por todos os lados? Qual é a substância da etnicidade: a natureza? a cultura? a organização social própria de um modo de vida original e, com freqüência, minoritário?

Uma maneira de colocar a questão é indagar-se sobre a substância da etnicidade. Substância que já foi pensada em termos biológicos, quando se falava de raças e de sua heterogeneidade. A noção de cultura veio substituir-se à de raça, dentro de um movimento que se quis generoso, e certamente o foi. E já que a cultura era adquirida, inculcada e não biologicamente dada, também podia ser perdida. Inventou-se o conceito de aculturação e com ele foi possível pensar - para gáudio de alguns, como os engenheiros sociais, e para pesar de outros, como os antropólogos - na perda da diversidade cultural e em cadinhos de raças e culturas.

Não se trata só do Brasil, é claro. Este foi um problema de quantos países se viram diante da tarefa de constituir uma nacionalidade. Na África das lutas de independência e pós-colonial, a etnicidade era vista como um empecilho à constituição de uma nação moderna, e acusava-se o chamado 'tribalismo' de dificultar sua construção. Este

166 CHANDRA, Kanchan. Constructivist Theories of Ethnic Politics. 2012. Pg. 06. Disponível em: http://politics.as.nyu.edu/docs/IO/2587/Chapter1-Introduction-09-28-10.pdf. (Consulta realizada em 20/11/2015)

${ }^{167}$ BRANDÃO, CR. Identidade e Etnia. S. Paulo, Ed. Brasiliense, 1986. Pg. 66. 
argumento ainda é contradiço e supõe uma ligeira arraigada de cada homem com a cultura materna." 168

O mesmo estudioso, focado no contato interétnico dos índios Terena, Krahô, Assurini, Gaviões e Tukuna com povos extrativistas enfocou a mudança cultural sofrida por aqueles, sem que, contudo, perdessem o sentimento de "permanecer índio", referindo-se às ideias que os índios possuem sobre o mundo e suas representações sociais, sugerindo que o sentimento indígena poderia ser reativado em momentos posteriores.

Assim é que se pode melhor compreender a epígrafe deste capítulo, que denota a postura dos índios Takuna de "ativar" seus atributos indígenas, fazendo emergir a identidade que se encontrava silenciada.

Neste fluxo, a ativação dos atributos da identidade étnica impulsionaria um processo de mudança, no longo prazo, do próprio repertório de atributos do indivíduo, modificando, destarte, os limites do conjunto de características étnicas, ou, a identidade étnica nominal. A partir daí, autores como CHANDRA (2012, pg. 16) ${ }^{169}$ diferenciam a "estrutura étnica" da "prática étnica", a primeira associada ao repertório, e a segunda à identidade ativada.

Enquanto a estrutura tende a se manter fixa no curto prazo, podendo variar no longo, a prática pode modificar-se no curto prazo, consistindo nos constrangimentos impostos pelos limites do repertório, verdadeiramente o que se intitula fronteiras étnicas.

A incessante busca pela autêntica identidade de um grupo, ou da substância étnica tem, sob a visão aqui exposta, sua importância mitigada, considerando que a identidade prática é construída a partir de um conjunto mais amplo de atributos.

Neste ponto, retomamos a parte final do capítulo 3.1 onde, após apresentar as correntes de pensamento acerca da etnicidade ressaltou-se a utilidade de algumas noções primordialistas, para aqui acentuar que os atributos somáticos teriam neste esquema relevância maior, consistindo nas mais importantes estruturas de

\footnotetext{
${ }^{168}$ Ibidem, pg. 33.

169 CHANDRA, Kanchan. Constructivist Theories of Ethnic Politics. 2012. Pg. 16. Disponível em: http://politics.as.nyu.edu/docs/IO/2587/Chapter1-Introduction-09-28-10.pdf. (Consulta realizada em 20/11/2015).
} 
constrangimento para as identidades grupais, ou os mais atrativos elementos daquele repertório. A par destas, teriam importância características históricas, institucionais, econômicas, ideológicas, normas sociais, fatores territoriais, etc., justamente como sugeria ANDERSON (2008) ${ }^{170}$ ao enfatizar, por exemplo, a importância da língua na formação das identidades.

Paralelamente, autoras como PHILLIPS (2007, pg. 150) aportariam a ideia de preferências "aprendidas", ou "adaptativas"171, destacando que, ao contrário de préexistentes, ou dadas, as preferências seriam construídas tendo em conta o contexto social, assim esclarecendo BIROLI (2013, pg. 82)

\begin{abstract}
“as preferências são sempre aprendidas porque as considera à luz de outra noção, a de preferências 'próprias'. Em outras palavras, e sem avançar de maneira precisa nessa discussão neste momento, estaríamos trabalhando com uma oposição entre agência individual e estruturas (valores, constrangimentos, instituições) sociais" ${ }^{172}$.
\end{abstract}

Desta maneira, entender que as identidades dos indivíduos são "socialmente apreendidas" não significaria dizer não serem capazes de fazer escolhas, e sim que as escolhas são realizadas sob influência, constrições e pressões do meio social, ainda que de modo imperceptível.

Admitindo-se, portanto, a noção de que as preferências levariam em conta projeções feitas pelos indivíduos, segundo posições ocupadas na sociedade, emerge a problemática referente às preferências formadas por grupos em condição de subalternidade, uma vez que as preferências externadas absorverão as próprias desigualdades sociais do meio, reproduzindo os padrões de opressão ali presentes.

A perspectiva vai ao encontro da noção trabalhada por MERLEAU-PONTY de "corpo vivido" - bastante utilizada por correntes feministas -, significando "a experiência, a percepção, a motricidade, retomada como base para a compreensão da inscrição corporal do conhecimento nas teorias sobre aprendizagem" ${ }^{\text {"173 }}$. A ideia de corpo vivido prestigiaria a posição individual dos membros das coletividades, tendo relevo a miríade de relações que cada pessoa em particular experimentaria, gerando

\footnotetext{
${ }^{170}$ ANDERSON, Benedict: Comunidades Imaginadas. São Paulo. Cia das Letras, 2008.

${ }^{171}$ PHILLIPS, Anne. Multiculturalism without Culture. Princeton: Princeton University Press, 2007.

${ }^{172}$ BIROLI, Flávia. Autonomia, opressão e identidades: a ressignificação da experiência na teoria política feminista. Revista Estudos Feministas, vol. 21, numero 1, 2013. UFSC. Pg. 82.

${ }^{173}$ NÓBREGA. Terezinha Petrucia. "Corpo, percepção e conhecimento em Merleau-Pontu. Estudos de Psicologia, 2008. UFRN.
} 
semelhanças com o restante da coletividade. Ou, ainda com apoio em BIROLI (2013, pg. 88),

O conceito de "corpo vivido" permitiria pensar a noção de identidade como correspondente a vivências concretas. Seu mérito seria, nessa abordagem, destacar a identidade como um conjunto de variáveis ou parcelas sobrepostas, mas distintas, da experiência. Em outras palavras, o conceito permitira dar conta da singularidade que constitui as identidades individuais ou subjetivas, sem ignorar que elas se definem apenas em interações sociais concretas e são por elas constituídas. ${ }^{174}$

Com base nestas premissas, que somadas sustentam que os indivíduos - e as coletividades - teriam ao seu dispor um repertório de atributos para construir suas identidades, é que estudiosos apontariam a carência de recursos e a via do autorreconhecimento como indígenas para supri-las como explicação para os fenômenos ora objeto de estudo. É o que afirmava, por exemplo, RICARDO, (2004, pg. 9):

A institucionalização da indianidade, portanto, pode vir a ser uma necessidade na medida em que essas comunidades só têm acesso aos direitos de bem-estar social via a exacerbação dos particularismos.

O fato é que nesse universo de fronteiras móveis e redes cada vez mais densas, heterogêneas e assimétricas de informações, valores e práticas, é imperioso atentar para os mecanismos de proteção da diferença cultural, sem contudo incorrer na folclorização das minorias étnicas, tomando suas culturas como totalidades fechadas e impermeáveis à história. Essa concepção museológica de cultura já não se sustenta no mundo de hoje, tampouco a crença no modelo ocidental como destino inexorável de todas as sociedades. ${ }^{175}$

Tal visão presta-se a mitigar as constantes suspeitas que pairam sobre as transformações identitárias experimentadas pelos grupos, demonstrando a naturalidade de tal processo.

Sempre que processos como os de identificação étnica são discutidos, idéias como as de estratégia, jogo e contraste, por exemplo, entram em cena. Em conjunto elas revelam a qualidade política das relações envolvidas em tais processos, qualidade que, afirmada, não deve ser também exagerada. Estabelecer como identidade uma etnia significa demarcar territórios simbólicos. Significa construir os sinais diacríticos que sobreponham àquilo com que se vive e pensa - os rituais da religião, os costumes do sexo, as regras de nominação, etc. - a marca da diferença. Povos ou frações de povos, como "os brasileiros da fronteira com o Paraguai" e "os terena do sul do Mato Grosso do Sul", não possuem, como uma essência a tudo antecedente, uma identidade. Como cultura, ela não existe sob a forma de um repertório dado, estável e facilmente reconhecível, de sentimentos e idéias, regras e ornamentos do corpo. Mas onde quer que situações concretas o exijam, ela, identidade étnica, é construída.

$(\ldots)$

\footnotetext{
${ }^{174}$ BIROLI, Flávia. Autonomia, opressão e identidades: a ressignificação da experiência na teoria política feminista. Revista Estudos Feministas, vol. 21, numero 1, 2013. UFSC. Pg. 88.

175 RICARDO, Fany (org.). Terras Indígenas \& Unidades de Conservação da natureza: o desafio das sobreposições. São Paulo: Instituto Socioambiental. 2004. Pg. 9.
} 
"Crise de identidade", "confusão de identidade", "manipulação de identidade", "identidade negativa" são os nomes que alguns estudiosos do assunto usam para traduzir os descaminhos do processo de identificação. Descaminhos que podem acontecer de diversos modos, em várias dimensões. Podem ocorrer com alguém em seu meio cotidiano, quando entre ela e as pessoas que desde a infância lhe são afetivamente importantes - porque delas lhe vêm amor, segurança e inculcação de habitus - surgem bloqueios, trocas de sentimentos e significados inadequadas, conflitivas. Podem acontecer com uma categoria de sujeitos quando entre eles, coletivamente, e outras categorias de pessoas ou instituições de seu mundo social há conflitos e inadequações, e suas conseqüências extrapolam as dimensões da família nuclear e chegam às da classe social, do grupo religioso, da minoria nacional migrante, da tribo de índios no seu todo. Podem ocorrer, em escala ainda mais ampla, quando dois mundos sociais entram em contato e as relações políticas, econômicas e culturais entre eles são desiguais e tanto a vida quanto a identidade do grupo dominado ou colonizado precisam submeter-se ao controle dos símbolos impostos de vida e identidade do dominador ou do colonizador. 176

Naturalmente, a possibilidade de se adaptar os padrões identitários mostra-se desigual entre os grupos sociais. Há sempre, entretanto, uma tendência à tentativa de se afastar os aspectos desvantajosos dos esteriótipos criados pelo outro, aproveitando das características mais bem aceitas, o que, com o tempo, cria uma percepção de que tais são as características que melhor identificam o grupo.

A hipótese de transformações na autopercepção dos grupos étnicos em situações de carência, observada em diversos episódios por todo o mundo, daria corpo à hoje sólida literatura que construiu a intitulada relative deprivation theory - teoria da privação relativa, melhor pormenorizada no capítulo seguinte, de grande utilidade para a explicação dos fenômenos ora enfocados. Neste sentido é que a identidade seria fruto das condições impostas pelo meio

${ }^{176}$ BRANDÃO, CR. Identidade e Etnia. S. Paulo, Ed. Brasiliense, 1986. Pg. 66. 


\title{
Cap. 4.1. A Teoria da Privação Relativa (Relative Deprivation Theory)
}

\begin{abstract}
"É que antes a gente não tinha nenhuma ajuda para os índios. O índio era excluído, índio era pior. Quando eles vê que os índios tiveram condições, quando a FUNAI e a FUNASA tiveram condições de ajudar na saúde, em outros materiais, aí acharam que era melhor se identificar. Então foi isso que aconteceu. Aí todo mundo já quer ser índio. Por causa disso, que na saúde nas comunidades tem rádio, medicamento, pessoal de enfermagem, e foi isso que chamou o pessoal todo pra vir se identificar". ${ }^{177}$
\end{abstract}

As manifestações étnicas ao redor do mundo caracterizam-se, a toda evidência, pela heterogeneidade. Em alguns casos grupos minoritários apresentam-se como populações carentes, enquanto em outros vivenciam condições privilegiadas. Em certos exemplos fundam-se as agremiações em aspectos religiosos, em outros raciais, eventualmente em razão de origem; por vezes surgem a partir de estímulos oriundos do processo de colonização, em outros casos com fundamento em raízes imemoriais. Desta miríade de situações diversificadas emerge a dificuldade de se inferir explicações padronizadas para todos eles.

Exemplificativamente, enquanto teorias explicam a diferenciação étnica com fundamento no isolamento, outras, como a da fricção étnica, sustentam-se sobre o contato entre grupos distintos.

Em meio à pluralidade, sobrelevaram correntes que identificavam o papel de variáveis políticas e econômicas na equação das mudanças identitárias.

MARX \& ENGELS $(1977)^{178}$, por exemplo, trataram da distribuição desigual de poder como fonte de conflitos e motor de mudanças sociais. A etnicidade seria, da mesma forma, parte desta dinâmica, sendo a construção do "outro" feita por aquele que se apresenta em condição privilegiada de poder.

\footnotetext{
${ }^{177}$ Frase de André Cruz, maio/2010, in SOUZA, Marina Oliveira e Souza. Passar para Indígena - na Reserva de Desenvolvimento Sustentável Amanã (AM). Dissertação de mestrado. UFMG. Belo Horizonte. 2011. Pg. 86

${ }^{178}$ MARX, Karl e ENGELS, Friedrich (1977), Collected Works, London, Laurence and Wishart.
} 
Os teóricos enxergariam um sistema social composto por dois subsistemas, uma estrutura, e envolta a ela uma super-estrutura. A estrutura econômica teria neste esquema primazia sobre a super-estrutura cultural, à qual pertenceria a etnicidade ${ }^{179}$. Analisando a questão judaica, apresentariam perspectiva de que os conflitos étnicos seriam, em realidade, "sintomas de uma estrutura capitalista que cria condições para que os indivíduos permaneçam alienados uns dos outros" $" 180$. Assim é que para os autores a etnicidade não seria causa, senão consequência das desigualdades promovidas pelo capitalismo. Ao mesmo tempo, a etnicidade seria uma construção burguesa para se desviar a atenção da classe trabalhadora quanto à exploração econômica e política promovida pelo sistema capitalista.

Sob este influxo, as correntes que teriam como base o marxismo edificariam sobre a relação entre a etnicidade e as desigualdades de classes suas explicações sobre os fenômenos étnicos.

Embora esta visão tenha sido objeto de críticas, e colocada à prova por inúmeros casos concretos experimentados pelo mundo - especialmente na União Soviética, onde a questão étnica avultou-se, a despeito da supressão das classes econômicas -, tal abordagem prestou contribuição ao forçar a incorporação de variáveis políticoeconômicas sobre o estudo da etnicidade.

No século XIX, BOURDIEU (1997, pg. 16), já citado alhures, exploraria, dentro daquela perspectiva, a ideia de habitus e campo na explicação dos fenômenos sociais, especialmente apresentando como o capital cultural reproduziria as estruturas existentes do capital econômico, cultural, social e simbólico. Para o autor, os indivíduos internalizariam uma série de estruturas por meio das quais percebe, compreende e avalia

\footnotetext{
${ }^{179}$ MARX e ENGELS aput GÓIS, Pedro Manuel Rodrigues da Silva Madeira e. A construção secular de uma identidade étnica transnacional: a cabo-verdianidade. Tese de doutoramento. Universidade de

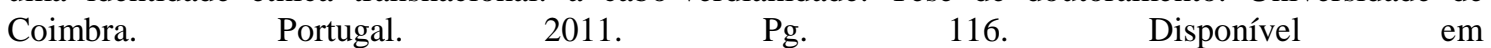
https://estudogeral.sib.uc.pt/bitstream/10316/17848/1/tese\%20versão\%20final.pdf. (Consulta realizada em 19/11/2015.)

180 GÓIS, Pedro Manuel Rodrigues da Silva Madeira e. A construção secular de uma identidade étnica transnacional: a cabo-verdianidade. Tese de doutoramento. Universidade de Coimbra. Portugal. 2011. Pg. 116. Disponível em https://estudogeral.sib.uc.pt/bitstream/10316/17848/1/tese\%20versão\%20final.pdf. (Consulta realizada em 19/11/2015.)
} 
o mundo. Esta estrutura interna, que o autor entenderia como habitus refletiria as divisões objetivas da sociedade ${ }^{181}$.

O campo, por sua vez, seria um espaço de competição, onde os atores degladiariam pelos diversos tipos de capital: político, econômico, cultural, social e simbólico. $^{182}$

O habitus seria, assim, o "princípio organizador das práticas sociais", enquanto a sociedade seria um emaranhado de campos em interseções. Aquele, por sua vez, modificar-se-ia quando a estrutura histórica do campo também se modificasse. ${ }^{183}$

As contribuições de BOURDIEU (1997) serviriam para a formulação de uma nova forma de se conceber a etnicidade, assim sintetizada:

De acordo com Sinisa Malesevic (2004) em Bourdieu devemos entender a "etnicidade" como uma categoria de prática que emerge e se mantém na acção e interacção social: os indivíduos tornam-se agentes sociais, ou seja membros do grupo, através da acção social, da participação em determinadas práticas colectivas. Um grupo étnico torna-se um grupo através do processo dinâmico de participação activa entre os seus membros. Os indivíduos não agem necessariamente como criaturas racionais ou utilitárias - são muitas vezes guiados por crenças, hábitos, tradições e por ai fora - mas em última análise a formação de grupos e a acção colectiva depende da acção individual. ${ }^{184}$

Com fulcro nestes avanços, gestou-se no século anterior teoria que exporia os efeitos da submissão de grupos étnicos a posição de relativa carência, o que ressaltaria aspectos de sua identidade particular, ou, para utilizar os termos acima apresentados, levaria à ativação de sua identidade étnica, à ação política e, em última instância, ao conflito.

A teoria comumente conhecida em inglês como "relative deprivation theory", aqui traduzida como teoria da privação relativa, enfocaria, na definição de GURR (1971, pg. 23), 'a tensão que se desenvolve da discrepância entre o 'dever ser' e o 'ser'

181 Bourdieu, Pierre. Razones prácticas - Sobre la teoría de la acción. 1997. Barcelona: Editorial Anagrama. Pg. 16.

182 Ibidem.

${ }^{183}$ Ibidem.

${ }^{184}$ GÓIS, Pedro Manuel Rodrigues da Silva Madeira e. A construção secular de uma identidade étnica transnacional: a cabo-verdianidade. Tese de doutoramento. Universidade de Coimbra. Portugal. 2011. Pg. 142. Disponível em https://estudogeral.sib.uc.pt/bitstream/10316/17848/1/tese\%20versão\%20final.pdf. (Consulta realizada em 19/11/2015.) 
da satisfação coletiva, que leva os homens à violência ${ }^{185 \%}$. Em outras palavras, significaria dizer que a distância entre expectativas e realidade levaria ao conflito, caso em que "a base óbvia para mobilização de oposições contra o estado" ${ }^{186}$ seria a etnicidade. Ou, quanto maior o grau de frustração, maior a instabilidade política.

A alusão à "relatividade", que dá nome à tese, diz respeito, assim, à comparação da situação experimentada pelo grupo com a de outros em contato. Não importariam os incrementos à qualidade de vida dos grupos de forma absoluta, quando, de outra parte, em comparação, não atingissem suas expectativas sociais comparativamente. $O$ resultado desta equação seria, novamente, a ação social e política. Neste aspecto, diferencia a doutrina a privação egoística daquela fraternal, a primeira no nível individual e a segunda afeta à coletividade como um todo.

A corrente foi apresentada pioneiramente por Runciman (1966), em estudo sobre movimentos sociais, em que concluiu pela maior probabilidade de grupos com níveis de privação fraterna mais elevados terem de desencadear estratégias de acção colectiva" ${ }^{\text {"187. }}$.

SMITH (1981, pg. 28) já tratava da privação enquanto motor de conflitos étnicos ao analisar os nacionalismos, afirmando que o protesto étnico e o nacionalismo étnico seriam a consequência de privações relativas, em geral voltados para o responsável pela alteração naquela situação, em regra o Estado. ${ }^{188}$ Sem embargo, tecia o autor críticas à sua essência, que soaria, a seu ver, plausível, porém ambígua. Isto porque, primeiramente, poderia haver várias formas de privação - econômica, trabalhista, condições de saúde, etc - de modo que não haveria evidencias de que pessoas em uma região sofressem de todas elas ao mesmo tempo, ou que seu efeito no comportamento político do grupo fosse uniforme. Ainda, acreditava o autor que demandas políticas

${ }^{185}$ Gurr, Ted. R. (1971).Why Men Rebel, New Jersey: Princeton University Press. 1971. Pg. 23. Apud SALEH, Alam. Relative Deprivation Theory, Nationalism, Ethnicity and Identity Conclicts. Geopolitics Quarterly, Volume 8, n. 4, winter 2013. Pg. 165. Disponível em: http://www.sid.ir/en/VEWSSID/J_pdf/108020132807.pdf (consulta realizada em 20/11/2015).

186 Ibidem.

${ }^{187}$ RUCIMAN, W. G. Relative Deprivation and Social Justice, Londres, Routledge et Kegan Paul. 1966. Apud. VALA, Jorge; LIMA, Maria Luísa \& MONTEIRO, Maria Benedicta. Conflitos intergrupais em contexto organizacional: problemas de investigação e de intervenção - estudo de um caso. Análise Sociaal, vol. XXIII (99), 1987-5, 801-814. Pg. 86. Disponível em: http://analisesocial.ics.ul.pt/documentos/1223028279U3eRE3ni0Qn02JI5.pdf (Consulta realizada em 20/11/2105).

188 SMITH, Antony. The Ethnic Revival in the Modern World. Cambridge University Press. 1981 The Etnic Revival - Antony D. Smith. Pg. 28. 
teriam maior importância que a econômica na mobilização étnica. Por fim, afirmava que existiria um gap entre a privação de recursos e a mobilização política, o que exigiria um “clima político", nem sempre existente.

Com efeito, neste sentido afirmava o autor que "nacionalistas talvez enquadrem seus apelos em termos econômicos; mas o centro de seus reclames permanecem psicológico e político, ao contrário de econômico". ${ }^{189}$

De fato, como admite o pensador, a teoria teria um papel complementar na explicação dos fenômenos étnicos, podendo notar-se mobilização política onde não há significativa discrepância naquelas condições, a exemplo das reivindicações observadas na Catalúnia, que vivencia relativa prosperidade econômica. De maneira análoga, grandes abismos econômicos na Iugoslávia foram testemunho de passividades de grupos étnicos durantes longos períodos.

No que tange à caracterização da etnicidade, não há inovações quanto às correntes modernistas acima trazidas. Sua contribuição estaria na acentuação da etnicidade como canalizadora das insatisfações em face do Estado. Segundo prega, o mero senso de privação, por si só, não gera a mobilização social, precisando haver a politização do mesmo.

Os grupos étnicos seriam, sob este viés, pontos de referência na construção das expectativas, as quais, uma vez frustradas, levariam ao sentimento de privação e à consequente mobilização social. Mais do que isto, realçam seus partidários o papel do contraste entre grupos, suas posições econômicas e sociais e o sentimento de desprestígio como motor dos levantes sociais:

A teoria da privação relativa foca em sentimentos e ações. Por exemplo, a teoria incentiva a explorar os sentimentos individuais de privação que possam resultar da comparação de sua situação com a de outra pessoa ou grupo de referência, bem como os efeitos comportamentais dos sentimentos de privação. ${ }^{190}$

Sob o olhar desta teoria, o conflito, enquanto resultado, somente teria lugar diante da soma de interesses econômicos e do contexto étnico, o que dá amparo à

\footnotetext{
${ }^{189}$ Ibidem.

${ }^{190}$ FLYNN, Simone I. Relative Deprivation Theory. Sociology Reference Guide. Pg. 100. Disponível em https://wiki.zirve.edu.tr/sandbox/groups/economicsandadministrativesciences/wiki/0edb9/attachments/0d 145/Flynn.pdf?sessionID=8940d4002f706e131a7b4041f136555e3b9837d4. (Consulta realizada em 20/11/2015).
} 
hipótese ora sustentada de que a confluência da proteção cultural e econômica na autoidentificação seria o motor dos conflitos observados.

Ainda, coerentemente com a hipótese aventada, a privação não necessitaria ser, segundo aquelas formulações, exclusivamente econômica. Privações de ordem política também poderiam engendrar o conflito. Dentre as causas, elenca FREEMAN, a exclusão ou desvantagens em processos políticos, o que, por sua vez identifica-se, por exemplo, com a carência de autonomia política percebida nas Resex, que se combina com a carência econômica. ${ }^{191}$

Neste sentido é que o termo privação se diferenciaria de pobreza, mais se aproximando da ideia de desigualdade. A etnicidade seria o mecanismo utilizado para que se atingisse tais objetivos de aproximação, devido, sobretudo, às suas qualidades carismáticas, de fácil agregação. Seria, assim, a junção da etnicidade com a privação política-econômica o combustível para a ação política.

Ainda segundo a teoria,

\begin{abstract}
A principal causa da politização da identidade étnica é a situação em que um Estado não responde às suas demandas. Quanto mais um Estado ignora as expectativas do grupo étnico, mais frustrados e privados estes grupos restarão. Enquanto sociedades democráticas e prósperas são menos propensas a enfrentar violência étnica, a falta de Liberdade de expressão, censura à imprensa e a prevalência de pobreza criam grandes oportunidades para a politização da identidade social contra o autoritarismo, particularmente quando um regime mostra-se incapaz de atender às demandas sociais. ${ }^{192}$
\end{abstract}

Conforme se depreende, a relative deprivation theory contribui na compreensão do fenômeno ora enfrentado, na medida em que salta aos olhos a distinção no tratamento entre as populações indígenas e tradicionais. Tal relação, entre recursos materiais e identidades, seria também abordada sob outros viéses, como o abaixo abordado.

\footnotetext{
${ }^{191}$ FREEMAN, Diane. An Explanation of Conflict: Ethnicity, Deprivation, and Rationalization. Kentucky Political Science Association Conference. 2015. Pág. 01.

192 SALEH, Alam. Relative Deprivation Theory, Nationalism, Ethnicity and Identity Conflicts. Geopolitics Quarterly, Vol. 8. Pg. 170.
} 


\section{Cap. 4.2. Reconhecimento $x$ Redistribuição e a Territorialização das Identidades.}

A relação entre identidade étnica e políticas públicas, ou a satisfação de necessidades econômicas e sociais é tema de grande interesse nas ciências políticas, perpassando por debates em torno da formação de preferências, modelos de Estado Democrático, entre outras relevantes discussões.

Os estudos acerca desta relação dividem-se em duas escolas de pensamentos ${ }^{193}$. A primeira delas afirma que a manutenção da diversidade étnica impede a redistribuição de bens públicos, criticando, assim, Estados com políticas paternalistas em relação a estas populações. Uma segunda, e mais moderna doutrina tem pregado, ao contrário, que políticas positivas podem tornar as diferenças étnicas mais nítidas ${ }^{194}$.

O debate vem demonstrar a complexidade na definição de políticas públicas a grupos em situação de vulnerabilidade, em especial apontando seu papel na reprodução das desigualdades, nisto interessando ao presente trabalho.

FRASER (1997), na formulação de sua teoria da justiça, dedicou-se à situação de grupos minoritários, às consequências de políticas positivas, e à relação entre redistribuição e reconhecimento, buscando a conciliação entre remédios para assimetrias econômicas e sociais e aqueles voltados para o reconhecimento ${ }^{195}$.

Segundo a autora, "a luta por reconhecimento está rapidamente se tornando a forma paradigmática de conflito político no final do século XX”196. A identidade de grupo teria, assim, substituído a de classes no mundo pós-socialismo, na medida em que a dominação cultural suplanta a exploração.

\footnotetext{
${ }^{193}$ CHANDRA, Kanchan. Constructivist Theories of Ethnic Politics. Oxford University Press. 2012. Pg. ${ }^{194}$ CORSTANGE, Daniel. Institutions and Ehnic Politics in Leanon and Yemen. University of Michigan. 2008. Pg. 131

195 FRASER, Nancy. Da redistribuição ao reconhecimento? Dilemas da justiça na era pós-socialista. Outledge, Nova York, 2006.

196 FRASER, Nancy. Da redistribuição ao reconhecimento? Dilemas da justiça na era pós-socialista. Outledge, Nova York, 2006. Pg. 231.
} 
Tais lutas, entretanto, acontecem em um cenário também dominado por desigualdades materiais, donde advém o desafio de se desenvolver uma teoriza crítica do reconhecimento que identifique e assuma a defesa somente daquelas versões da política cultural da diferença que possam ser combinadas coerentemente com a política social da igualdade.

A autora lida, assim, com a compexidade do mundo contemporâneo, onde demandas por mudanças culturais mesclam-se a demandas por mudanças econômicas.

A ampliação do senso de justiça no atual estágio democrático perpassaria pela cidadania equitativa e pela igualdade de status $^{197}$, exigindo tanto reconhecimento quanto distribuição. Com isto, investiga a pensadora "como conceituar reconhecimento cultural e igualdade social de forma a que sustentem um ao outro, ao invés de se aniquilarem (pois há muitas concepções concorrentes de ambos)”. E principalmente, busca esclarecer "os dilemas políticos que surgem quando tentamos combater as duas injustiças ao mesmo tempo ${ }^{198}$.

Há de se distinguir para tanto justiça econômica de justiça cultural, ou simbólica, que teria como base padrões sociais de representação, interpretação e comunicação. A injustiça cultural, ou simbólica, seria expressa pela dominação culural, o ocultamento, o desrespeito, etc.

Em que pese o mútuo entrelaçamento, tais formas de injustiça devem ser bem distinguidas, uma vez que cada uma delas é sanada por meio de remédios próprios. O remédio para a injustiça econômica seria a reestruturação político-econômica, o que poderia significar redistribuição de renda, reorganização da divisão do trabalho, controles democráticos do investimento ou a transformação de outras estruturas econômicas básicas. Já o remédio para a injustiça social consiste em mudanças sociais ou simbólicas, como a revalorização de identidades, reconhecimento e valorização positiva da diversidade cultural ou uma transformação abrangente dos padrões sociais de representação, interpretação e comunicação.

\footnotetext{
${ }^{197}$ FERREIRA, Walace. Justiça e reconhecimento em Nancy Fraser: interpretação teórica das ações afirmativas no caso brasileiro. Pg. 03. Disponível em: http://www.cp2.g12.br/UAs/se/departamentos/sociologia/pespectiva_sociologica/Numero4/Artigos/walla ce.pdf (consulta realizada em 20/11/2015).

${ }^{198}$ FRASER, Nancy. Da redistribuição ao reconhecimento? Dilemas da justiça na era pós-socialista. Outledge, Nova York, 2006. Pg. 231.
} 
Enquanto os remédios por reconhecimento promovem a diferenciação do grupo, os remédios de redistribuição buscam em regra reduzir as diferenças.

Debruçando-se sobre a questão, FRASER (2006, pg. 231) assim refletia:

"Eis, então, um difícil dilema. Doravante vou chamá-lo dilema da redistribuiçãoreconhecimento. Pessoas sujeitas à injustiça cultural e à econômica necessitam de reconhecimento e redistribuição. Necessitam ambos para reivindicar e negar sua especificade. Como é possível? ${ }^{199}$

Quando se está diante de grupos que estão nas extremidades - ou seja, só pleiteiam reconhecimento ou redistribuição -, a questão se mostra mais fácil de solucionar. Ao contrário, quando os grupos possuem ambas as carências, chamados por isto ambivalentes, nenhum dos remédios por si só tem o condão de solucionar o problema. Exemplos seriam os grupos oprimidos por gênero ou raça. Neste sentido, por exemplo, as feministas buscariam remédios que:

\begin{abstract}
"dissolvam a diferenciação de gênero, enquanto buscam também remédios culturais que valorizem a especificidade de uma coletividade desprezada. Os anti-racista, da mesma maneira, devem buscar remédios econômico-políticos que dissolvam a diferenciação 'racial', enquanto buscam também remédios culturais que valorizem a especificidade de coletividades desprezadas. Como podem fazer as duas coisas ao mesmo tempo?"200
\end{abstract}

Remédios afirmativos seriam voltados para corrigir efeitos desiguais de arranjos sociais sem modificar a estutura que os engedra. Já os transformativos seriam voltados para corrigir efeitos por meio da transformação estrutural.

Para a autora,

"A política de identidade gay trata a homossexualidade como uma positividade
cultural, com seu próprio conteúdo substantivo, muito semelhante à etnicidade (ou à
visão de senso comum desta). Assume-se que essa positividade subsiste em si e de si
mesma, necessitando somente de reconhecimento adicional". Já os transformativos,
tratariam da homossexualidade "como um correlato construído e desvalorizado da
heterossexualidade; ambas são reificações da ambiguidade sexual e são co-definidas
somente uma em relação à outra. O objetivo transformativo não é consolidar uma
identidade gay, mas desconstruir a dicotomia homo-hétero de modo a desestabilizar
todas as identidades sexuais fixas. A questão não é dissolver toda a diferença sexual
numa identidade humana única e universal; mas sim manter um campo sexual de
diferenças múltiplas, não binárias, fluidas, sempre em movimento.

Se de um lado as políticas afirmativas tendem a promover as diferenciações dos grupos existentes, os remédios de reconhecimento buscam abrir espaços para novos

\footnotetext{
${ }^{199}$ Ibidem. Pg. 233.

${ }^{200}$ Ibidem. Pg. 236.

${ }^{201}$ Ibidem. Pg. 237.
} 
reagrupamentos no futuro. No campo das injustiças econômicas, a distinção também é válida. Os remédios afirmativos buscariam compensar a má distribuição histórica de recursos, enquanto os transformativos buscariam a transformação do sistema capitalista.

Portanto, longe de ocuparem esferas separadas, injustiça econômica e injustiça cultural normalmente estão imbricadas, dialeticamente, reforçando- se mutuamente. Normas culturais enviesadas de forma injusta contra alguns são institucionalizadas no Estado e na economia, enquanto as desvantagens econômicas impedem participação igual na fabricação da cultura em esferas públicas e no cotidiano. O resultado é freqüentemente um ciclo vicioso de subordinação cultural e econômica. ${ }^{202}$

Conforme alerta a teórica, os remédios afirmativos ajudam os grupos necessitados, mas criam diferenciações de grupo fortemente antagônicas, deixando intactas as estruturas.

Com este raciocínio indaga FRASER (2006, pg. 239):

no que diz respeito aos grupos submetidos aos dois tipos de injustiças, qual será a combinação de remédios que funciona melhor para minimizar, senão para eliminar de vez, as interferências mútuas que surgem quando se busca redistribuição e reconhecimento ao mesmo tempo? ? $^{203}$

Estudando de perto os conflitos entre tradicionais e indígenas em Reservas Extrativistas, ALMEIDA \& REZENDE (2013, pg. 192), apontariam sua origem nas políticas de redistribuição de recursos, assim sustentando:

Há quem defenda o argumento de que conflitos internos entre moradores de Reservas Extrativistas, incluindo-se neles a frequente reivindicação de reconhecimento como "indígenas" ou "quilombolas", é consequência da proliferação de identidades induzidas por políticas públicas. Segundo essa visão, a raiz do problema é um suposto Estado Multiculturalista. Sob esse argumento, o Estado Multiculturalista exigiria de comunidades locais a auto-identificação sob "identidades" excludentes entre si, gerando conflitos entre facções locais que poderiam classificar-se como pertencentes ao mesmo tempo a diversas categorias étnicas. A obrigação de adotar uma única categoria como dominante seria a causa de confl itos locais.

Com esse argumento, busca-se no fundo criticar as próprias Terras Indígenas, os Territórios Quilombolas, e as Reservas Extrativistas, e ainda os Assentamentos Extrativistas, como formas de distribuição de direitos com base em critérios identitários.

\footnotetext{
${ }^{202}$ FERREIRA, Walace. Justiça e reconhecimento em Nancy Fraser: interpretação teórica das ações afirmativas no caso brasileiro. Pg. $255 . \quad$ Disponível em: http://www.cp2.g12.br/UAs/se/departamentos/sociologia/pespectiva_sociologica/Numero4/Artigos/walla ce.pdf (consulta realizada em 20/11/2015).

203 FRASER, Nancy. Da redistribuição ao reconhecimento? Dilemas da justiça na era pós-socialista. Outledge, Nova York, 1997. Pg. 239
} 
A alternativa a tais políticas seriam políticas sociais universais, sob as quais direitos territoriais ou sociais não dependeriam de "identidades" étnicas ou territoriais ${ }^{204}$.

Intimamente ligado a este debate está aquele atinente à associação entre a identificação étnica e a concessão de terras. OLIVEIRA (2004, pg. 13) apontou em estudos sobre os "índios do Nordeste" a "conexão indissociável entre "processo de territorialização' e a 'etnicidade" ${ }^{205}$. Na visão do autor, "Ambos são vistos como fenômenos de ordem política e que têm, na vinculação a limites territoriais geridos pelo Estado, um aspecto chave de sua existência", mas, exatamente por isso, a "identidade étnica deve ser pensada no contexto dos processos políticos por meio dos quais ela é constituída, sendo o Estado e suas políticas de gestão territorial um agente central"206.

Ainda segundo PANTOJA, COSTA \& ALMEIDA (2011, pg. 128):

A circunscrição de "comunidades indígenas" a um território é um ato político que as transforma em coletividades organizadas, com identidades formuladas, com suas instâncias próprias de poder e seu patrimônio cultural, que é reestruturado em função da nova situação. ${ }^{207}$

A principal utilidade da abordagem trazida por Fraser para o presente trabalho diz respeito à tentativa da autora de responder às seguintes perguntas:

Em que circunstâncias uma política de reconhecimento pode apoiar uma política de redistribuição? Quando é provável que a enfraqueça? Qual das variedades de política da identidade mais se adéqua a lutas por igualdade social? E qual dentre elas tende a interferir com essa última? Com isso, sua preocupação relacionada a essas questões consiste na relação entre reconhecimento da diferença cultural e a desigualdade social. $^{208}$

Por trás das indagações estaria o temor de que a conexão entre os remédios acabasse por gerar efeitos colaterais na ação do Estado, temor este que reforça a

\footnotetext{
204 ALMEIDA, Mauro W. Barbosa e REZENDE, Roberto Sanches. Uma Nota sobre Comunidades Tradicionais e Unidades de Conservação. Revista do Centro de Estudos Rurais - UNICAMP 2013. São Paulo. V. 7, n2. Pg. 192.

205 OLIVEIRA, João Pacheco (org.). Etnicidade, política e reelaboração cultural no Nordeste indígena. Rio de Janeiro: Contra Capa Livraria/LACED, 2004, pg. 213, Apud PANTOJA, Mariana C., COSTA, E. M. L \& ALMEIDA, M. W. B. de 'Teoria e prática da etnicidade no Alto Juruá Acreano. Revista Raizes, no prelo. Pg. 128.

${ }^{206}$ Ibidem.

${ }^{207}$ PANTOJA, Mariana C., COSTA, E. M. L \& ALMEIDA, M. W. B. de 'Teoria e prática da etnicidade no Alto Juruá Acreano. Revista Raízes, v.31, 2011. Pg. 128

208 FERREIRA, Walace. Justiça e reconhecimento em Nancy Fraser: interpretação teórica das ações afirmativas no caso brasileiro. Pg. $04 . \quad$ Disponível em: http://www.cp2.g12.br/UAs/se/departamentos/sociologia/pespectiva_sociologica/Numero4/Artigos/walla ce.pdf (consulta realizada em 20/11/2015).
} 
hipótese edificada no presente trabalho. Isto é, a garantia pelo Estado de remédios que valorizam a identidade de povos tradicionais e indígenas estaria contaminada pela presença de remédios para carências econômicas sociais.

Os casos abaixo descritos demonstram assim a presença de alguns elementos fáticos coincidentes: autorreconhecimento recente como indígenas; populações já contempladas com Reservas Extrativistas e demais programas voltados às populações tradicionais; assimetria de recursos, políticos, econômicos e sociais (privação relativa); a possibilidade de mitigação de tal assimetria pela via do autorreconhecimento como indígenas. É o que se vê adiante. 


\section{Cap. 5. Estudo de Casos}

Cap. 5.1. Reserva Extrativista do Alto Juruá e Terra Indígena Arara do Rio Amônia

"Faço saber aos senhores, um pouco da realidade do dia-adia, na comunidade Arara do rio Amônia, liderada pelo Sr. Francisco Ciqueira, conhecido como Chiquim da Ilda, e pedir desde já a retirada de nosso nome que se inclui na lista de índios Apolima Arara do Rio Amônia, pois estávamos melhora antes do que agora, por isso, decidimos que queremos continuar como sempre foi antes da invenção da Aldeia Apolima Arara." ${ }^{209}$ (grifos nossos)

A Reserva Extrativista do Alto Juruá, localizada no Estado do Acre, destaca-se como a primeira Reserva Extrativista criada no Brasil, na sequência do primeiro Encontro da Aliança dos Povos da Floresta, onde fora enfaticamente reivindicada.

Vinda ao mundo jurídico por meio do Decreto $\mathrm{n}^{\circ}$ 98.863, de 23 de janeiro de 1990, já em sua criação a Reserva contava com cerca de 900 famílias extrativistas, em sua área total de 506 mil hectares ${ }^{210}$.

Conforme relata PANTOJA, na ocasião da implantação da Reserva, "seus moradores 'tradicionais' eram representados pela Associação dos Seringueiros e Agricultores da Reserva Extrativista do Alto Juruá, sem se confundirem com os moradores das Terras Indígenas contíguas com a Reserva"211. A estudiosa, atenta às pecularidades étnicas da região, assim tecia breve relato do histórico que daria origem ao intrincado mosaico étnico:

“O vale do alto rio Juruá e sua vizinhança é uma região historicamente ocupada por povos indígenas do tronco linguístico Pano, conforme os registros históricos mais antigos. (TASTEVIN, 2009) Esses grupos, a partir de finais do século XIX, foram expulsos, perseguidos, mortos ou capturados em consequência de levas sucessivas de

\footnotetext{
${ }^{209}$ Trecho de missiva enviada por moradores do Alto Juruá, ao longo do conflituoso processo de criação da Terra Apolima-Arara.

${ }^{210}$ PANTOJA, Mariana C., COSTA, E. M. L \& ALMEIDA, M. W. B. de 'Teoria e prática da etnicidade no Alto Juruá Acreano. Revista Raízes, v.31, 2011. Pg. 120.

${ }^{211}$ Ibidem.
} 
migrantes (nordestinos e cearenses, em sua grande maioria) que visavam a ocupação econômica das ricas florestas de terra firme para produção de borracha. Muitas etnias indígenas foram dadas como desaparecidas nesse processo (RIBEIRO, 1979). Os patrões dos seringais organizavam as chamadas 'correrias', expedições armadas que cercavam e invadiam as malocas indígenas, a pretexto de retaliar ataques indígenas ou simplesmente para tomar seus territórios, dizimando seus moradores, mas também aprisionando mulheres e crianças (WOLFF, 1999; PANTOJA, 2008; IGLESIAS, 2010).

No mesmo período, povos indígenas oriundos do vale do Ucayali, no Peru, pertencendo ao tronco linguístico Arawak, migraram para o vale do Juruá, enquanto parte dos povos do tronco Pano refugiou-se nas cabeceiras dos afluentes do Juruá e do Purus, alguns em território peruano, para escapar às 'correrias' (IGLESIAS, 2010). Essa movimentação de povos autóctones e migrantes em um tempo de violência deu origem ao atual mosaico étnico que caracteriza a região. Entre esses povos indígenas deslocados e os migrantes de origem nordestina ocorreram uniões conjugais, e hoje em dia muitas famílias de seringueiros contam com ascendentes indígenas, sobretudo mulheres raptadas enquanto crianças, em meio ao massacre de aldeias inteiras (WOLFF, 1999 PANTOJA, 2008). Em todo o Estado do Acre o termo 'caboclo' é utilizado como referência àqueles que se auto-identificam como tais, quanto em relação aos descendentes dessas uniões conjugais entre povos nativos e migrantes nordestinos. Os 'caboclos' são contrastados com os 'cairús', como 'índios' em relação a 'brancos'. ${ }^{212}$

No final da década de 1990 e início da década seguinte, dois movimentos de autoidentificação surgiram na forma de pleitos por Terras Indígenas que, uma vez criadas, sobrepor-se-iam à Reserva: o povo autodenominado Arara (posteriormente intitulado "Apolima-Arara"), e os Kuntanawa.

De acordo com explicações de PANTOJA, "os Arara e os Kuntanawa assemelham-se por serem compostos de 'caboclos' no sentido regional, isto é, por contarem entre seus antepassados sobreviventes de povos indígenas que escaparam à perseguição e destruição física e cultural" ${ }^{\prime 213}$. Ambos os grupos teriam perdido sua língua e formas de organização social, constituindo-se por casamentos com migrantes nordestinos, ressurgindo somente nos anos recentes como grupos etnicamente autoidentificados.

Os Apolima-Arara congregam grupo formado por diferentes troncos familiares. Dentre eles estariam ascendentes dos Kaxinawá, dos Arara do rio Bagé, dos Chama/Conibo do Ucayali e dos Santarrosinos, "unidos todos por várias uniões com descendentes de migrantes nordestinos que passaram a residir ao longo do último

\footnotetext{
${ }^{212}$ PANTOJA, Mariana C., COSTA, E. M. L \& ALMEIDA, M. W. B. de 'Teoria e prática da etnicidade no Alto Juruá Acreano. Revista Raízes, v.31, 2011. Pg. 119

${ }^{213}$ Ibidem, pg. 121.
} 
século, no alto curso do rio Amônia, sem formar um único grupo de parentesco ou unidade política",214

Em 1999, isto é, nove anos após a criação da Reserva, iniciou-se processo de identificação e delimitação da Terra Indígena Arara por provocação do Conselho Indigenista Missionário à Funai. Em notificação expedida, afirmava que famílias denominadas Apolima viviam nas duas margens do Rio Amônia, ocupando, na margem esquerda terras pertencentes à Reserva Extrativista, bem como ao Projeto de Assentamento Agrário Amônia ${ }^{215}$. Quando instada, teria a Funai manifestado surpresa com a presença do povo até então desconhecido, tendo em conta que ali desenvolvia a entidade federal trabalhos na região desde os anos 1980.

No ano seguinte a Funai produziria documento citando a presença de 114 indígenas "localizados nas margens do rio Amonêa [sic] e na margem direita do alto rio Juruá" 216 . Ao que se conhecia, Apolima seria o nome de uma localidade, possivelmente no Peru, e não propriamente o nome de uma etnia ${ }^{217}$.

A partir daquele impulso inicial foi constituído Grupo de Trabalho de Identificação e Delimitação da "Terra Indígena Arara do Alto Juruá", com relatório finalizado em 2003, já constando o nome da desejada área como Terra Indígena Arara do Rio Amônia. A proposta viria a ser rejeitada pelas lideranças indígenas, por não reconhecer que a área sobreposta à Reserva Extrativista seria ocupada tardicionalmente pelo grupo Arara, ensejando o envio de nova equipe à localidade, especialmente para modificação do capítulo da proposta que tratava dos limites da Terra Indígena.

Um segundo laudo antropológico seria então produzido, contrastando-se com o anterior, apontando a área sob disputa como historicamente ocupada pelos demandantes. Finalizado o relatório, decorrer-se-iam anos sem novos eventos, o que impulsionaria o ajuizamento de Ação Civil Pública pelo Ministério Federal pleiteando a conclusão do processo delimitatório e demarcatório.

\footnotetext{
${ }^{214}$ Ibidem.

215 REZENDE, Roberto Sanches \& POSTIGO, Augusto. Reconhecimentos Territoriais e Desconhecimentos Institucionais. Revista do Centro de Estudos Rurais - UNICAMP 2013. São Paulo. V. $7, \mathrm{n} 2$.

${ }^{216}$ Ibidem.

${ }^{217}$ Ibidem.
} 
Pressionada pela ação judicial em curso, reavaliou a Funai a documentação que já havia sido produzida, concluindo, desta vez, pela contraditoriedade dos dois relatórios iniciais e necessidade de produção de um terceiro. Com base neste, seria publicado Resumo do Relatório Circunstanciado dos Estudos de Identificação e Delimitação da Terra Indígena-RCID Arara do Rio Amônia, sob polêmica de não ter o antropólogo responsável pelo laudo final visitado a área da Terra Indígena, bem como consultado a população $^{218}$.

Com efeito, vizinha à proposta Terra Indígena Arara do Rio Amônia encontra-se a já homologada Terra Indígena Kampa do Rio Amônia ${ }^{219}$, habitada pelos índios Ashaninka, ou Kampa. REZENDE \& POSTIGO (2013, pg. 130) resgatam que quando da criação desta, estaria ela "destinada à habitação tanto dos Ashaninka como de outros povos indígenas que, à época do processo demarcatório foram identificados pela Funai como 'kampa não-tradicionais ${ }^{220}$.

O heterogêneo grupo então chamado de "kampa não-tradicionais" seria o "resultado da miscigenação [sic] de Kampa, Amoaca, Santa Rosa, e Xama", "deculturados" e com "separação entre os dois grupos, cultural e espacial",221. Dentre os indivíduos que viriam a se autointitular Apolima-Arara estariam, segundo alegam seus opositores, Kampas não-tradicionais, já contemplados com direitos territoriais na Terra Indígena Kampa.

Assim também observaram REZENDE \& POSTIGO, que alertavam que "os atuais Arara já haviam sido considerados indígenas pela FUNAI na criação da TI Kampa, tendo seus direitos territoriais assegurados com aquela demarcação" ${ }^{\text {222 }}$. Apesar disso, teriam deixado a área da TI Kampa e adentrado na Reserva Extrativista e área do

218 REZENDE, Roberto Sanches \& POSTIGO, Augusto. Reconhecimentos Territoriais e Desconhecimentos Institucionais. Revista do Centro de Estudos Rurais - UNICAMP 2013. São Paulo. V. $7, \mathrm{n} 2$, pg 130.

${ }^{219}$ Homologada em 23/11/1992.

220 REZENDE, Roberto Sanches \& POSTIGO, Augusto. Reconhecimentos Territoriais e Desconhecimentos Institucionais. Revista do Centro de Estudos Rurais - UNICAMP 2013. São Paulo. V. 7, n2, pg 130 .

${ }^{221}$ COUTINHO JUNIOR, 2003, p. 52 apud REZENDE, Roberto Sanches \& POSTIGO, Augusto. Reconhecimentos Territoriais e Desconhecimentos Institucionais. Revista do Centro de Estudos Rurais UNICAMP 2013. São Paulo. V. 7, n2, pg 131.

222 REZENDE, Roberto Sanches \& POSTIGO, Augusto. Reconhecimentos Territoriais e Desconhecimentos Institucionais. Revista do Centro de Estudos Rurais - UNICAMP 2013. São Paulo. V. 7, n2, pg 130) 
Projeto de Assentamento agrário do Rio Amônia em momento posterior àquela demarcação, pleiteando Terras próprias.

A própria Funai se manifestou, em sentido análogo, aduzindo que o "novo" povo Apolima já havia em parte sido identificado e contemplado com Terra Indígena no passado. Tendo sido expulso da Terra Indígena Kampa nos anos que se seguiram à sua criação, haviam se reorganizado sob o nome Apolima-Arara unindo-se a outros grupos. Sob a nova identidade, teriam eles inicialmente buscado o retorno à Terra Indígena Kampa, e em seguida a demarcação de um território próprio ${ }^{223}$.

De sua parte, os extrativistas beneficiários da Reserva também sustentavam que “já haviam sido retirados do Alto Amônia, quando da criação da TI Kampa, e que agora estariam novamente sob o risco de expulsão de suas terras para a criação de outra TI". O histórico revelava, assim, que após a criação da Terra Indígena Kampa, indígenas e não indígenas deixariam seus limites para ingressar na área da Reserva, criada poucos anos antes, com uma diferença: os indígenas haviam sido contemplados com a Terra Indígena, os não-indígenas haviam sido indenizados (por meio do processo de desintrusão).

À origem e lugar comum somava-se ao interrelacionamento entre as populações no âmbito social, gerando uma "rede intrincada de parentesco na região". Com efeito, juntamente com os "Kampa não-tradicionais" estariam também à frente do novo movimento aqueles indivíduos considerados não-índios por ocasião das demarcações anteriores, e que por isto haviam adentrado na Reserva. É o que afirma COUTINHO JÚNIOR (2003, pg. 107),

“'a atual população Arara do rio Amônia’ possui, na verdade, diversas procedências
étnicas. [...] Além dos grupos indígenas acima nomeados, há também um razoável
contingente de não índios vinculados no presente por relações de casamento e afinidade
aos Arara do Amônia. A dinâmica e as limitações criadas por essa forma específica de
composição social, manifestam-se naturalmente em qualquer consideração sobre a
realidade contemporânea dessa comunidade indígena"224.

A pluralidade étnica que caracteriza os Arara era também alertada em "carta dos seringueiros e agricultores do Rio Amônia, Asareaj e Assentamento Asamônia”:

${ }^{223}$ COUTINHO JUNIOR, 2003, p. 143, apud REZENDE, Roberto Sanches \& POSTIGO, Augusto. Reconhecimentos Territoriais e Desconhecimentos Institucionais. Revista do Centro de Estudos Rurais UNICAMP 2013. São Paulo. V. 7, n2, pg 132).

${ }^{224}$ Ibidem. 
“ao médio [Juruá] se concentra uma população de umas 100 famílias todas de seringueiros e agricultores que estão sendo ameaçados de perderem suas moradias para criação de uma nova aldeia esses povos são uma quantia de mais ou menos 48 família entre essas famílias de cada 10 pessoas 8 é branco, mestiço, negro, peruano ou é índio de uma étnia com aldeia já registrada no Estado do Acre, todas essas famílias mistruradas através de casamento com diversas outras raças querem agora formar uma etnia só, chamada Arara e para essa formação querem tirar todas as outas famílias de seringueiros e agricultores que moram nessa extensão do médio Amônia a mais de um centenário".

\section{O histórico é assim relatado na mesma missiva:}

"Relembro aqui senhores (as) uma História que conhecemos a mais de um século atrás, os paraibanos e cearences vindos de suas terras natal para o Acre com o encejo (sic) de ficarem ricos com a extração do látex (leite de seringa), e dos quais somos descendentes e conhecemos a história de muitos desses do passado, travaram nessa mesma região de Thaumaturgo uma batalha de morte contra peruanos que ocupavam essa região da foz do Rio Amônia, não era índio arara que ocupava essa região quando houve essa batalha era peruanos e só depois apareceram os índios vindos das cabeceiras do Juruá no peru e de outros afluentes em territórios brasileiros e peruanos, só quando o Rio Amônia já estava livre de presenças peruanas que tinham seu posto localizado na foz do Rio Amônia e a prova se fez presente que é um fato histórico a trincheira do refúgio peruano fica dentro da sede e pode ser vista por quem quiser".

Em outra interessante missiva - parcialmetne citada na epígrafe deste capítulo -, assim afirmaram alguns moradores da região, antes identificados como Apolima-Arara, que agora, porém, haviam desistindo do autorreconhecimento como tal:

"Faço saber aos senhores, um pouco da realidade do dia-a-dia, na comunidade Arara do rio Amônia, liderada pelo Sr. Francisco Ciqueira, conhecido como Chiquim da Ilda, e pedir desde já a retirada de nosso nome que se inclui na lista de índios Apolima Arara do Rio Amônia, pois estávamos melhora antes do que agora, por isso, decidimos que queremos continuar como sempre foi antes da invenção da Aldeia Apolima Arara."

\section{(...)}

“pois nós pensávamos uma coisa e é outra bem diferente, queremos paz e união com brancos e não brancos, o que já deu pra perceber que nunca acontecerá naquela mistrura de raças, que brigam entre si. (...) Porque antes de ser inventado essa etnia, nunca ninguém veio atrás de confusão com nós e depois disso, o próprio Sr. Chiquim, já veio com confusão com nós".

Já uma das lideranças dos extrativistas, em carta, assim informava perplexa:

"Não entendemos qual o motivo pelo qual o senhor Francisco Ciqueira e os outros decidiram lutar por uma terra, se todos tinham seus lotes de terra doados pelo INCRA, usufruíam os mesmos direitos e benefícios e abandonaram tudo e passaram a construir uma comunidade na parte de cima da Comunidade Quiéto, no Rio Amônia, com outras que já moravam do lado da reserva tendo também os mesmos direitos e deveres como tem todos os moradores da Reserva Extrativista do Alto Juruá, como podem querer que mais de 100 famílias deixem seus locais para uma minoria (...)”.

Os relatos acima expostos, que representam sintética compilação do vasto material já produzido sobre o caso, demonstram a reemergência recente da identidade 
do grupo Arara, calcada em sinais diacríticos resgatados do passado dos grupos habitantes da região, sejam de origem indígena, cabocla ou branca.

Sem lançar contestação à legitimidade do pleito, o que se pretende destacar do histórico ora trazido à tona é a circunstancialidade da emergência identitária, fruto da organização recente, amparada pelo contexto atual em que a diferenciação do grupo estrativista, mostra-se frutífera para aquela comunidade.

Tal circunstância é também observada no segundo pleito por terra indígena que emerge nos limites da Reserva Extrativista do Alto Juruá abaixo abordado. 
MAPA DA SOBREPOSIÇÃO ENTRE RESEX ALTO JURUÁ E A TERRA INDÍGENA ARARA DO RIO AMÔNIA. MAPA 01

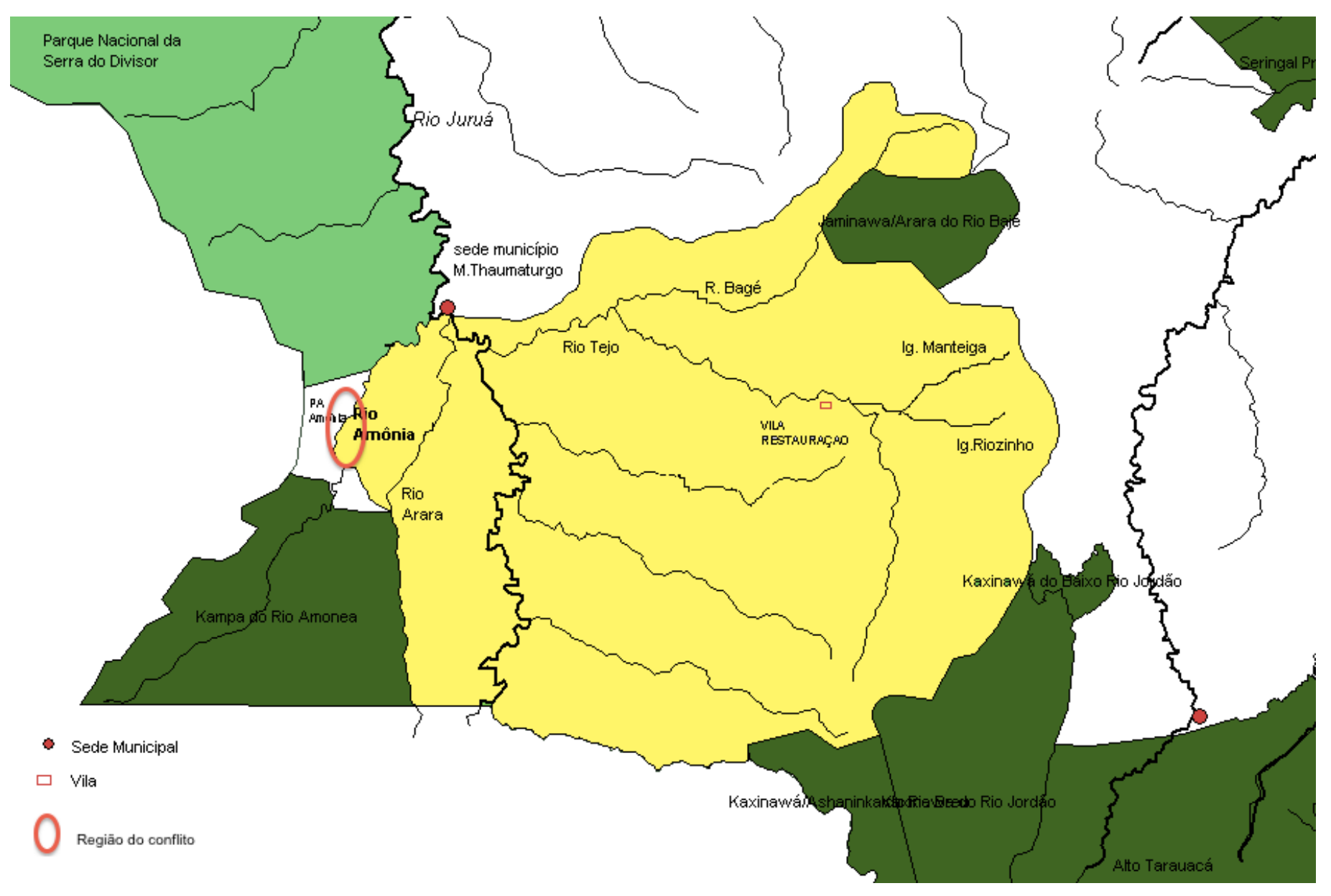




\section{MAPA DA SOBREPOSIÇÃO ENTRE RESEX ALTO JURUÁ E A TERRA INDÍGENA ARARA DO RIO AMÔNIA. MAPA 02}

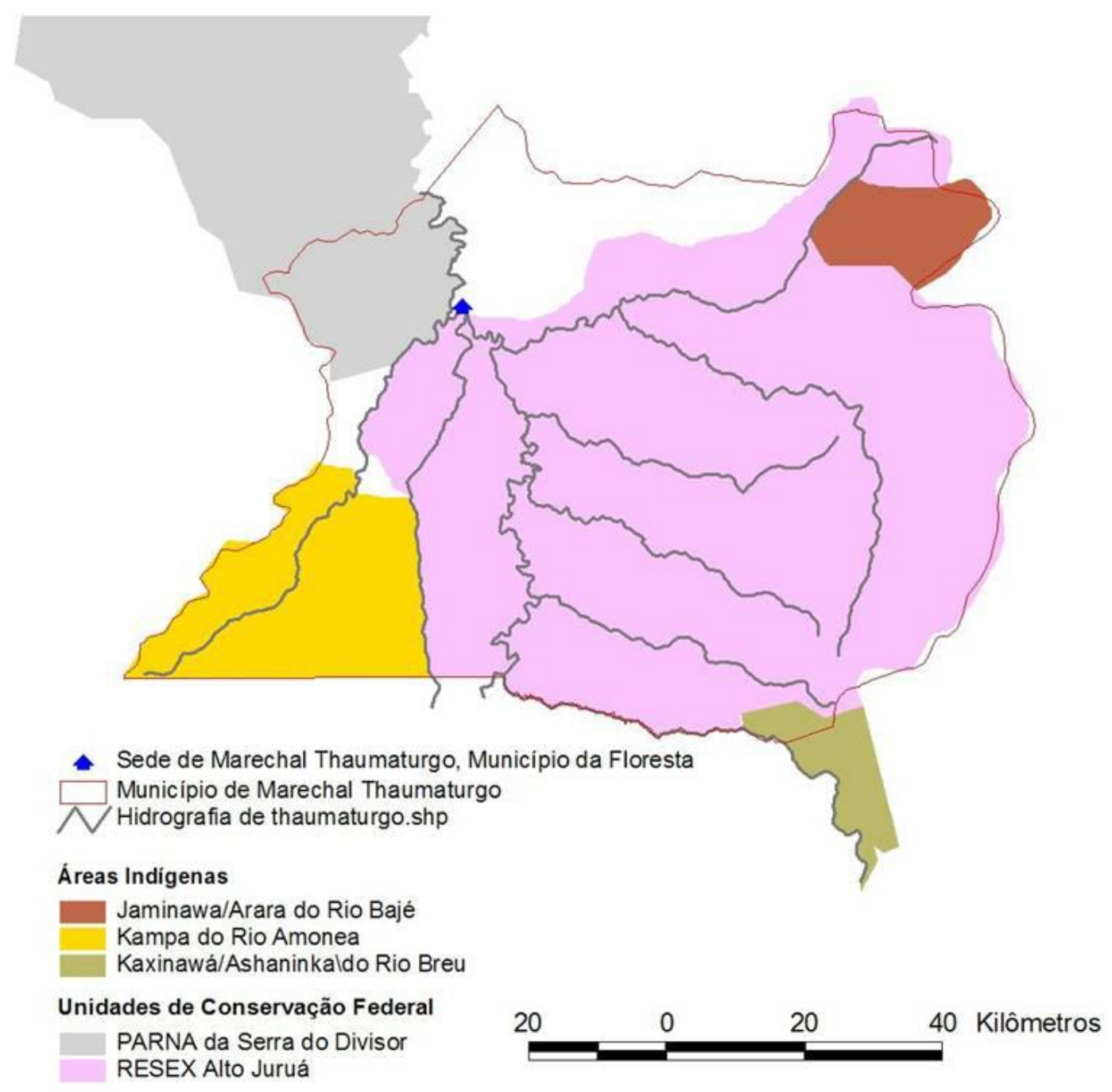

TIs e UCs em Mal. Thaumaturgo (TI Arara e Assentamento - mapa por Augusto Postigo) 


\section{Cap. 5.2. Os Kuntanawa no Alto Juruá}

Ao leste da pleiteada Terra Indígena Arara do Rio Amônia, a Reserva Extrativista do Alto Juruá vivencia, também, conflito ante a demanda pela Terra Indígena Kuntanawa. Sua população, conforme ressalta PANTOJA (2011, pg. 119), surgiu do núcleo da população tradicional já beneficiária da Reserva, através de um processo de "auto diferenciação étnico num contexto em que a população está conectada por redes de parentesco e de vizinhança, recobrindo tanto áreas de floresta como de núcleos urbanos" 225 .

Os Kuntanawa ocupam o alto rio Tejo, afluente da margem direita do Juruá, originando de uma única parentela, ao contrário dos Apolima-Arara. Em seu histórico, teriam passado por “dois processos recentes de 'comuniarização', primeiro passando de 'caboclos' a 'seringueiros', que obtiveram importantes conquistas como 'povos da floresta', e depois passando de 'seringueiros' a 'Kuntanawa',226.

A mesma estudiosa assim descreve o processo de etnogênese daquele grupo:

Os Kuntanawa de hoje são os descendentes de um índio e de uma índia capturados quando crianças, nas matas do rio Envira, por 'correrias', no início do século XX, separados de seus grupos originais e incorporados à sociedade de seringais. A menina índia, batizada pelos 'brancos' de Maria Regina da Silva, viveu praticamente toda sua vida no rio Jordão sob a autoridade de patrões seringalistas, e deu à luz, em 1928, a mulher Kuntanawa mais velha hoje viva, dona Mariana. O menino índio, capturado nos idos de 1900, também cresceu no rio Jordão, onde se casou com uma filha de cearenses migrantes e faleceu em seguida. Desta união nasceu o líder mais velho dos Kuntanawa de hoje, seu Milton, que por volta de 1954, uniu-se conjugalmente com dona Mariana, ainda no rio Jordão. No ano seguinte, o casal estabeleceu-se no rio Tejo, onde pai e filhos trabalharam como seringueiros para patrões até o final dos anos de 1980.

Dona Mariana e seu Milton geraram uma extensa prole que hoje estende-se por seis gerações. Esse extenso grupo de pessoas ligadas por laços de parentesco sob o comando de uma liderança reconhecida (seu Milton), sempre foi conhecido nos seringais como 'caboclos'; ou “os caboclos do Milton”. Dona Mariana era a “cabocla Mariana', e assim por diante. Foi este mesmo grupo que teve ativa e destacada participação nas lutas que resultaram, em 1990, na criação da Reserva Extrativista do Alto Juruá: “os Milton”, como a parentela costumava ser também identificada, forneceram a principal base

\footnotetext{
${ }^{225}$ PANTOJA, Mariana C., COSTA, E. M. L \& ALMEIDA, M. W. B. de 'Teoria e prática da etnicidade no Alto Juruá Acreano. Revista Raízes, v.31, 2011. Pg. 119.

${ }^{226}$ Ibidem. Pg. 121.
} 
política local do Conselho Nacional dos Seringueiros (CNS) no alto rio Tejo, ao lado de famílias no rio Bagééc

Os Kuntanawa são população de contato recente, remontando ao último século, ainda tendo vivos os descendentes diretos da geração que o protagonizou. Durante o século passado teriam perdido seus traços distintivos principais, sendo incorporados à sociedade da borracha, misturando-se aos seringueiros que chegavam à região.

Em dado momento, entretanto, aproximam-se de extrativistas do Alto Tejo e do Alto Juruá que ainda mantinham costumes e organização social ancestrais, com os quais criam o interesse no resgate da cultura de seus antepassados, na comunitarização e na proclamação de sua identidade indígena.

Segundo afirma PANTOJA (2011, pg. 129),

Estes grupos haviam realizado desde a década de 1970, suas próprias trajetórias de conquista de território e de revitalização de conhecimentos, linguagem, rituais e cosmologias. Os Kuntanawa, ao deixarem de ser 'caboclos' para se tornarem 'índios', aliaram-se a esses povos como seus principais interlocutores para 'reaprender' língua, cantos, e ritos. Mas também se utilizam sistematicamente das técnicas xamânicas e dos rituais coletivos para se reconstruírem como entes sociais - em outras palavras, para se reconstruírem no plano ontológico. Desse ponto de vista, adereços plumários e pintura corporal - além de sua importância como marcas diacríticas ou 'cultura' para uso externo, são habitus que fazem pessoas Kuntanawa. ${ }^{228}$

O processo de comunitarização dos Kuntanawa foi assim analisado pela autora, com apoio em Weber, atribuindo ao antagonismo de serigueiros e caboclos o pano de fundo para a constituição da comunidade étnica Kuntanawa. Para ela,

Lembremos, contudo, que na acepção weberiana não são disposições ou habitus que constituem uma comunidade étnica, nem mesmo a percepção subjetiva de que elas existem, e sim a mobilização dessa percepção como referência para a ação social, em particular de cunho político. Esse parece ter sido um componente importante no processo de comunitarização Kuntanawa. Recordemos ainda que a existência de "disposições" e de "habitus" em comum não é uma condição sine qua non para a comunitarização: esta pode começar ativando uma "memória de migração" comum, e só depois reconstituindo um habitus em comum - um processo que pode estar em curso no caso Arara do Amônia.

No caso Kuntanawa, havia um autoreconhecimento pré-existente do grupo inteiro como 'caboclos', que foi sendo acentuando e transformando à medida que passaram a se auto identificar enquanto índios Kuntanawa, e não mais 'caboclos', que não eram sujeitos de direitos. Ao longo desse processo, um habitus de 'caboclos' foi reconstruído, levando a uma reformulação de modos de vestir, a uma nova postura e atitude, e novos modos de pensar.

\footnotetext{
${ }^{227}$ PANTOJA, PG 123

${ }^{228}$ Ibidem, pg. 129.
} 
Identifica-se, assim, no caso dos Kuntanawa recentemente autorreconhecidos, ademais da ancestralidade comum indígena, uma cultura descontinuada que seria reconstruída com apoio no resgate de elementos históricos, tanto quanto tomando de empréstimo elementos culturais das comunidades próximas. Neste curso, revela-se a importância do processo experimentado pelos Kuntanawa de dupla comunitarização, primeiramente passando de caboclos a população tradicional - não apenas unida sob o aspecto profissional, senão também cultural -, o que ensejara a criação da Reserva Extrativista, e em seguida de seringueiros a indígenas.

Registros da criação da Reserva ainda dão conta de grupo então identificado como os "caboclos do Milton", fazendo referência aos descendentes daquele conhecido personagem, que atuaram enfaticamente como seringueiros para a constituição da Unidade de Conservação. Naquele momento, os "Milton" "não viviam a etnicidade como um fator que os afastava de seus vizinhos seringueiros. Ao contrário, tratavam-se antes de seringueiros de origem indígena cuja trajetória de vida levou-os a lutar por uma demanda territorial comum, junto com outros seringueiros ${ }^{229}$.

Mais uma vez com suporte em PANTOJA (2011, pg. 124), compreende-se que,

Nessa visão, a crença num "parentesco de origem" justifica a auto percepção subjetiva daqueles que são diferentes dos demais, e serve tanto para auto-delimitar na microescala os Kuntanawa com uma memória genealógica local, como para substituir a categoria pejorativa de 'caboclos' pela de 'índios' unidos enquanto parentes com ancestrais precolombianos comuns.

Nos dois planos, a comunitarização é associada a novas estéticas corporais e a novos ritos coletivos. A "comunidade étnica" tem, portanto, uma clara e inegável dimensão política. Mas o que marca a "comunidade étnica" não são símbolos arbitrários, e sim habitus - disposições “difíceis de mudar" que são reconfiguradas ${ }^{230}$.

O caso dos Kuntanawa, que se diferenciam em um dado momento histórico, de população tradicional para indígena, configura, bom exemplo de comunidade formada por ressurgência étnica, tendo sempre estado em contato com outras comunidades que permanecem se autorreconhecendo tão somente como tradicionais. A demanda por uma terra própria, quando já possuem o amparo da Reserva Extrativista, demonstra o papel do elemento fundiário no processo de reconstrução cultural, bem ilustrando o trabalho

\footnotetext{
${ }^{229}$ Conforme veiculado em: http://pib.socioambiental.org/pt/povo/kuntanawa/2014 (consulta realizada em $02 / 12 / 2015)$.

${ }^{230}$ Ibidem, pg. 124.
} 
ora desenvolvido que relaciona o reconhecimento étnico às medidas de cunho social e econômico, dentre as quais a terra seria a mais marcante. 
MAPA DA SOBREPOSIÇÃO ENTRE A PRETENDIDA TERRA INDÍGENA KUNTANAWA E A RESERVA EXTRATIVISTA DO ALTO JURUÁ

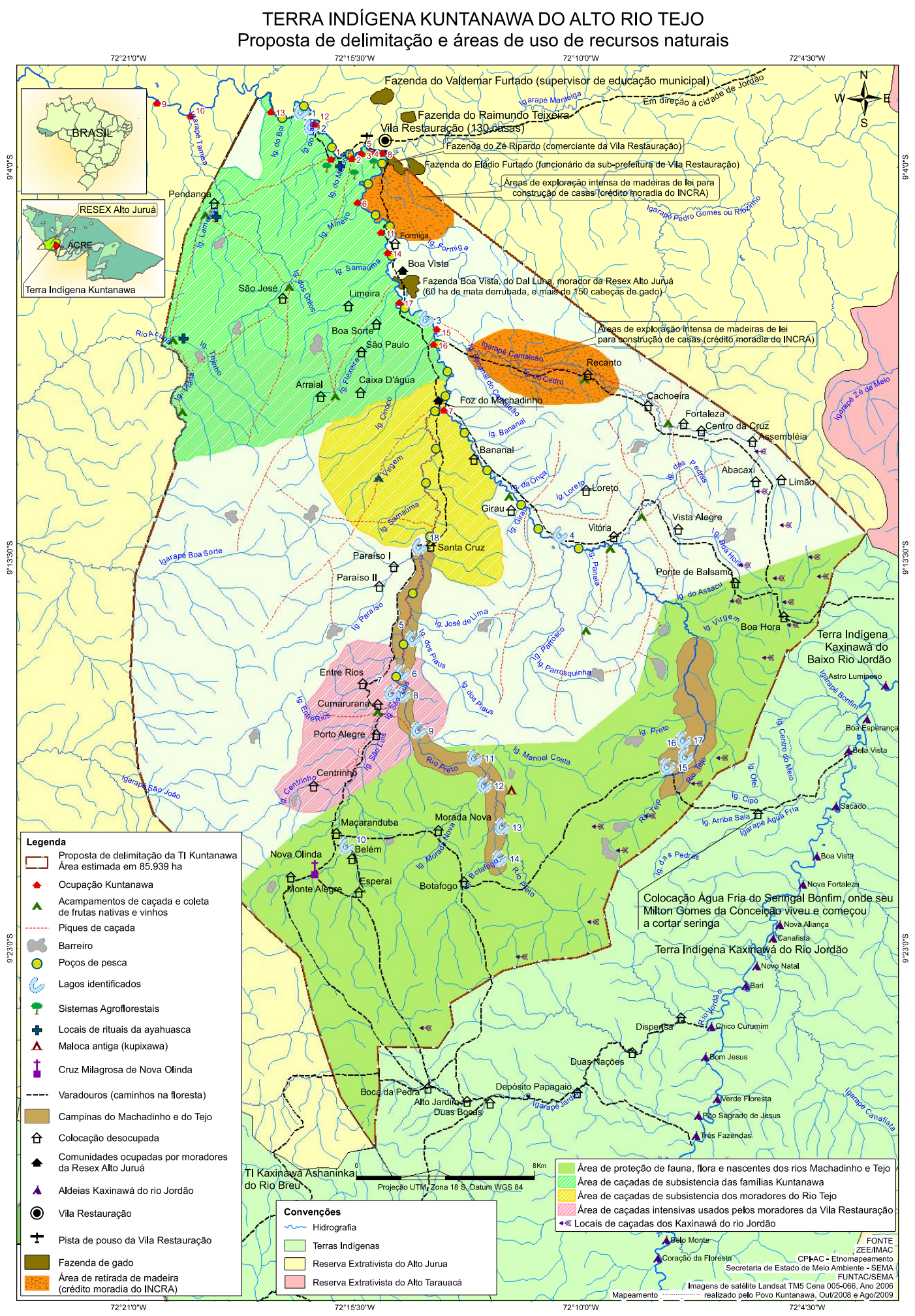

Fonte: Nova Cartografia Social da Amazônia. Os Kuntanawa do Rio Tejo. 2008. 


\section{Cap. 5.3. Reserva de Desenvolvimento Sustentável Mamirauá e Terra Indígena Porto Praia}

"todo amazonense é índio",231

Em 1996 o Estado do Amazônas decretou a transformação ${ }^{232}$ da então Estação Ecológica de Mamirauá ${ }^{233}$, na região do médio Solimões, em uma Reserva de Desenvolvimento Sustentável - RDS - de Mamirauá, com 1.124.000 hectares ${ }^{234}$. Com a transformação, reconhecia-se a existência de populações tradicionais em seu interior, admitindo-se sua permanência e exploração dos recursos florestais através de práticas sustentáveis.

Sabe-se hoje que a extensa Reserva se sobrepõe a pelo menos quatro terras indígenas: TI Jaquiri; TI Porto Praia; TI Uati Paraná; TI Acapuri de Cima, além de ser utilizada por integrantes das Terras Indígenas Cuiú-Cuiú; TI Marajaí; TI Mayoruna; TI Tupã Supé, vizinhas à Reserva.

Trata-se, destarte, de cenário complexo. Se de um lado as Terras Indígenas prestam-se à reprodução econômica e cultura dos grupos indígenas, as Reservas de Desenvolvimento Sustentável deveriam, em tese, beneficiar populações não-indígenas, não fazendo sentido a criação de RDSs sobre Terras Indígenas. A despeito disto, registra-se que quando da criação da Reserva algumas das Terras Indígenas citadas já se encontravam declaradas e demarcadas, como, por exemplo, a TI Jaquiri.

\footnotetext{
${ }^{231}$ SOUZA, Marina Oliveira e Souza. Passar para Indígena - na Reserva de Desenvolvimento Sustentável Amanã (AM). Dissertação de mestrado. UFMG. Belo Horizonte. 2011. Pg. 33

${ }^{232}$ Estado do Amazônas, Lei Estadual no 2411/1996, de 16 de julho de 1996.

233 Ao contrário das Reservas Extrativistas e Reservas de Desenvolvimento Sustentável, as Estações Ecológicas não permitem a ocupação humana.

${ }^{234}$ Se hoje, após a regulamentação perpetrada pela Lei 9985/00, as Reservas Extrativistas e Reservas de Desenvolvimento Sustentável guardam apenas poucas distinções, à época seu tratamento era idêntico, tão somente com variação na nomenclatura.
} 
Outras, entretanto, vieram a ser reconhecidas posteriormente, situação que particularmente nos interessa aqui. Dentre elas, mantemos o foco na Terra Indígena Porto Praia.

Conforme cita LIMA (2004, pg 540), “a área de Porto Praia era reconhecida como uma comunidade - denominação geral dos assentamentos humanos na região, associada a outro trabalho de promoção social desenvolvido pela Prelazia de Tefé e o Movimento Eclesial de Base (MEB) local” ${ }^{235}$.

Segundo relata, historicamente houve disputa na região sobre quais áreas seriam consideradas de preservação e quais seriam destinadas à exploração econômica, sobre o que rivalizavam as comunidades de Miraflor e de Porto Praia, em especial com relação ao Lago do Baú. Com a criação da Reserva, incentivou-se e legitimou-se a posição de Miraflor pela definição do Lago como área de preservação, vedando-se, por consequência, seu uso econômico. A posição foi revertida em seguida com a criação da Terra Indígena Porto Praia, quando esta comunidade retomou a autonomia para definição das regras sobre aquela área.

No que tange à proclamação da identidade indígena na região, recorda LIMA (2004, pg. 540):

No Médio Solimões, a presença de descendentes de Ticuna que desceram o Alto Solimões, principalmente após o período da borracha (em meados do século XX), é expressiva. Ao contrário dos Ticuna que vivem no Alto Solimões, no entanto, os Ticuna do Médio Solimões não expressam publicamente sua distinção étnica. $O$ fato de não guardarem os elementos diacríticos com que se diferenciam no Alto Solimões, como a língua e o ritual, reflete o terreno das ideologias étnicas e de dominação a que se refere Faulhaber em seu artigo. Dada esta constatação, é legítimo supor que tal campo político imponha aos Ticuna do Médio Solimões um conflito interno entre revelar ou ocultar a origem indígena, como sugere Reis. No contexto da demarcação de Porto Praia, a opção por assumir ou não a identidade Ticuna teve a conotação suplementar de condição necessária para ter acesso ao território em disputa. Ao mesmo tempo, a rejeição da origem indígena veio como conseqüência não necessariamente desejada ou consciente da opção por permanecer ligado à proposta de manejo ambiental. (grifei) ${ }^{236}$

O que se depreende, assim, é que a área que coincide com a TI é, historicamente, região de conflitos e disputas entre as comunidades pela utilização versus proteção de seus recursos.

\footnotetext{
${ }^{235}$ LIMA, Deborah de Magalhães. As sobreposições em Mamirauá e a necessidade de um novo pacto institucional. RICARDO, Fany (org.). Terras Indígenas \& Unidades de Conservação da natureza: o desafio das sobreposições. São Paulo: Instituto Socioambiental. 2004. Pg. 540.

${ }^{236}$ Ibidem.
} 
Na visão de REIS (2004, pg. 551)

"Esta situação me faz crer que a reivindicação de um território à parte pelos índios constituía uma alternativa para escapar aos confrontos, sobrepondo-se às tentativas de convivência e de gestão coletiva dos lagos empreendidas pela população local. Alguns agentes missionários diziam que a afirmação de etnia indígena por alguns grupos tem como interesse primeiro, assegurar a posse e a autonomia sobre um território através da sua delimitação". 237

Se correta a interpretação, pode-se dizer que a criação da Reserva, e em seguida da Terra Indígena, acompanham estratégias sucessivas na disputa pelo controle da área.

Nestas áreas de sobreposição, à semelhança do que vem ocorrendo na Reserva Extrativista Alto Juruá, passaram os tradicionais a se sentir coagidos, tendo em vista a possibilidade de terem que "abandonar suas posses ou de serem forçados, para continuar usufruindo do direito de habita-las, a assumir a identidade Ticuna. Os que o fizeram relataram, à época, terem sido apanhados de surpresa"238.

Isto somente se tornou possível porque, segundo REIS, “o índio da região de Mamirauá não expressa uma cultura distinta do ribeirinho, não possui um modo de vida diferente ou em oposição a ele"239.

Consoante afirma FAULHABER (2004, pg 554), os índios do Médio Solimões iniciaram sua história de mobilização em 1929, após lutas identitárias liderados pelos índios Miranha, com a demarcação em 1930 da Terra Indigena Miratu. Tais movimentos ressurgiriam na década de 1980. Fruto deste segundo momento, diversas outras Terras seriam reconhecidas, como a Jaquiri, Igarapé Grande, Barreira da Missão, Maraã Urubaxi, Paricá, Boá-Boá, Aparoris, Cuiú-cuiú, Japurá, entre outras ${ }^{240}$.

É neste segundo período que surge a demanda pela criação da Terra Indígena de Porto Praia, dos índios Ticunha, "tendo-se notícias que os Ticuna que ali viviam tinham

\footnotetext{
237 REIS, Marise. Terra Indígena Porto praia alternativa de posse de território e resistência à ordem socioambiental na RDS Mamirauá. In RICARDO, Fany (org.). Terras Indígenas \& Unidades de Conservação da natureza: o desafio das sobreposições. São Paulo: Instituto Socioambiental. 2004. Pg. 551.

${ }^{238}$ Ibidem, pg.

${ }^{239}$ Ibidem, pg.

240 FAUlHABER, Priscila. Participação indígena e preservação ambiental no Médio Solimões. In RICARDO, Fany (org.). Terras Indígenas \& Unidades de Conservação da natureza: o desafio das sobreposições. São Paulo: Instituto Socioambiental. 2004. Pg. 554.
} 
laços parentais de afinidade com os Miranha e Miratu, apesar de não terem sido visitadas por equipes de identificação". ${ }^{241}$

Debruçando-se sobre os acontecimentos, apresentou FAULHABER (2004, pg. 554) a seguinte interpretação fática:

O curso dos acontecimentos indica que as lutas sociais envolvem o reconhecimento de categorias sociais tais como: pequenos produtores, trabalhadores rurais, extratores, pescadores, o que não implica necessariamente o desaparecimento das identidades $e$ dos conflitos étnicos como ocorre com as reivindicações territoriais indígenas dentro da EEM. A despeito de um processo em curso de constituição de categorias genéricas e uniformizadoras tais como: caboclo ou "índio civilizado", registra-se a diferenciação étnica, referida a etnias específicas, que reivindicam um lugar diferenciado na sociedade, sem que isto signifique necessariamente o segregacionismo ${ }^{, 242}$.

Tal como nos demais casos citados, os relatos demonstram assimetrias de poder como pano de fundo da emergência identitária, atraindo para sua análise o conjunto teórico acima aportado.

\footnotetext{
${ }^{241}$ Ibidem, pg.

${ }^{242}$ Ibidem.
} 


\section{MAPA DA SOBREPOSIÇÃO ENTRE A RDS DE MAMIRAUÁ E A TERRA INDÍGENA DE PORTO PRAIA}

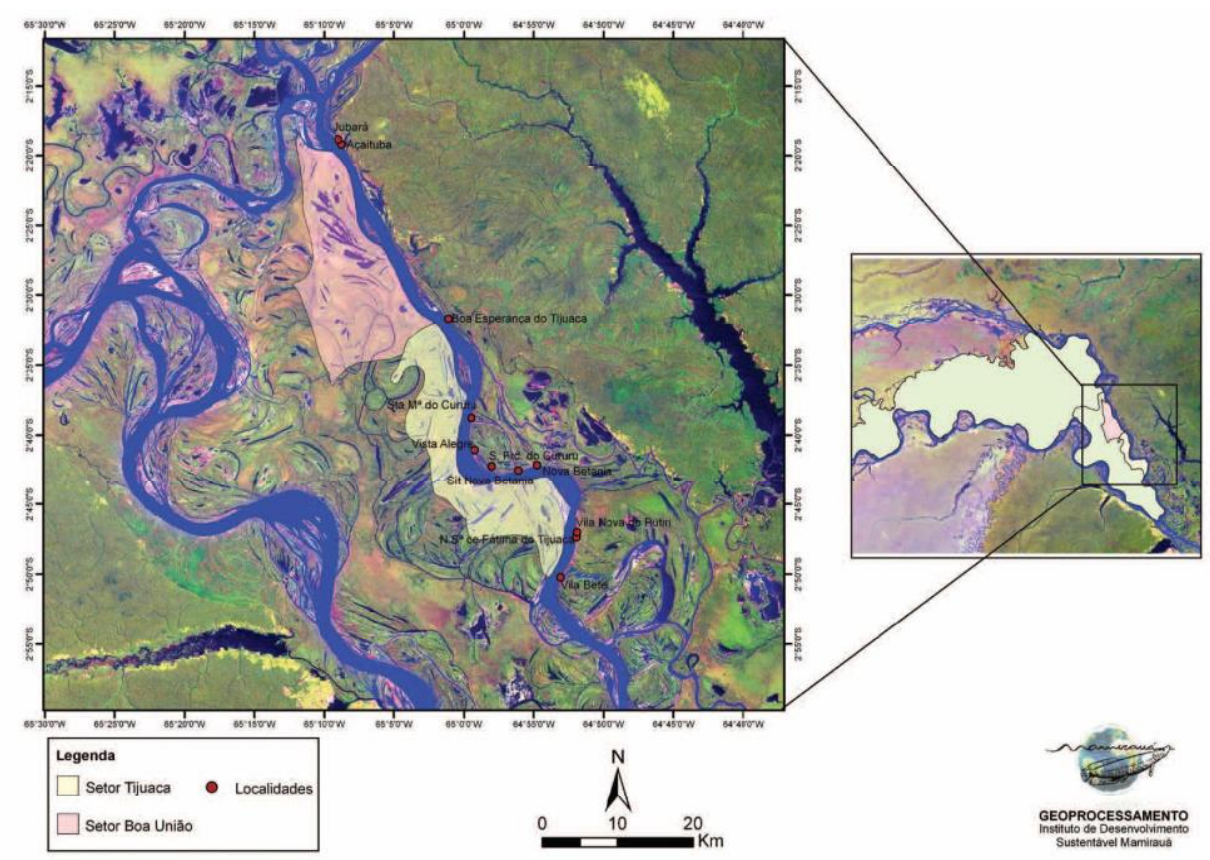

Figura 13 - Detalhamento da distribuição dos assentamentos dos Setores Tijuaca e Boa União (RDSM).

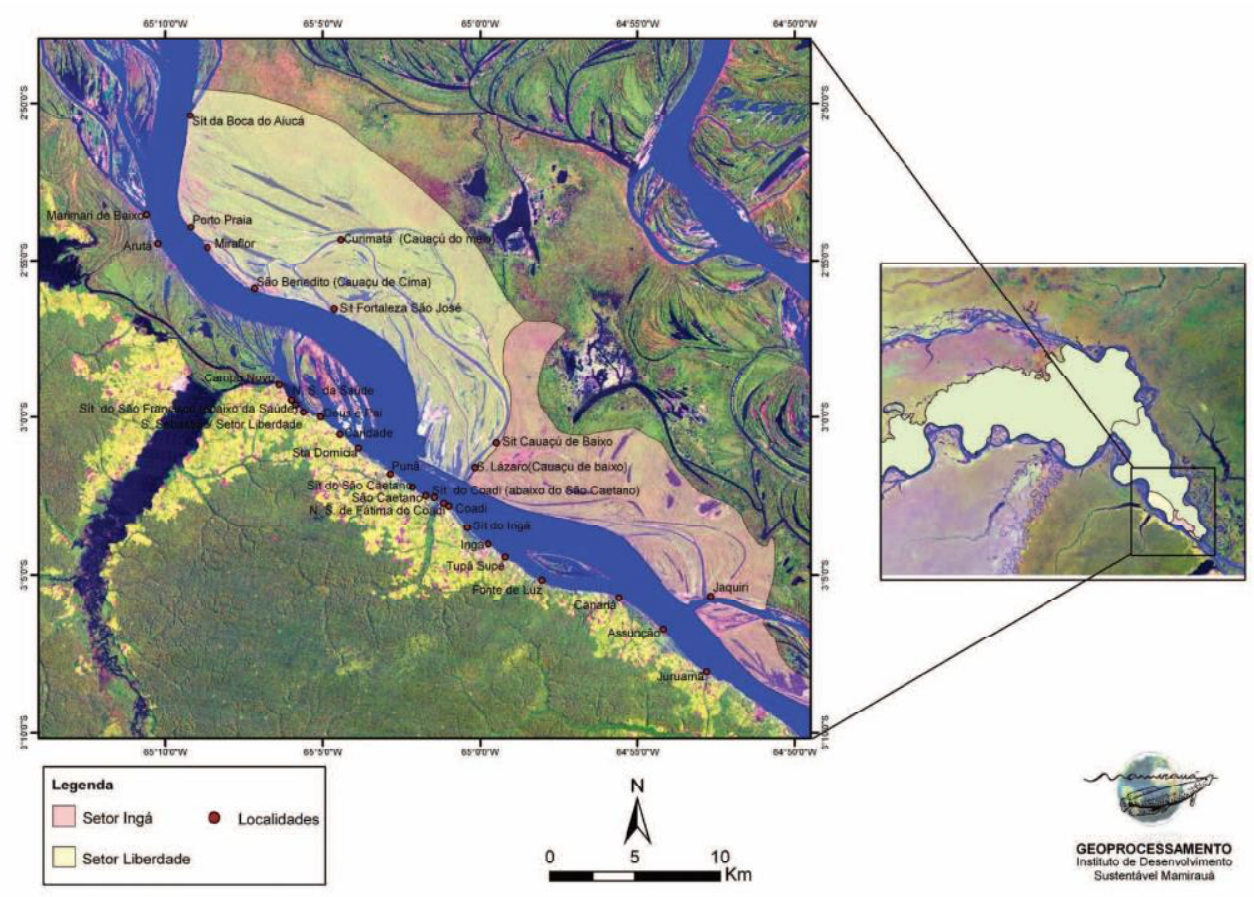

Figura 14 - Detalhamento da distribuição dos assentamentos dos Setores Ingá e Liberdade (RDSM).

FONTE: PLANO DE GESTÃO DA RDS DE MAMIRAUÁ. PG. 64. 


\section{Cap. 5.4. Floresta Nacional de Tapajós e os Taquara}

"Índio todo mundo criado aqui no interior é, mas tem gente que não quer o reconhecimento". ${ }^{243}$

A categoria de Unidade de Conservação denominada Floresta Nacional, embora tenha como objetivo básico "o uso múltiplo sustentável dos recursos florestais e a pesquisa científica, com ênfase em métodos para exploração sustentável de florestas nativas" 244 , admite hoje ${ }^{245}$ "a permanência de populações tradicionais que a habitam quando de sua criação" ${ }^{246}$, o que as tornam, nestes casos, muito semelhante às Reservas Extrativistas em suas porções ocupadas. É o caso da Floresta Nacional do Tapajós, criada em 1974, primeira da região amazônica, vinda ao mundo jurídico por meio do Decreto $n^{\circ} 73.684 / 74$, com dimensão total de 545 mil hectares no oeste do Pará.

O histórico de ocupação da região aponta grande afluxo populacional em 1830, com a chegada de grupos fugidos da Cabanagem, perseguidos em razão da origem

\footnotetext{
${ }^{243}$ SOUZA, Marina Oliveira e Souza. Passar para Indígena - na Reserva de Desenvolvimento Sustentável Amanã (AM). Dissertação de mestrado. UFMG. Belo Horizonte. 2011. Pg. 33

${ }^{244}$ Brasil. Lei 9985/00, de 18 de julho de 2000, art. 17.

${ }^{245}$ Conforme recorda ALLOGGIO, "Desde sua origem, o conceito de Flona foi voltado para a exploração de madeira, tentando incorporar idéias de manejo florestal que vinham acontecendo na Europa e na América do Norte. A diferença substancial é que nestes continentes praticamente não existem mais "populações tradicionais" nas florestas. Além disso, as florestas nos países do Norte são biomas com características bem diferentes das Florestas Tropicais, sendo a maioria florestas homogêneas, com poucas espécies e formadas para produção industrial de madeira. Ao importar este conceito, a idéia de Flona desconsiderou primeiramente a possibilidade de populações tradicionais morarem na floresta. Em sua concepção básica as Flonas são uma mistura de conservação e preservação com exploração industrial de madeira". (ALLOGGIO, Tibério. Trinta anos da Flona do Tapajós: avanços e retrocessos na integração entre conservação e participação social. In, RICARDO, Fany (org.). Terras Indígenas \& Unidades de Conservação da natureza: o desafio das sobreposições. São Paulo: Instituto Socioambiental. 2004. No ano de 2000, a Lei 9985 procurou adaptar a categoria à realidade brasileira, passando a permitir a permanência dos grupos humanos que já habitassem a Floresta Nacional no momento de sua criação. Até esta data, contudo, a antiga norma que regulamentava a categoria não o permitia, gerando entre seus moradores o temor de ter que dexiar a área.
}

${ }^{246}$ Brasil. Lei 9985/00, de 18 de julho de 2000, art. 17, parágrafo $2^{\circ}$. 
portuguesa ou da miscigenação ${ }^{247}$, dando origem às comunidades tanto da Floresta Nacional do Tapajós como da Reserva Extrativista Tapajós-Arapiuns.

Estudioso da região e de sua população, lembra o sociólogo VAZ FILHO (2004, pg. 572), recordando de suas primeiras visitas à região:

quando eu perguntava se eram índios, a resposta era sempre um sonoro "Não, somos civilizados". Ou no máximo alguém dizia "sou descendente de índios". Aparentemente não se via nenhuma tendência a um reavivamento étnico na comunidade. ${ }^{248}$

Também FRANCISCO (2004, pg. 575), então chefe da Floresta Nacional do Tapajós, afirma que até 1998 não havia qualquer tipo de referência à existência de remanescentes indígenas nos limites da Floresta Nacional do Tapajós e Reserva Extrativista Tapajós-Arapiuns, e que, "a partir dos estudos do frei Florêncio Almeida Vaz, 'História dos povos indígenas dos rios Tapajós e Arapiuns a partir da ocupação protuguesa', de 1999, iniciaram-se articulações de duas ONGs indignas e da CPT em Santarém junto ao Ministério Público Federal para a criação de TIs nas duas unidades."249

Segundo lembra VAZ FILHO (2004, pg. 576), nos primeiros contatos conheceu na comunidade Takuara um de seus mais antigos integrantes, chamado Laurelino, quem teve a oportunidade de entrevistar algumas vezes. Após a morte do antigo "curandeiro", foi procurado algumas vezes pelos moradores de Takuara, tendo fornecido-lhes fitas com gravações que fizera das entrevistas do predecessor. Os Takuara passariam, nos anos seguintes, longas horas ao redor do gravador escutando as gravações:

"Causou profunda reflexão em todos os trechos em que seu Laurelino diz que ele era índio, pois era filho de "puro índio", e que não se envergonhava daquilo. Ao contrário, sentia muito orgulho. Ele falava que ria das pessoas que tinham vergonha em dizer que eram indígenas. Com as palavras de seu Laurelino ecoando nas suas mentes, os filhos do falecido pajé decidiram se assumir como índios e buscar a demarcação das suas

\footnotetext{
${ }^{247}$ FRANCISCO, Angelo Lima. Conflito Fundiário na Floresta nacional do Tapajós, in, RICARDO, Fany (org.). Terras Indígenas \& Unidades de Conservação da natureza: o desafio das sobreposições. São Paulo: Instituto Socioambiental. 2004. Pg. 575.

${ }^{248}$ VAZ FILHO. As Comunidades Munduruku na Flona do Tapajós. RICARDO, Fany (org.). Terras Indígenas \& Unidades de Conservação da natureza: o desafio das sobreposições. São Paulo: Instituto Socioambiental. 2004. Pg. 572.

${ }^{249}$ FRANCISCO, Angelo Lima. Conflito Fundiário na Floresta nacional do Tapajós, in, RICARDO, Fany (org.). Terras Indígenas \& Unidades de Conservação da natureza: o desafio das sobreposições. São Paulo: Instituto Socioambiental. 2004. Pg. 575.
} 
terras. Consultaram os membros da comunidade e todos responderam que sim. Foi aí então que o filho mais velho de seu Laurelino procurou a Funai em Itaituba". ${ }^{250}$

Se a emergência identitária dos moradores de Takuna enquanto índios teve influência daquele peculiar fato, não há dúvidas, como ressalta o autor, que "a decisão de procurar a Funai deve ser compreendida dentro do contexto das lutas das comunidades em resistir na sua terra, desde que a Flona do Tapajós foi criada, em 1974, de forma autoritária pelo governo militar" 251 .

Acima se destacou que até o ano de 2000 não havia perspectiva - considerando a legislação em voga - dos moradores da Floresta Nacional de Tapajós de permanecerem nos seus limites. Exceto se reconhecidos como indígenas. A história acima compartilhada ocorreu no ano de 1998, ano da morte do Sr. Laurelino, anterior, assim, à mudança legal que se implementaria nos anos seguintes permitindo a permanência de tradicionais na Florseta. Naquela ocasião era vista com desconfiança a atuação do IBDF - e em seguida de seu suscessor, o IBAMA - na gestão da Floresta Nacional. Conforme explicita VAZ FILHO, "os moradores de Takuara eram os mais contrariados com a política do Ibama, e buscavam uma forma de se libertarem do seu domínio. A decisão pela via do movimento indígena foi tomada depois de muitas frustrações com a Flona e o Ibama."252

Os episódios que se seguiram revelariam um resgate dos símbolos indígenas, conforme narra o autor:

Pois bem, no dia 19 de dezembro chegamos a Takuara, com outros representantes de movimentos sociais, ONGs e do Conselho Indigenista Missionário (Cimi). Fomos recebidos na praia por senhores, jovens e crianças pintados de vermelho, adornados com cocares de penas de arara e muitos colares, bem próximos ao estereótipo do indígena no senso comum. Eu nunca havia visto aquelas pessoas assim. Tinham no semblante um ar de dignidade e grande contentamento." 253

Após algum tempo, aquele grupo passou a se intitular Munduruku, resgatando e recriando cada vez mais novos símbolos. Nos anos seguintes, novas comunidades

\footnotetext{
${ }^{250}$ VAZ FILHO. As Comunidades Munduruku na Flona do Tapajós. RICARDO, Fany (org.). Terras Indígenas \& Unidades de Conservação da natureza: o desafio das sobreposições. São Paulo: Instituto Socioambiental. 2004. pg. 576.

${ }^{251}$ Ibidem.

${ }^{252}$ VAZ FILHO. As Comunidades Munduruku na Flona do Tapajós. RICARDO, Fany (org.). Terras Indígenas \& Unidades de Conservação da natureza: o desafio das sobreposições. São Paulo: Instituto Socioambiental. 2004. Pg. 572.

${ }^{253}$ Ibidem
} 
indígenas demandaram o reconhecimento de suas identidades, a comunidade Taquara, Bragança e Marituba, ocasionando o temor dos "não-indígenas" com relação a seu futuro nas terras, gerando fortes conflitos na região.

Em 1999 o fato era noticiado pelo Instituto Socio Ambiental, nos seguintes termos:

\begin{abstract}
Moradores de Takuara querem ser reconhecidos como Munduruku As famílias da comunidade de Takuara, localizada na margem direita do rio Tapajós, município de Belterra, e inserida na área da Flona do Tapajós, solicitaram da Funai o reconhecimento de sua origem indígena Munduruku ou Tupinambarana. São aproximadamente 130 pessoas que vivem em terras de seus ancestrais, de quem herdaram os traços culturais.
\end{abstract}

A Funai determinou a execução de um estudo antropológico para confirmar a veracidade desta descoberta. "É um fato muito significativo, pois as famílias que mais de 70 anos não se diziam mais indígenas", afirmou o padre sociólogo Frei Florêncio Vaz, que vem dando apoio neste processo de reconhecimento.

Segundo ele, nessa situação há muitas outras comunidades, no rio Tapajós e Arapiuns. A solicitação deste reconhecimento foi feita por Raimundo Cruz, em atendimento a uma das últimas manifestações de desejo de seu pai, Laurelino Floriano Cruz, 88 anos, antes de sua morte, no ano de 1997. "Seu Laurelino" era muito conhecido na região por seus trabalhos de curandeiro. Ele garantia terem sido seus pais indígenas, de quem havia herdado os conhecimentos da pajelança. ${ }^{254}$

O fato intrigaria antropólogos, levando a estudiosos a afirmarem que "A "emergência" de comunidades indígenas na região do baixo rio Tapajós e rio Arapiuns transformou-se em um desafio de compreensão em vários sentidos" ${ }^{255}$. De fato, a ressurgência daquele grupo levaria a um intenso movimento de reconformação étnica na região, apontando VAZ FILHO que

cada vez mais outros grupos dessa região têm aparecem reivindicado o reconhecimento de identidade indígena. São índios mesmo? Por que "apareceram" só agora? Só estão querendo terra? Como serão as demarcações dentro da Resex e da Flona? Para muita gente seria melhor que esses índios não existissem, mas a verdade é que eles estão lá, organizados, orgulhosos da sua identidade étnica e exigindo suas terras demarcadas. ${ }^{256}$

Por exemplo, LIMA FRANCISCO, a respeito das recentes demandas por reconhecimento de identidade indígena no interior da Floresta Nacional do Tapajós afirmou:

" $\mathrm{Na}$ realidade o que está havendo é um longo trabalho de resgate cultural, perdido durante várias gerações, em função de vantagens prometidas pela Funai em oposição às

\footnotetext{
${ }^{254}$ Notícia veiculada pelo Notícias Socioambientais/ISA de 06/01/1999

${ }^{255}$ VAZ FILHO. As Comunidades Munduruku na Flona do Tapajós. RICARDO, Fany (org.). Terras Indígenas \& Unidades de Conservação da natureza: o desafio das sobreposições. São Paulo: Instituto Socioambiental. 2004. pg. 576.

${ }^{256}$ Ibidem.
} 
condições oferecidas pelo Ibama. As principais reivindicações são terras, saúde e apoio financeiro.

(...)

O direito do auto-reconhecimento, consagrado na Constituição de 1988, vem sendo utilizado mais recentemente com muita freqüência por populações tradicionais como forma de obter sua inclusão social. $\mathrm{O}$ grande pano de fundo é questão fundiária, o direito à posse da terra e usufruto de seus recursos naturais, patrimônio que populações tradicionais e indígenas, que têm vida marginal junto a sociedade, foram alijadas em função do modelo econômico historicamente implantado no Brasil. ${ }^{257}$

O caso, que compartilha com os demais o caráter de apresentação recente de pleito por reconhecimento indígena, é exemplo de comunidade tradicional que resgata antigos sinais diacríticos para transmidar seu status perante a sociedade para o de Indígena, daí demandando do Estado os direitos relativos a esta categoria. 
MAPA DAS COMUNIDADES DA FLORESTA NACIONAL DE TAPAJÓS

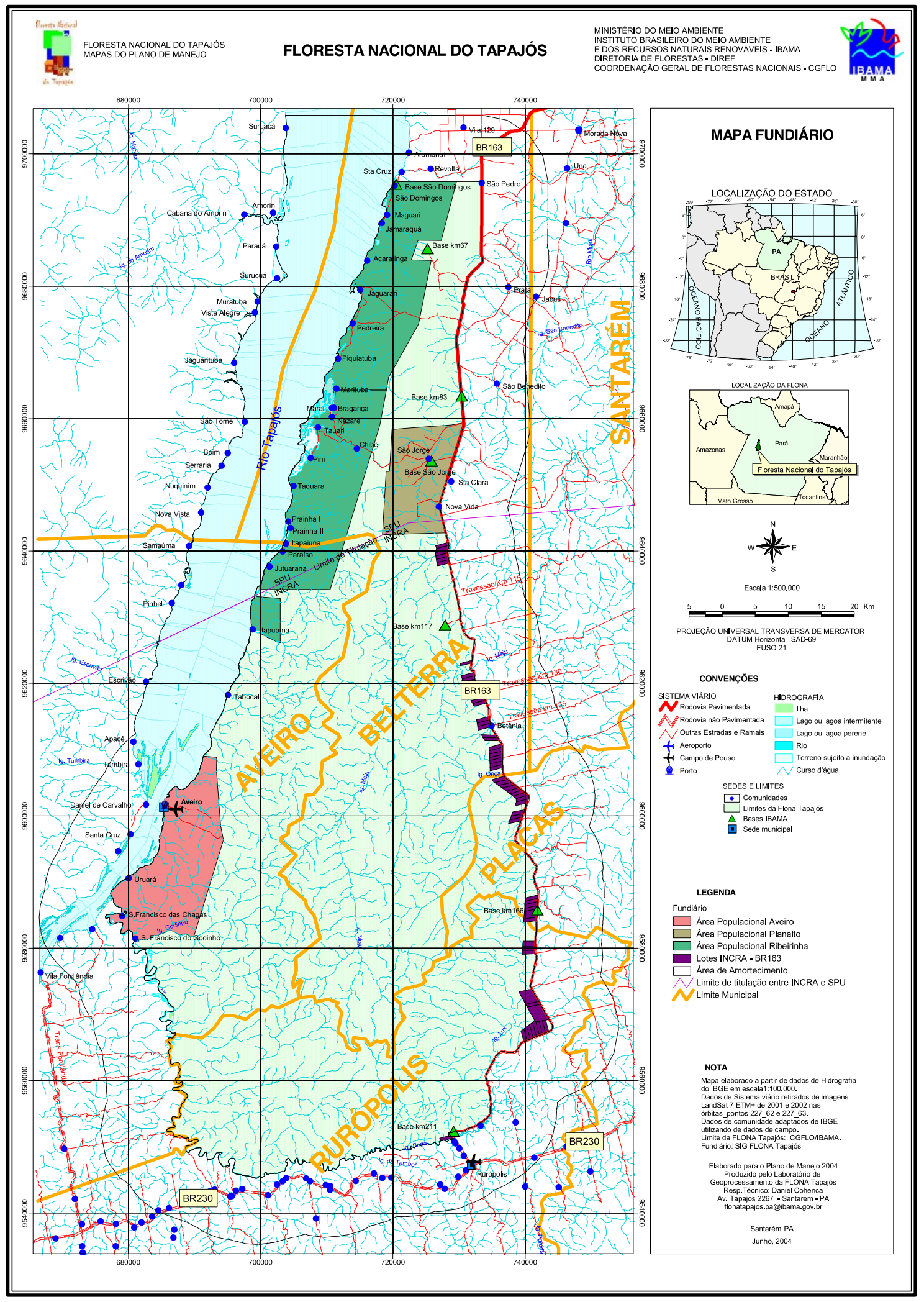

FONTE: PLANO DE MANEJO DA FLORESTA NACIONAL DE TAPAJÓS (2004) 


\title{
Cap. 5.5. Reserva de Desenvolvimento Sustentável Amanã e Comunidade Ebenézer
}

\begin{abstract}
"O que eu posso dizer do Coraci e do Putiri para te ajudar é que lá é índio mesmo. Eu mesmo tenho parente lá no Coraci, lá no São José. Eu conheço o S. Carmo do Ebenézer, é índio. Se tem uma coisa que eu posso fazer pra ajudar é falar que eles são índios mesmo, porque eu conheço eles e a gente é tudo parente ou conhecido. Aqui perto na Vila Alencar tem um tanto de parente meu, e nessas comunidades aqui perto também. Eu não sei porque eles não quiseram passar pra indígena ainda". ${ }^{258}$
\end{abstract}

A história das mobilizações indígenas no médio Solimões remonta a 1929, a partir de lutas dos povos Miranha que levariam ao reconhecimento pelo Serviço de Proteção aos Índios-SPI, em 1929, da aldeia Méria ${ }^{259}$. É na década de 1980, entretanto, que revigora-se o movimento indigenista na região, levando à demarcação de diversas Terras Indígenas, dentre elas a Miratu, Marajaí e Jaquiri, bem como a confirmação da própria Terra Indígena Méria, dentre outras.

Em meio a elas, visando a contenção das pressões antrópicas na região, e com o intuito de se prestigiar a aptidão que a relevante biodiversidade local confere para a realização de pesquisas científicas, seriam criadas, dentre outras, as Reservas de Desenvolvimento Sustentável de Mamirauáa ${ }^{260}$ e a de Amanã, como oásis no coração do fustigado Médio Solimões.

Obtendo - ainda que de forma insuficiente - a atenção do Estado, por meio de uma próxima atuação no que tange ao manejo dos recursos naturais, da proteção contra ameaças diversas, bem como tornando-se destinatárias de fundos ambientais e programas nacionais e internacionais, em pouco tempo as Unidades tornar-se-iam objeto de disputas pelos numerosos grupos que ali haviam fixado-se ao longo do tempo,

\footnotetext{
${ }^{258}$ SOUZA, Marina Oliveira e Souza. Passar para Indígena - na Reserva de Desenvolvimento Sustentável Amanã (AM). Dissertação de mestrado. UFMG. Belo Horizonte. 2011. Pg. 33

${ }^{259}$ Pelo procedimento à época, não se tratava, ainda, de Terra Indígena. FAULHABER, Priscila. Ambientalização dos conflitos, indigenismo e lutas sociais no Médio Solimões. As terras indígenas e o projeto Mamirauá/160. Revista Anthropológicas, vol. 22. 2011.pg. 104.

260 Esta, como acima visto, inicialmente como Estação Ecológica, posteriormente transformada em reserva extrativista.
} 
dentre comunidades indigenas, quilombolas, bem como populações tradicionais oriundas de antigas miscigenações entre imigrantes e locais.

Em que pese, entretanto as vantagens advindas da inserção nos limites das reservas, a submissão às regras limitadoras da Reserva passaria a ser vistas com ressalva por parte dos moradores que historicamente exploravam as possibilidades da região segundo seu conhecimento secular, o que repercutiria na forma de movimentos étnicos com diferentes feições na região. FAULHABER (2011, pg. 104) recorda que

\begin{abstract}
A decretação da EEM [Estação Ecológica de Mamirauá] teve como resposta uma reafirmação étnica, que para os indígenas estava associada à garantia do direito de não respeitar as bandeiras ecológicas (...). Mas à medida que tomaram conhecimento das atribuições da FUNAI e de suas relações com a política ambiental, passaram a buscar boas relações com as agências da sociedade envolvente e se reconhecer no seu território agora identificado e delimitado conforme os procedimentos institucionais." ${ }^{261}$
\end{abstract}

De outro lado, como aponta a mesma autora, (2004, pg. 554), da parte da Administração da Reserva, "a mobilização étnica, associada à reivindicação territorial, era considerada 'perigosa' pelos representantes do Projeto Mamirauá"262.

É neste contexto que se situa o caso da vila Ebenézer, uma comunidade evangélica situada em um dos afluentes do rio Japurá, o rio Coraci, inserida na Reserva de Desenvolvimento Sustentável de Amanã, que, utilizando as palavras de SOUZA (2011, pg. 01), "passou para indígena na última década, se autorreconhecendo como Miranha" ${ }^{263}$.

A mesma autora recorda que a ocupação do local onde hoje se situa a comunidade Ebenézer ocorreu entre as décadas de 1920 e 1930, em função das atividades comerciais proporcionadas pela extração da seringa e da castanha. É no final da década de 1970 e início de 1980, entretanto, que se funda a atual Ebenézer, reunindo famílias que para ali se dirigiriam constituindo laços de parentesco e afinidade cultural, especialmente congregados pela religião evangélica, em um meio onde professam as

261 FAULHABER, Priscila. Ambientalização dos conflitos, indigenismo e lutas sociais no Médio Solimões. As terras indígenas e o projeto Mamirauá/160. Revista Anthropológicas, vol. 22. 2011. pg. 104.

262 FAULHABER, Priscila. Participação indígena e preservação ambiental no Médio Solimões. In RICARDO, Fany (org.). Terras Indígenas \& Unidades de Conservação da natureza: o desafio das sobreposições. São Paulo: Instituto Socioambiental. 2004. Pg. 554.

${ }^{263}$ SOUZA, Marina Oliveira e Souza. Passar para Indígena - na Reserva de Desenvolvimento Sustentável Amanã (AM). Dissertação de mestrado. UFMG. Belo Horizonte. 2011. Pg. 33. Pg. 01. 
demais comunidades locais a religião católica. A pequena vila possuía, até 2011,13 casas apenas, abrigando 84 pessoas. Na descrição da estudiosa, seria ela constituída de,

“onze casas em terra enfileiradas no estilo palafita na várzea, duas casas flutuantes, uma escola mantida pela Prefeitura de Maraã, uma filial da Congregação da igreja Cristã Evangélica de Alvarães, um campo de futebol, uma cozinha de forno, um motor de luz comunitario e uma placa de captação solar, usada para enchar uma caixa d'água de 5000 litros descrevem as edificações de Ebenézer. A paisagem no entorno da comunidade, no entanto, rapidamente se modifica com as variações sazonais (enchente/seca) e desbarrancamento do leito do rio Coraci e crescimento de ilhas o que conforma um cenário ambiental de grandes transformações."264

Em ambas as Reservas - Mamirauá e Amanã -, sensíveis desgastes ocorreriam entre as populações usuárias de suas áreas de várzea, onde o nível da água varia até 12 metros ao ano, ficando os limites das porções individuais sujeitos a grande variação, de acordo com o regime das cheias. Durante os períodos de seca as áreas são utilizadas para agricultura, enquanto nos períodos de cheia

\begin{abstract}
“além de ser um período de escassez de pesca, o avanço da água propicia a extração da madeira de lei, gerando disputas entre os próprios membros das comunidades que, de acordo com a demanda de seus grupos de referencia, são levados a permitir a pesca predatória e a extração clandestina de madeira, muitas vezes em trocas pouco compensatórias".
\end{abstract}

A variabilidade sazonal acentuada é, assim, fator complexificador da rotina das populações ali presentes.

Especialmente para a comunidade de Ebenézer, a acentuada distância das cidades mais próximas desestimula a venda da produção, inviabilizando sobretudo a comercialização do pescado, em razão da complexa logística de refrigeração que a torna pouco competitiva no mercado.

Neste cenário marcado pela precariedade e abandono é que a expectativa de avanços, nos moldes de outras comunidades que haviam se reconhecido como indígenas, levaria aquela pequena vila a também pleitear o seu reconhecimento. É o que afirma SOUZA (2011,pg. 103):

A experiência e o contato com aldeias e áreas homologadas no médio Solimões, mais do que uma ideia abstrata de direitos diferenciados, foi o que apareceu em Ebenézer, Putiri e NS de Fátima como motivação para passar para indígena. Moradores do interior, de comunidades indígenas ou não, tecem laços de amizade, vizinhança e parentesco com as aldeias, o que cria impressões de proximidade entre eles.

$(\ldots)$

\footnotetext{
${ }^{264}$ SOUZA, Marina Oliveira e Souza. Passar para Indígena - na Reserva de Desenvolvimento Sustentável Amanã (AM). Dissertação de mestrado. UFMG. Belo Horizonte. 2011. Pg. 33. Pg. 101.
} 
O exemplo das terras demarcadas indica que também no interior é possível ter acesso ao que eles julgam como uma vida melhor. Nas três comunidades se ouvia o status de pólo indígena das áreas já demarcadas, tanto de saúde como de educação. Faziam menção também à presença de um rádio e de telefone público instalado. A condição de pólo de algumas aldeias demarcadas da região do médio Solimões muitas vezes apareceu como explicação dos moradores das comunidades indígenas em que estive para passar para indígena". ${ }^{265}$

Na sequência dos fatos, em 1999, em pré-levantamento atropológico realizado pela Funai, a comunidade identifica-se como Miranha, encaminhando no começo de 2000 pedido de reconhecimento como povo indígena. Conforme esclarece SOUZA (2011, pg. 19), em denso estudo realizado sobre aquela comunidade, "a escolha da etnia Miranha foi feita em referência à mãe e esposa de Carmo", uma das primeiras moradoras da vila"266.

O anúncio, levaria a diversos conflitos na região, em especial com a Vila Nova, comunidade próxima, em razão de disputas por áreas de roça; e entre Ebenézer e o setor Coraci, formado pelas comunidades: Vila Nova, Iracema, São Paulo, São João do Ipeacaçu, Nova Canaã e Matuzalém, conflitos por áreas de lagos ${ }^{267}$.

Em 2002 implementou-se na Reserva de Desenvolvimento Sustentável o manejo do pirarucu. A comunidade Ebenézer participou do manejo até o ano de 2006, tendo interrompido sua participação após acirramento com as comunidades do setor Coraci e de Vila nova, em razão do autorreconhecimento como indígena e as sobreposições que uma possivel Terra Indígena gerariam sobre estas, deixando Ebenézer em situação ainda mais precária.

Após uma tentativa frustrada de manejarem o pirarucu de forma isolada, acabaram alguns moradores de Ebenézer por tentar novamente ingressar no Plano oficial da Reserva, o que exigiria, por sua vez, a aceitação do setor Coraci.

Como alternativa, os moradores de Ebenézer passariam a se dirigir especialmente à Funai solicitando aposentadorias, auxílio-maternidade e assistência à

\footnotetext{
${ }^{265}$ SOUZA, Marina Oliveira e Souza. Passar para Indígena - na Reserva de Desenvolvimento Sustentável Amanã (AM). Dissertação de mestrado. UFMG. Belo Horizonte. 2011. Pg. 33. Pg. 103.

${ }^{266}$ SOUZA, Marina Oliveira e Souza. Passar para Indígena - na Reserva de Desenvolvimento Sustentável Amanã (AM). Dissertação de mestrado. UFMG. Belo Horizonte. 2011. Pg. 33. Pg. 19.

${ }^{267}$ Ibidem, pg. 20.
} 
saúde, concentrando seus pleitos em face da autarquia indigenista na busca de serviços públicos em geral, reforçando a identidade indígena ${ }^{268}$.

Na leitura da mesma pesquisadora,

"Diferentemente das comunidades do setor Coraci que vêm nos manejos, produção agrícola e autonomia da associação uma forma de melhorar a qualidade de vida pela geração de renda, alguns moradores de Ebenézer associam essas melhoreias aos órgãos públicos, como a Funai, à Prefeitura de Maraã. São lógicas diferentes para alcançar objetivos parecidos e melhores condições no interior. ${ }^{269}$

Este é o sentido do movimento indígena na região, que "aparece inicialmente relacionado ao interesse comum das aldeias pela autonomia, demarcação das áreas, construção de escolas e barco comunitário para comercializar a própria produção"270, e que podem ser resumidos pelo relato contido em Carta de comunitário de Itaboca:

A briga mais forte foi por causa que a minha família não aceitou se declarar como índio. Então eles se achavam como índios e os direitos só eram pra eles e não eram pra nós. Nós como extrativistas associados à Associação do Auati-Paraná, eles resolveram sair do quadro de sócios pra ser índio. Quer dizer eles tem mais direito do que nós e só vamos ter direito se a gente se declarar como índio, senão a gente ia ser excluído. Mas não, a gente também tinha direito, sendo índio ou não sendo a gente também tinha direito. Até que a terra fosse demarcada a gente garantia o direito também. Aí começou a briga. Chegou até a ter quase morte entre famílias, foi uma coisa muito séria. E só não teve briga porque na época eu era coordenador e eu fui em cima pra evitar ${ }^{271}$.

A descrição do histórico da vila Ebenézer ressalta o "jogo político", de estratégias e embates que envolvem o autorreconhecimento étnico, evidenciando, assim, que

O passar para indígena em Ebenézer envolve um histórico de diferenciação: primeiro religiosa, quando passam a ser evangélicos no meio de comunidades católicas; depois econômica, quando enfatizam a pesca como atividade preferencial em um setor que privilegia a agricultura e, por último, pela diferenciação étnica. Os moradores legitimam o pedido de reconhecimento indígena pela descendência, reconhecimento do tuxaua no movimento indígena de alcance regional e redes de amizade e parentesco com os parentes (indígenas), termo usado para fazer referência aos moradores de aldeias ou comunidades indígenas da região, como é o caso de moradores da comunidade indígena Nova Canaã e TI Cuiú-Cuiú. ${ }^{272}$

\footnotetext{
268 Ibidem.

${ }^{269}$ Ibidem, pg. 113.

${ }^{270}$ Ibidem, pg. 82

${ }^{271}$ Missiva do presidente da AAPA e comunitário de Itaboca. SILVA, Katiane. Conscientização, tradição e desenvolvimento. Intratextos, Rio de Janeiro, 6(1): 2014, pg. 14.

${ }^{272}$ SOUZA, Marina Oliveira e Souza. Passar para Indígena - na Reserva de Desenvolvimento Sustentável Amanã (AM). Dissertação de mestrado. UFMG. Belo Horizonte. 2011. Pg. 33. Pg. 119.
} 
MAPA DAS TERRAS INDÍGENAS DEMARCADAS E COMUNIDADES EM PROCESSO DE RECONHECIMENTO INDÍGENA NA REGIÃO DO MÉDIO SOLIMÕES.

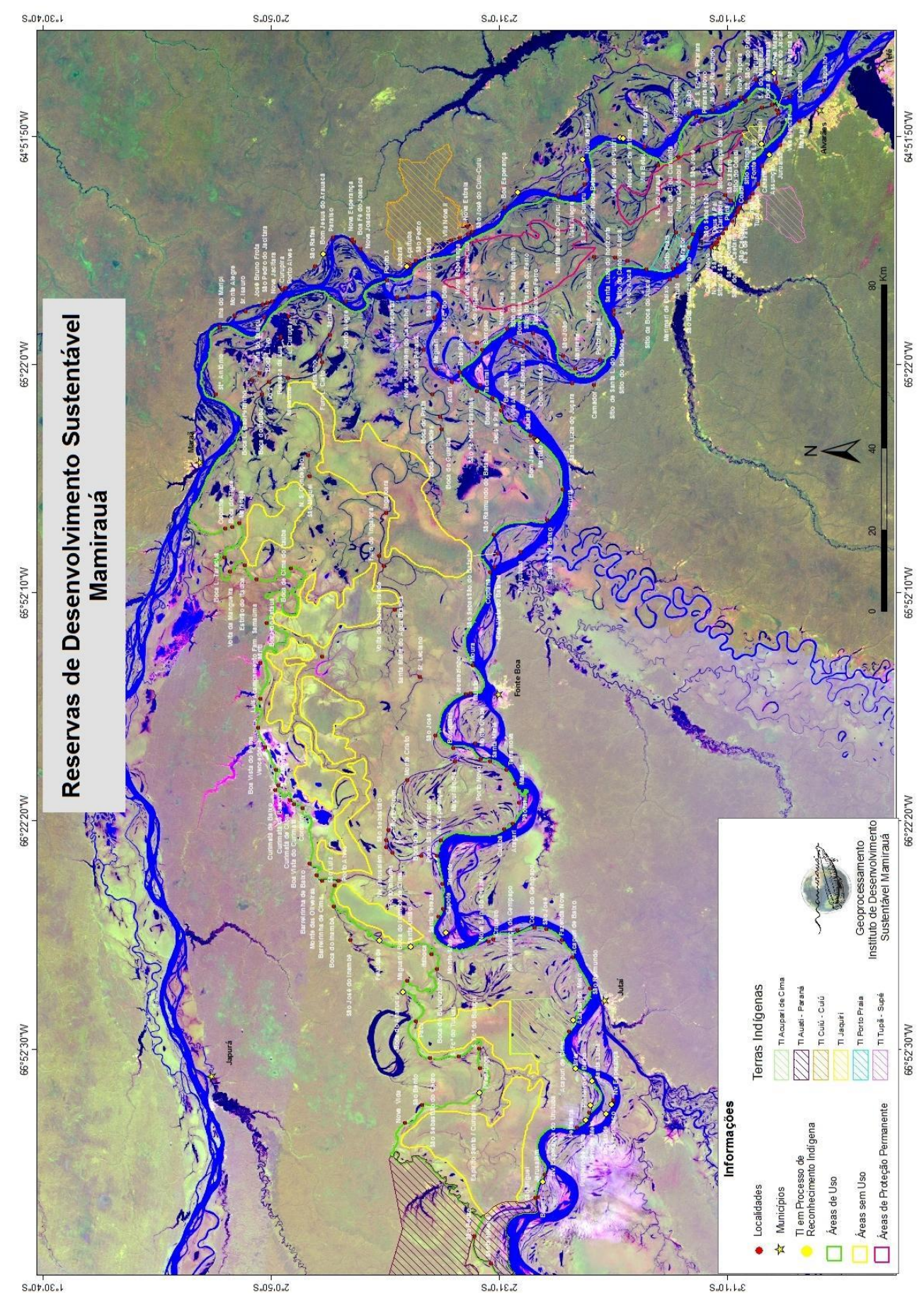

FONTE: SOUZA, Marina Oliveira e Souza. Passar para Indígena - na Reserva de Desenvolvimento Sustentável Amanã (AM). Dissertação de mestrado. UFMG. Belo Horizonte. 2011. 


\title{
Cap. 6. Conclusões
}

Na data de 21 de outubro de 2015, durante reunião da Comissão Especial da Câmara dos Deputados instituída para debater a Proposta de Emenda Constitucional $\mathrm{n}^{\circ}$ $215 / 00^{273}$, que contava com a presença de expressivo número de representantes de comunidades indígenas, afirmou o Deputado Valdir Colatto, em tom repreendedor às manifestações vindas das galerias: "tem alguns índios legítimos aqui presente, mas tem genéricos também”.

A polêmica frase, que provocou a reação de diversas entidades indigenistas, trouxe à mídia debate que já se mostra presente no meio acadêmico nos últimos séculos, acerca das identidades de comunidades étnicas, seus processos de reorganização social e cultural, bem como de reconstrução identitária.

A expressão índio genérico fora utilizada por Darcy Ribeiro em 1970 ao descrever a transfiguração do 'índio tribal' pelo contato com a sociedade, antes ressaltando a condição de vítima daqueles indivíduos diante do processo agressivo de devastação cultural em marcha, do que no sentido empregado pelo parlamentar, que apontava para um oportunismo dos indivíduos, como impostores da condição de silvícola ali sustentada ${ }^{274}$. Na ocasião afirmava o teórico,

\begin{abstract}
"Observe-se bem que, embora tratando-se, de certa forma, do passo da condição de selvagem à de civilizado, não se trata aqui da passagem da condição de índios à de nãoíndios, porque isto não sucedeu em nenhum caso do qual se tenha evidência. $O$ passo que efetivamente ocorre é entre a situação de índios específicos, armados de seus atributos culturais, sociais, psíquicos e a de índios genéricos, despidos deles, para se integrar à sociedade nacional como grupos marginalizados, vivendo o drama de sua entrega à civilização, de sua doida adesão a ela, mil vezes tentada e mil vezes rechaçada e de sua própria e simultânea resistência à transfiguração étnica",275
\end{abstract}

\footnotetext{
273 O texto integral da proposta pode ser visualizado em: http://www2.camara.leg.br/atividadelegislativa/comissoes/comissoes-temporarias/especiais/55a-legislatura/pec-215-00-demarcacao-de-terrasindigenas (Consulta realizada em 25/11/2015).

${ }^{274}$ SOUZA, Marina Oliveira e Souza. Passar para Indígena - na Reserva de Desenvolvimento Sustentável Amanã (AM). Dissertação de mestrado. UFMG. Belo Horizonte. 2011. Pg. 33. Pg. 116.

275 RIBEIRO, 1976, p.478-479 apud SOUZA, Marina Oliveira e Souza. Passar para Indígena - na Reserva de Desenvolvimento Sustentável Amanã (AM). Dissertação de mestrado. UFMG. Belo Horizonte. 2011. Pg. 33. Pg. 116.
} 
Em que pese a importância dada ao tema pela literatura científica - o que se denota da atenção conferida a ele por grandes pensadores mundiais, como Marx, Weber, Hobsbawn, dentre outros citados neste trabalho -, expressões com a que agitou o Congresso no último mês demonstram o estágio preliminar em que tal conhecimento encontra-se difundido entre o senso comum, contaminando as mais altas esferas tomadoras de decisão no país.

Fenômenos abordados ao longo do presente trabalho, como o da reorganização cultural de grupos étnicos, transformações identitárias, ressurgência, acabam, assim, transvestindo-se das mais superficiais roupagens do preconceito, impondo aos grupos vulneráveis a reprodução das mazelas cotidianas que os assolam desde o início da colonização.

Rejeitando-se, neste sentido, toda forma de redução, não se pode ignorar que a ocorrência de novos pleitos por Terras Indígenas advindos de comunidades tradicionais já beneficiárias de Unidades de Conservação, modelos vocacionados a conferir-lhes proteção e meios para desenvolvimento econômico, social e cultural, coincide com o enfraquecimento da Reservas Extrativistas vis-a-vis às Terras Indígenas.

Por meio do presente trabalho buscou-se, assim, revisar a bilbiografia que historicamente tratou do tema, com foco, sobretudo, em demonstrar como aquelas teorias explicam complexos eventos como os acima abordados, desmistificando e justificando-os.

A eleição de casos concretos teve, neste escopo, não o sentido de colocá-los à prova, testando-os sob o prisma da bibliografia compilada, o que revelar-se-ia tarefa demasiadamente ousada para os objetivos e limites de uma dissertação de mestrado; senão, dado o tratamento minucioso já realizado sobre os casos por renomados especialistas, teve o objetivo de aproveitar os elementos fáticos já descritos, ilustrando o marco teórico trazido.

Mais do que isto, a descrição daqueles casos confere atualidade e proximidade à problemática, especialmente aproximando a doutrina, em grande parte produzida internacionalmente, d peculiar realidade brasileira, e, sobretudo, do multicultural e pluriétinico cenário que caracteriza a região amazônica. 
Neste sentido é que a leitura mais acurada dos casos veio revelar que, de fato, aquelas comunidades não se viam como indígena até passado recente, conforme assim informavam aos órgãos públicos à época, sendo beneficiárias de Reservas Extrativistas, Unidades especificamente voltadas para as populações tradicionais. Os pedidos ulteriores de reconhecimento perante o órgão público coincidiram, em todos eles, com situações conflituosas e de privação relativa, que se apaziguariam ou minimizariam com tal transformação identitária.

Tal constatação encontra explicação teórica nas teorias acima apresentadas, sobressaindo, com efeito, o papel da atuação do Estado na reorganização cultural das populações tradicionais, especialmente por meio da dicotomização dos grupos em categorias estanques, ao que se soma a implementação de políticas públicas exclusivas e diferenciadas para cada uma delas.

Tal relação - autorreconhecimento recente de populações tradicionais como indígenas e discrepância do regime jurídico de uma e outra categoria - mostra-se explicável à luz do construtivismo, e, mais especificamente, por teorias como a da privação relativa, aqui citada, chamando a atenção dos formuladores de políticas públicas para os impactos sociais destas medidas sobre as identidades de seus destinatários.

O percurso traçado ao longo do presente trabalho vem sustentar, ao contrário do que denota a frase proferida pelo parlamentar, supracitada, que a reconstrução das identidades levando em conta elementos fáticos circunstanciais não implica, dessarte, em falsidade, senão constitui natural movimento identitário em face de meio marcado por assimetrias. Afinal, conforme afirma SOUSA (1999, pg. 122),

A etnicidade constitui uma estratégia. Quer dizer, representa o produto de uma eleição consciente de grupos de pessoas para alcançar certos objetivos sociais. Sem negar completamente o seu envasamento tradicional, somático, linguístico, etnocultural, parece preferível não apenas pluralizar a noção, mas passar a investigá-la no campo das estratégias sociais, culturais e simbólicas que afirmam agrupamentos sociais com as suas especializações, da cultura material aos festivais religiosos, dos poderes ao sistema de valores. $^{276}$.

\footnotetext{
276 SOUSA, Ivo Carneiro de. Etnicidade e Nacionalismo: Uma proposta de quadro teórico. Africana Studia. N. 1, 1999. Portugal. Pg. 122.
} 
Neste cenário, o estudo revela a importância de que as demandas de cunho econômico e social daquelas populações sejam satisfeitas sem que para isto tenham que se reenquadrar em categorias diversas. Não há, assim, crítica propriamente à atuação afirmativa do Estado, atuando de forma positiva a atender as necessidades das populações. As distorções, ao contrário, existiriam no momento em que tal atuação estivesse vinculada à necessidade de autorreconhecimento em categorias estanques.

Diz respeito assim, a questão, à necessidade de garantir o Estado a reprodução cultural de suas populações étnicas, sem forçar que as mesmas tenham que abandonar suas culturas, reconstruíndo suas identidades, de modo a obter a acesso a meios de sobrevivência.

Paralelamente aos recentes pedidos de reconhecimento como indígenas, extremada reação, fruto de nítida desinformação, passa a emergir no seio da sociedade, dificuldando o gozo de direitos já consagrados e conduzindo a profundos retrocessos, em um movimento pendular de ampliação e redução de direitos e oportunidades que o histórico acima mencionado vem confirmar.

Maior retrato deste cenário é o avanço para a discussão em Plenário da acima citada PEC 215/007 , que modifica diversos dispositivos da Constituição Federal, em suma complexificando e limitando a criação de novas terras indígenas, além de, dentre outros efeitos, impor a submissão ao Congresso Nacional do processo demarcatório, alterando o atual cenário em que o Poder Público meramente declara ditas Terras sobre áreas tradicionalmente ocupadas.

Adotando-se os pilares teóricos acima reunidos, não restam dúvidas de que tal alteração institucional, caso acolhida, gerará também efeitos sobre as identidades étnicas dos povos indígenas, tal qual hoje se verifica, em sentido analogamente oposto, em relação às populações tradicionais, justificando uma vez mais o título eleito para o presente trabalho, que destaca não a legitimidade ou falsidade dos recentes pleitos por reconhecimento, senão o papel das políticas públicas sobre as identidades coletivas.

\footnotetext{
277 O texto da proposta pode ser consultado no seguinte link, diretamente da página da Câmara dos Deputados: $\quad$ http://www2.camara.leg.br/atividade-legislativa/comissoes/comissoestemporarias/especiais/55a-legislatura/pec-215-00-demarcacao-de-terras-indigenas (Consulta realizada em 25/11/2015).
} 
Não por outra razão, afirma MAYBURY-LEWIS (2003) que "são os estados que ditam as regras de nossas vidas e, sobretudo, que dão forma às nossas identidades, tanto coletivas como individuais" 278 .

O percurso traçado pautou-se, assim, primeiramente por revelar o histórico das populações tradicionais em sua luta por terras e direitos próprios, à semelhança das categorias indígena e quilombola então já contempladas. Deste resgate, a associação com movimentos ambientalistas em voga à época seria determinante para a inserção de suas terras no contexto do conservadorismo, limitando a liberdade das populações na gestão e manejo das áreas quando comparadas ao paradigma representado pelas Terras Indígenas. Para fins de delimitação, também o histórico da afirmação dos indígenas foi trazido à tona, demonstrando a ampla luta pela conquista dos direitos hoje assegurados pelo ordenamento jurídico.

Na sequência, comparou-se objetivamente os dois regimes, confirmando-se a vantajosidade das Terras Indígenas em face das Reservas Extrativistas.

No campo teórico, tratou-se das identidades étnicas, seus elementos básicos de compreensão e sua utilização pelas ciências, antes de se adentrar nas teorias que confrontam suas qualidades, contrapondo sua essencialidade à circunstancialidade.

Estas seriam o insumo para o estudo da evolução do tratamento pelo Estado brasileiro da questão étnica, então brevemente arrolado.

Em complemento, expôs-se a teoria da privação relativa, que ressalta as consequências das desigualdades na mobilização política das identidades étnicas, bem como o debate existente sobre os remédios à disposição do Estado para combater tais desigualdades.

Seguindo este fluxo, fez-se na organização dos capítulos um contraponto entre as desigualdades notadas no sistema, a atuação do Estado, as consequências advindas das desigualdades e a dificuldade ínsita à definição de políticas públicas a grupos carentes tanto de reconhecimento como de redistribuição econômica.

\footnotetext{
${ }^{278}$ MAYBURY-LEWIS, David. Identidade Étnica em Estados Pluriculturais. In: Scott, Parry \& Zarur, George (org) Identidade, Fragmentação e Diversidade na América Latina. Recife. Ed. Universitária. 2003.
} 
Por fim, após incursão realizada sobre os casos particulares, finalizo com referência a REZENDE (pg. 25) que bem resume, no excerto abaixo, as conclusões do persente trabalho, que aqui tomo de empréstimo:

"É possível separar a percepção dos moradores sobre suas condições de vida em dois grupos: a percepção sobre o acesso a direitos básicos da cidadania (saúde, educação, comunicação, transporte, emprego - no sentido de terem mercado para seus produtos saneamento básico e outros benefícios sociais), e a percepção sobre a gestão territorial e ambiental. De modo geral, nos casos de demandas por sobreposições, os moradores demonstram insatisfação tanto com o acesso a direitos básicos como com a gestão territorial. Como citado acima, o Protuto I atentou para uma deficiência generalizada na prestação de serviços sociais aos moradores de Reservas Extrativistas. Este é, sem dúvidas, um dos principais problemas para a gestão de conflitos territoriais originados por demandas por sobreposições. A diferenciação entre direitos de indígenas em relação a povos tradicionais no que tange a direitos básicos de cidadania, principalmente através de saúde e educação diferenciadas enquanto reconhecimento de especificidades culturais, fortalece a tendência para o acionamento público de identidades étnicas nos contextos das Reservas Extrativistas ${ }^{279}$.

Para além do direito ao autorreconhecimento identitário conquistado nas últimas décadas, espera-se que as populações étnicas brasileiras possam desfrutar, em um futuro mais próspero, de condições materiais que permitam sua plena reprodução cultural, prestigiando-se e salvaguardando-se, assim, a pluralidade cultural que caracteríza o país.

279 REZENDE, Roberto Sanches. Gestão de Conflitos Territoriais Relacionados a Sobreposições de Terras Indígenas em Reservas Extrativistas na Amazômia (produto IV) Projeto PNUD BRA/08/002 Gestão de Reservas Extrativistas federais da Amazônia Brasileira. Pg, 25. 


\section{Cap. 7. Bibliografia}

ALMEIDA, Mauro W. Barbosa e REZENDE, Roberto Sanches. Uma Nota sobre Comunidades Tradicionais e Unidades de Conservação. Revista do Centro de Estudos Rurais - UNICAMP 2013. São Paulo. V. 7, n2.

ALlOGGIO, Tibério. Trinta anos da Flona do Tapajós: avanços e retrocessos na integração entre conservação e participação social. In, RICARDO, Fany (org.). Terras Indígenas \& Unidades de Conservação da natureza: o desafio das sobreposições. São Paulo: Instituto Socioambiental. 2004.

ANDERSON, Benedict: Comunidades Imaginadas. São Paulo. Cia das Letras, 2008. ARAÚJO, Ana Valéria. Terras Indígenas no Brasil: retrospectiva, avanços e desafios do processo de reconhecimento. In RICARDO, Fany (org.). Terras Indígenas \& Unidades de Conservação da natureza: o desafio das sobreposições. São Paulo: Instituto Socioambiental. 2004.

ARRUTI, José Maurício. Sobre Políticas de Reconhecimento e Sobreposições Territoriais. Revista do Centro de Estudos Rurais - UNICAMP 2013. São Paulo. V. 7, n2.

ATHIAS, Renato. A noção de identidade étnica na antropologia brasileira. De Roquette Pinto a Roberto Cardoso de Oliveira. Editora Universitária UFPE. Recife, PE. 2007.

BARTH, Frederik. Ethnic Groups and Boundaries. The Social Organization of Culture Difference. Waveland Press. 1969.

BIROLI, Flávia. Autonomia, opressão e identidades: a ressignificação da experiência na teoria política feminista. Revista Estudos Feministas, vol. 21, numero 1, 2013. UFSC.

BOURDIEU, P. ([1994] 1997). Razones prácticas - Sobre la teoría de la acción. Barcelona: Editorial Anagrama.

BRANCO, Carlos Manuel Martins. Etnicidade e Violencia Etnica. Revista Militar, novembro de 2006. 
BRANDÃO, CR. Identidade e Etnia. S. Paulo, Ed. Brasiliense, 1986.

CARDOSO, Fernando Henrique. Müller, Geraldo. Amazônia: expansão do capitalismo [online]. Rio de Janeiro: Centro Edelstein de Pesquisas Sociais, 2008.

CHACPE, Juliana Fernandes. Territórios Quilombolas e Unidades de Conservação de Proteção Integral: desafios da conciliação na Administração Federal. Dissertação de Mestrado. UNB 2014.

CHANDRA, Kanchan. Constructivist Theories of Ethnic Politics. 2012. Pg. 09. Disponível em: http://politics.as.nyu.edu/docs/IO/2587/Chapter1-Introduction-09-2810.pdf.

CORSTANGE, Daniel. Institutions and Ehnic Politics in Leanon and Yemen. University of Michigan. 2008.

COUTINHO JUNIOR, 2003, p. 52 apud REZENDE, Roberto Sanches \& POSTIGO, Augusto. Reconhecimentos Territoriais e Desconhecimentos Institucionais. Revista do Centro de Estudos Rurais - UNICAMP 2013. São Paulo. V. 7, n2.

D’AGOSTINI, S. et alii. Ciclo Econômico da Borracha - Seringueira Hevea Brasiliensis. Arg. (http://www.biologico.sp.gov.br/docs/pag/v9_1/dagostini3.pdf.

FAULHABER, Priscila. Participação indígena e preservação ambiental no Médio Solimões. In RICARDO, Fany (org.). Terras Indígenas \& Unidades de Conservação da natureza: o desafio das sobreposições. São Paulo: Instituto Socioambiental. 2004

FERREIRA, Walace. Justiça e reconhecimento em Nancy Fraser: interpretação teórica das ações afirmativas no caso brasileiro. Disponível em: http://www.cp2.g12.br/UAs/se/departamentos/sociologia/pespectiva_sociologica/Numer o4/Artigos/walla ce.pdf

FLYNN, Simone I. Relative Deprivation Theory. Sociology Reference Guide. Disponível em https://wiki.zirve.edu.tr/sandbox/groups/economicsandadministrativesciences/wiki/0edb 9/attachments/0d145/Flynn.pdf?sessionID=8940d4002f706e131a7b4041f136555e3b98 $\underline{37 \mathrm{~d} 4}$. 
FRANCISCO, Angelo Lima. Conflito Fundiário na Floresta nacional do Tapajós, in,FRASER, Nancy. Da redistribuição ao reconhecimento? Dilemas da justiça na era pós-socialista. Outledge, Nova York, 2006.

FREEMAN, Diane. An Explanation of Conflict: Ethnicity, Deprivation, and Rationalization. Kentucky Political Science Association Conference. 2015.

FURTADO, Celso. Formação Econômica do Brasil. 24 cd. São Paulo, Editora Nacional. GADELHA, Regina Maria A. Fonseca. Conquista e ocupação da Amazônia: a fronteira Norte do Brasil. Estud. av. [online]. 2002, vol.16, n.45.

GALVÃO, E. Índios e Brancos no Brasil, encontro de sociedades. Rio de Janeiro: Paz e Terra, 1979. apud ATHIAS, Renato. A noção de identidade étnica na antropologia brasileira. De Roquette Pinto a Roberto Cardoso de Oliveira. Editora Universitária UFPE. Recife, PE. 2007.

GEERTZ, Clifford. Primordial Loyalties and Standing Entities: Anthropological Reflections on the Politics of Identity. Public Lectures, No. 17.

GELLNER, Ernest (1964) Thought and Change, Londres, Weidenfeldand Nicolson, p. 168 citado em HUTCHINSON, 1994.

GÓIS, Pedro Manuel Rodrigues da Silva Madeira e. A construção secular de uma identidade étnica transnacional: a cabo-verdianidade. Tese de doutoramento. Universidade de Coimbra. Portugal. 2011. Disponível em https://estudogeral.sib.uc.pt/bitstream/10316/17848/1/tese\%20versão\%20final.pdf.

GURR, Ted. R. (1971).Why Men Rebel, New Jersey: Princeton University Press. 1971, Apud SALEH, Alam. Relative Deprivation Theory, Nationalism, Ethnicity and Identity Conclicts. Geopolitics Quarterly, Volume 8, n. 4, winter 2013. Pg. 165. Disponível em: http://www.sid.ir/en/VEWSSID/J_pdf/108020132807.pdf

HERRARTE, Gustavo. Identidade Étnica. Grupos étnicos y otros mitos sobre la etnicidade: interaccióon, cognición y una visión de etnicidad sin grupos étnicos. Revista de la Universidad del Valle de Guatemala. N. 16. 2006.

HOBSBAWN, Eric. Nations and Nationalism. Cambridge University Press. Cambridge, 1990. 
HOBSBAWM. Eric J. "Etnia e Nacionalismo na Europa de Hoje", In "Um Mapa da Questão Nacional”, organização Gopal Balakrishnan. Ed. Contraponto. 2000. Rio de Janeiro, RJ. pg 272.

LIMA, Deborah de Magalhães. As sobreposições em Mamirauá e a necessidade de um novo pacto institucional. RICARDO, Fany (org.). Terras Indígenas \& Unidades de Conservação da natureza: o desafio das sobreposições. São Paulo: Instituto Socioambiental. 2004.

LOBÃO. Ronaldo Joaquim da Silveira. Cosmologias Políticas do Neocolonialismo: como uma política pública pode se transformar em uma política do Ressentimento. Tese de Doutorado apresentada ao Programa de Pós-Graduação em Antropologia Social da UNB. 2006, p. 372006.

MAYBURY-LEWIS, David. Identidade Étnica em Estados Pluriculturais. In: Scott, Parry \& Zarur, George (org) Identidade, Fragmentação e Diversidade na América Latina. Recife. Ed. Universitária. 2003.

MARETTI, Cláudio. Conservação e valores. Relações entre áreas protegidas e indígenas: possíveis conflitos e soluções. In: In: RICARDO, Fany (org.). Terras Indígenas \& Unidades de Conservação da natureza: o desafio das sobreposições. São Paulo: Instituto Socioambiental-ISA. 2004.

MARX, Karl e ENGELS, Friedrich (1977), Collected Works, London, Laurence and Wishart.

MONTES, Maria Lúcia. Raça e Identidade: entre o espelho, a invenção e a ideologia. In: SCHWARCZ, L. M. \& QUEIROZ, Renato Silva (orgs.) Raça e Diversidade. São Puao: EDUSP, 1996.

MORO, Javier. Caminhos de Liberdade: A luta pela defesa da Selva. Ed. Planeta. Sao Paulo, SP. 2011.

NASCIMENTO, Paulo César "Dilemas do nacionalismo" Revista Brasileira de Informação Bibliográfica em Ciências Sociais (BIB) 56. São Paulo: ANPOCS, 2003.

NÓBREGA. Terezinha Petrucia. "Corpo, percepção e conhecimento em Merleau-Pontu. Estudos de Psicologia, 2008. UFRN. 
OLIVEIRA, Roberto Cardoso de. Identidade, Etnia e Estrutura Social. São Pualo: Pioneira, 1976.

OLIVEIRA, João Pacheco (org.). Etnicidade, política e reelaboração cultural no Nordeste indígena. Rio de Janeiro: Contra Capa Livraria/LACED, 2004.

PANTOJA, Mariana C., COSTA, E. M. L \& ALMEIDA, M. W. B. de 'Teoria e prática da etnicidade no Alto Juruá Acreano. Revista Raízes, v.31, 2011.

PHILLIPS, Anne. Multiculturalism without Culture. Princeton: Princeton University Press, 2007.

PIMENTA. José. Indigenismo e Ambientalismo na Amazônia occidental: a propósito dos Ashaninka do rio Amônia. Revista de Antropologia, São Paulo, USP, 2007, v. 50 n. 2. Disponível on-line em: http://www.revistas.usp.br/ra/article/viewFile/27274/29046.

REIS, Marise. Terra Indígena Porto praia alternativa de posse de território e resistência à ordem socioambiental na RDS Mamirauá. In RICARDO, Fany (org.). Terras Indígenas \& Unidades de Conservação da natureza: o desafio das sobreposições. São Paulo: Instituto Socioambiental. 2004. Pg. 551.

REZENDE, Roberto Sanches. Gestão de Conflitos Territoriais Relacionados a Sobreposições de Terras Indígenas em Reservas Extrativistas na Amazômia (produto IV) Projeto PNUD BRA/08/002 - Gestão de Reservas Extrativistas federais da Amazônia Brasileira.

REZENDE, Roberto Sanches. Gestão de Conflitos Territoriais Relacionados a Sobreposições de Terras Indígenas em Reservas Extrativistas na Amazômia (produto IV) Projeto PNUD BRA/08/002 - Gestão de Reservas Extrativistas federais da Amazônia Brasileira.

RIBEIRO, Darcy. Teoria do Brasil. Rio de Janeiro: Paz e Terra, 1972.

RICARDO, Fany (org.). Terras Indígenas \& Unidades de Conservação da natureza: o desafio das sobreposições. São Paulo: Instituto Socioambiental. 2004.

RUCIMAN, W. G. Relative Deprivation and Social Justice, Londres, Routledge et Kegan Paul. 1966. Apud. VALA, Jorge; LIMA, Maria Luísa \& MONTEIRO, Maria Benedicta. Conflitos intergrupais em contexto organizacional: problemas de investigação e de intervenção - estudo de um caso. Análise Sociaal, vol. XXIII (99), 
1987-5,

801-814.

Disponível

em:

http://analisesocial.ics.ul.pt/documentos/1223028279U3eRE3ni0Qn02JI5.pdf

SALEH, Alam. Relative Deprivation Theory, Nationalism, Ethnicity and Identity Conflicts. Geopolitics Quarterly, Vol. 8.

SANTILLI, Juliana. Socioambientalismo e Novos Direitos. Proteção juridical à diversidade biológica e cultural. IEB. São Paulo: 2005.

SANTOS, Edson Vanda Pereira dos Santos. "Diálogos, Práticas e Espaços Participativos: A Participação da Comunidade da Reserva Extrativista CazumbáIracema/Acre no Programa Biodiversidade Brasil-Itália. Dissertação de Mestrado . UFRRJ. 2007

SMITH, Antony. The Ethnic Revival in the Modern World. Cambridge University Press. 1981 The Etnic Revival - Antony D. Smith. Pg. 28.

SMITH, Anthony. O Nacionalismo e os Historiadores. In. Gopal Balakrishnan (org.) Um Mapa da Questão Nacional. Contraponto: Rio de Janeiro. 2000.

SMITH, Anthony. The Antiquity of Nations. Wiley, 2004.

SOUSA, Carlos Jorge dos Santos. Relações Interétnicas, Dinâmicas Sociais e Estratégias Identitárias de uma Família Cigana Portuguesa - 1827-1957. Universidade Aberta. Tese de Doutoramento. Março de 2010.

SOUSA, Ivo Carneiro de. Etnicidade e Nacionalismo: Uma proposta de quadro teórico. Africana Studia. N. 1, 1999. Portugal.

SOUZA, Marina Oliveira e Souza. Passar para Indígena - na Reserva de Desenvolvimento Sustentável Amanã (AM). Dissertação de mestrado. UFMG. Belo Horizonte. 2011.

STOUFFER, Samuel A. The American Soldier (1949), volume da coletanea Studies in Social Psychology in WWII.

VAZ FILHO. As Comunidades Munduruku na Flona do Tapajós. RICARDO, Fany (org.). Terras Indígenas \& Unidades de Conservação da natureza: o desafio das sobreposições. São Paulo: Instituto Socioambiental. 2004. 
VERAS, Marcos Flávio Portela \& DE BRITO, Vanderli Guimarães. "Identidade Étnica: A dimensão política de um processo de reconhecimento. ANTROPOS Revista de Antropologia, Ano 4, Volume 5, maio de 2012.

WALLERSTEIN, Immanuel. The modern world-system. Capitalist agriculture and the origins of the Europena world-economy in the 16th. Century. New York, Academic Press, 1974.

WEBER, Max. Economia e Sociedade. V.I. Brasília: Editora Universidade de Brasília, 1991.

WEBER, Max (2000) [1915-1921]. "Relações Comunitárias Étnicas". In: Economia e Sociedade. Vol. 1. Brasília: Editora da UNB.

WEBER, Max. Metodologia das Ciências Sociais, Parte 2. Tradução Augustin Wernet; Introdução à edição brasileira Maurício Tragtenberg. São Paulo: Cortez; Campinas, SP: Editora da Universidade Estadual de Campinas, 1992.

REZENDE, Roberto Sanches \& POSTIGO, Augusto. Reconhecimentos Territoriais e Desconhecimentos Institucionais. Revista do Centro de Estudos Rurais - UNICAMP 2013. São Paulo. V. 7, n2. 